
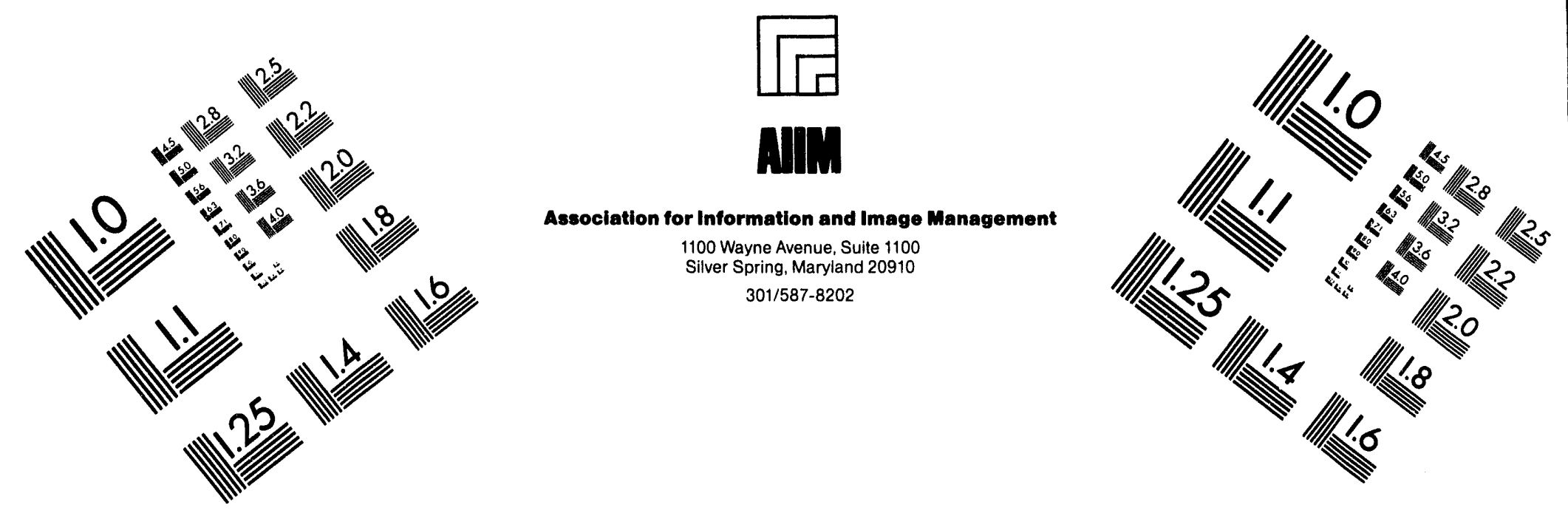

Centimeter

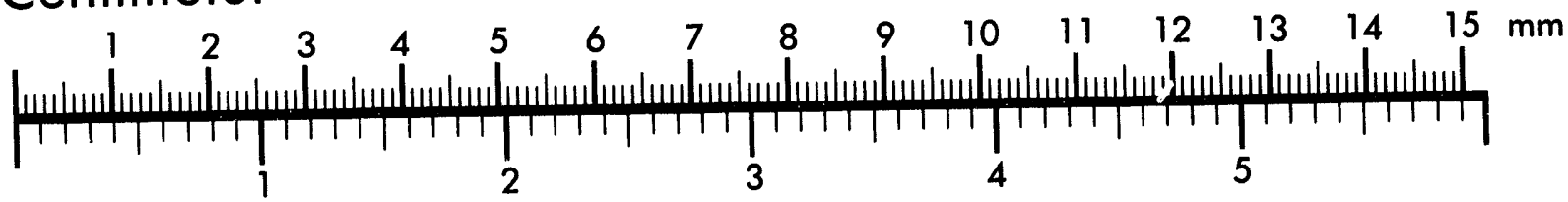
Inches
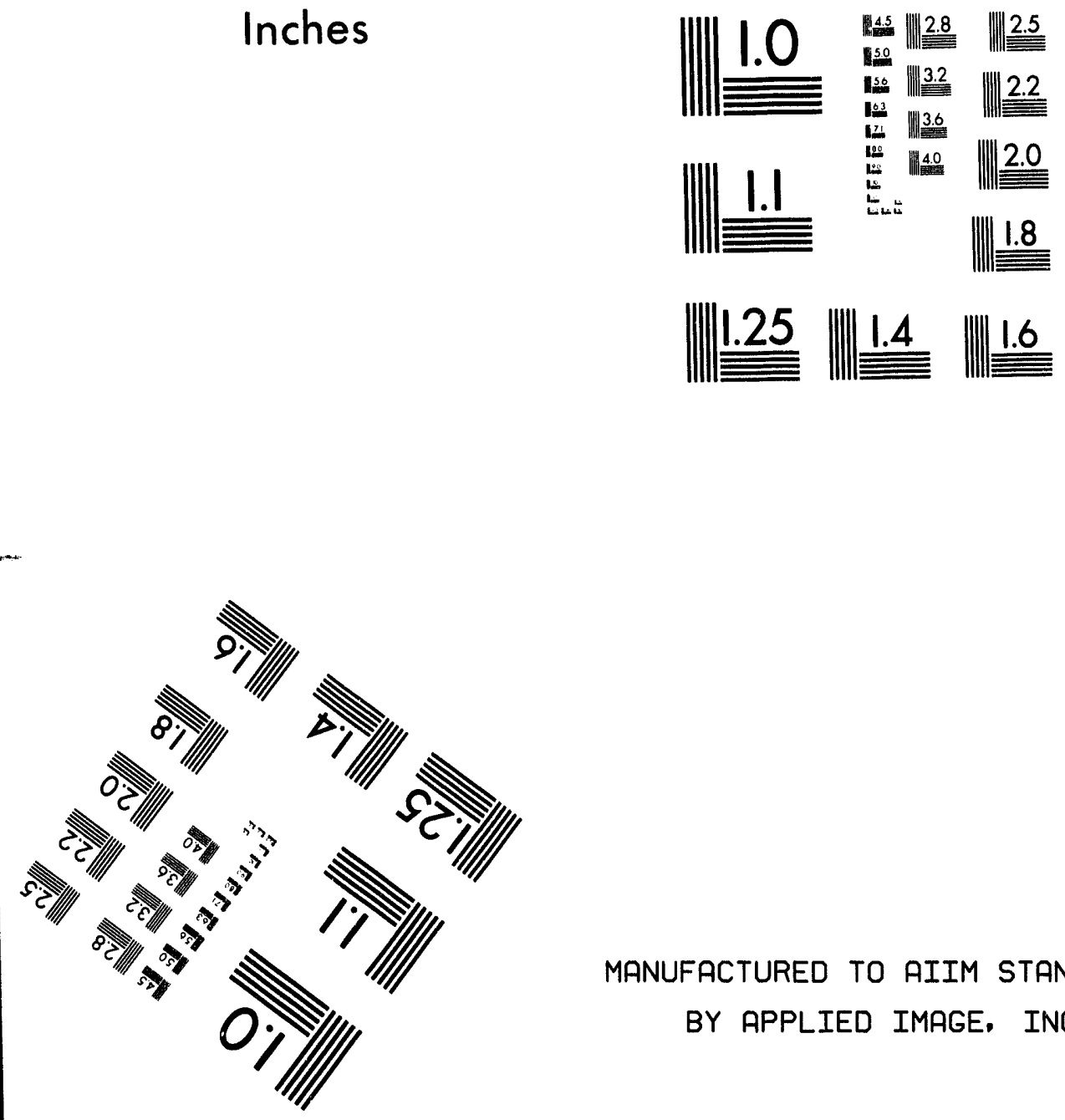

MANUFACTURED TO AIIM STANDARDS

BY APPLIED IMAGE, INC.

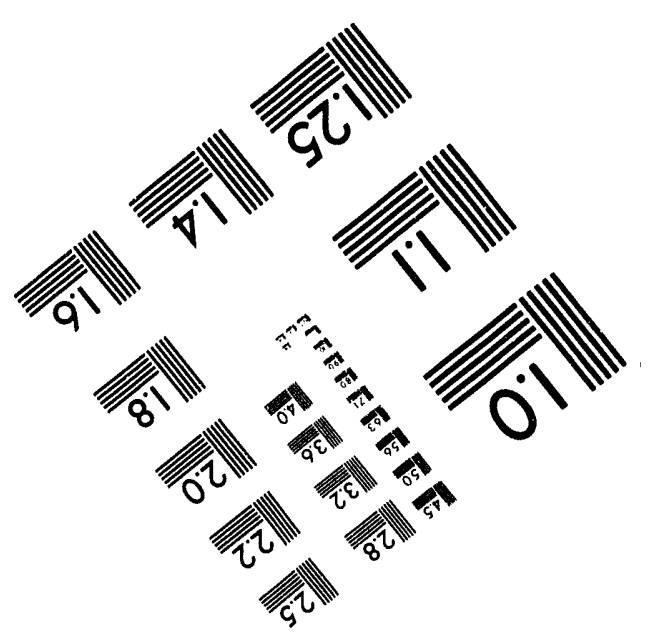





\title{
Preliminary Hazards Analysis
}

\section{Vitrification Processes}

\author{
Prepared under the direction of \\ Richard C. Ragaini \\ Lawrence Livermore National Laboratory \\ Environmental Restoration \& Waste Management \\ Applied Technology Program \\ by \\ D. Coordes \\ M. Ruggieri \\ J. Russell \\ W. TenBrook \\ P. Yimbo \\ Science Applications International Corporation \\ 4900 Hopyard Road, Suite 310 \\ Pleasanton, CA 94588
}

June 1994

Prepared for the

Mixed Waste Integrated Program

U.S. Department of Energy

Office of Technology Development

Washington, DC 20585

under Lawrence Livermore National Laboratory

Contract B160602 


\section{TABLE OF CONTENTS}

1.0 EXECUTIVE SUMMARY $1-1$

2.0 APPLICABLE STATUTES, RULES, AND DEPARTMENTAL ORDERS. $2-1$

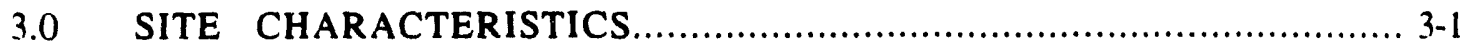

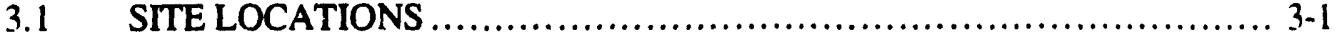

3.1.1 Kansas City Plant .............................................. 3-1

3.1.2 Los Alamos National Laboratory............................... 3-1

3.1.3 Mound Laboratory ............................................ 3-2

3.1.4 Pantex Plant.................................................... 3-2

3.1.5 Rocky Flats Plant........................................................ 3-3

3.1.6 Sandia National Laboratories, New Mexico ...................... 3-3

3.1.7 Sandia National Laboratories, California................................ 3-3

3.1.8 Pinellas Plant ........................................................ 3-3

3.1.9 Argonne National Laboratory, East ............................. 3-3

3.1.10 Argonne National Laboratory, West ........................... 3-3

3.1.11 Brookhaven National Laboratory.................................... 3-3

3.1.12 Idaho National Engineering Laboratory............................... 3-4

3.1.13 Feed Materials Production Center, Fernald ..................... 34

3.1.14 Oak Ridge National Laboratory, including X-10, K-25 and $\mathrm{Y}-12$ Sites ................................................. 34

3.1.15 Paducah Gaseous Diffusion Plant .............................. 3-4

3.1.16 Portsmouth Gaseous Diffusion Plant ............................... 3-4

3.1.17 Nevada Test Site............................................................ 34

3.1.18 Hanford Project Site ............................................ 3-5

3.1.19 Lawrence Berkeley Laboratory .................................. 3-5

3.1.20 Lawrence Livermore National Laboratory Including Site $300 \ldots \ldots . .3-5$

3.1.21 Energy Technology and Engineering Center, Santa Susanna ......... 3-5

3.1.22 Stanford Linear Accelerator Center................................... 3-5

3.1.23 Savannah River Plant .............................................. 3-6

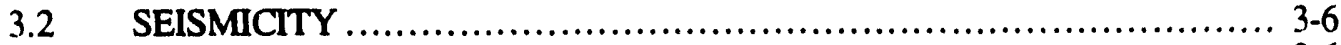

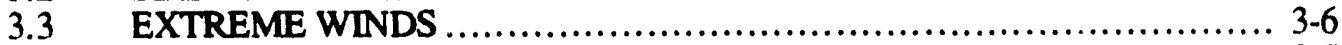

3.4 FLOODING .................................................................. 3-7

3.5 TRANSPORTATION AND UTILITIES ................................. $3-10$

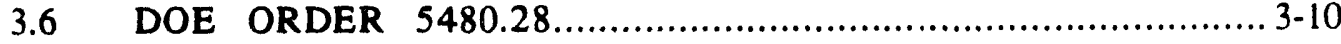

4.0 FACILITY DESCRIPTION AND OPERATIONS $\ldots \ldots \ldots \ldots \ldots \ldots \ldots \ldots \ldots \ldots \ldots, 4$

4.1 LOCATION AND DESCRIPTION ....................................... 4

4.1.1 Site Location .................................................. 4-1

4.1.2 General Building Requirements............................................. 4-1

4.1.3 Building Design Requirements ............................... 4-2 


\section{TABLE OF CONTENTS (Continued)}
4.2 GENERAL DESCRIPTION OF OPERATIONS $\ldots \ldots \ldots \ldots \ldots \ldots \ldots \ldots \ldots, 4$
4.2.1 System Description............................................ 4-3
4.2.2 Process Description ............................................. 4-5
4.2.3 Required Support Equipment ..................................... $4-6$
4.3 DESIGN REVIEW.................................................. 4 -6
4.3.1 Safety Significant Structures ................................ 4-6
4.3.2 Structures and Containers ........................................ 4-7

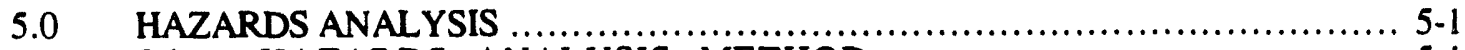

5.1 HAZARDS ANALYSIS METHOD .................................... 5-1

5.2 INVENTORIES ............................................................ 5-10

5.3 BOUNDING ANAL YSES OF POTENTIAL ACCIDENTS ................ $5-20$

5.3.1 Operational and Equipment Assessment ...........................5-22

5.3.2 Radiological Assessment ........................................ 5-25

5.4 CONSEQUENCE ANALYSIS AND PRELIMINARY HAZARD

CLASSIFICATION ....................................................5 5-29

5.4 .1 Consequences of Radiological Assessments......................... 5-30

5.4.2 Consequences of Hazardous Material Assessments..................... 5-30

5.4 .3 Conclusions................................................... 5-30

6.0 REFERENCES......................................................... 6-1

APPENDIX A HOTSPOT Calculations .......................................... A-1

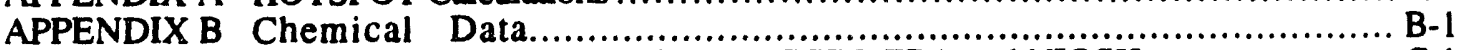

APPENDIX C Definitions from AIHA, OSHA, ACGIH, EPA and NIOSH...............

\section{LIST OF TABLES AND FIGURES}

Table 2-1. Other Applicable Federal Requirements.................................. 2-4

Table 2-2. Applicable DOE Orders ...................................................... 2-7

Table 2-3. Requirements for Process Safety Management ............................. 2-10

Table 3-1. Maximum Potential Source-Receptor Isolation for DOE Sites .................. 3-2

Table 3-2. Horizontal Ground Motion Criteria and Annual Probability of Exceedance at DOE Sites ................................................... 3-7

Table 3-3. Recommended Design Wind and Tomado Speed Criteria

and Annual Probability of Exceedance at DOE Sites ............................ 3-8

Table 3-4. Mean Flood Hazard Evaluation Criteria and Annual Probabilities of Exceedance for DOE Sites.................................................................... 3-9

Table 3-5. DOE 5480.28 Performance Criteria ...................................... 3-11

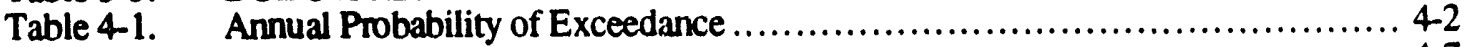

Table 4-2. Types of Mixed Waste Containers $\quad$............................................... 4

Table 5-1. Potential Hazard Sources ...................................................... 5-3

Table 5-2. Hazards Characterization: Vitrification Processes........................... 5-5

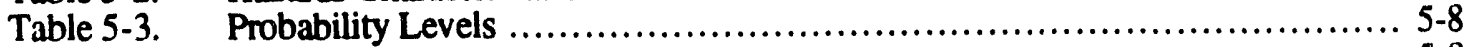

Table 5-4. Consequence Levels ...................................................... $5-8$

Table 5-5. Proposed Maximum Radionuclide Inventory for

Table 5-6. Proposed Maximum Radionuclide Inventory for a Category 3 Facility $\quad . \ldots \ldots \ldots 5-11$

Table 5-7. DOE Mixed Waste Composition by Type ................................. 5-14 


\section{TABLE OF CONTENTS (Continued)}

Table 5-8. Mixed Waste Treatment Project Waste Stream Categories

Selected for Surrogate Formulations

Table 5-9. Content of Selected Surrogate Waste Streams................................... $5-17$

Table 5-10. Radioactive Material Category 3 Release Factors. Source Terms, and Doses... .5-27

Table 5-11. Radioactive Material Category 2 Release Factors, Source Terms, and Doses...5-27

Table 5-12. Waste Fire Accident Results..............................................5-29

Figure 4-1. Vitrification Prototypes.............................................. 4-5

Figure 5-1. Hazard Analysis Process................................................. 5-2

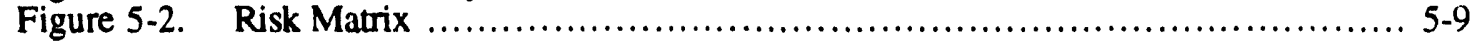




\subsection{EXECUTIVE SUMMARY}

Joule heating technologies, utilize an electrical current which is passed through a melt material providing a source of resistive heat. A future mixed waste vitrification system utilizing joule heating technologies may be similar to demonstration systems currently under study at Clemson University Environmental Systems Engineering Research Laboratory in associated with the Westinghouse Savannah River Company.

This Preliminary Hazards Analysis (PHA) for mixed waste vitrification by joule heating is performed in accordance with the requirements of United States Department of Energy (DOE) Orders 5480.23, DOE Order 5480.21, DOE Order 5480.22, DOE Order 5481.1B, and the guidance provided in DOE Standards DOE-STD-1027-92. Consideration is given to the proposed regulations published as 10 CFR 830 and DOE Safety Guide SG 830.110 .

The purpose of performing a PHA is to establish an initial hazard categorization for a DOE nuclear facility and to identify those processes and structures which may have an impact on or be important to safety. The PHA is typically performed during and provides input to project conceptual design. The PHA is then followed by a Preliminary Safety Analysis Report (PSAR) performed during Title I and II design. The PSAR then leads to performance of the Final Safety Analysis Report performed during the facility's construction and testing. It should be completed before routine operation of the facility commences.

This PHA addresses the first four chapters of the safety analysis process, in accordance with the requirements of DOE Safety Guidelines in SG 830.110:

- Section 2.0 identifies the statutes, rules, and DOE Orders applicable to methods and content of this PHA. DOE Order 5480.23, Nuclear Safety Analysis Reports, and proposed rule 10 CFR 830.110 "Nuclear Safety Management." describe the content requirements for the hazards analysis and preliminary classification of a DOE nuclear facility.

- Section 3.0 provides information on natural phenomena and surrounding activities which may affect the safe operation of a facility at major DOE Complex sites. Natural features include site geography, seismicity, meteorology, and surface waters. Manmade features such as transportation systems, land use pattems, and population distributions are discussed.

- Section 4.0 details some of the facility design characteristics important to a future facility that can impact site selection. Although the process is not affected by the location, the environmental characteristics of potential sites can have a significant impact on the design and construction of the facility. This section provides the context for the hazards characterization table in Section 5. 
- Section 5.0 describes the various hazard energy sources, the event initiators. anticipated design and administrative measures to prevent or mitigate accidents. potential impacts of worst case accidents, and the method used to identify hazards. analyze events, and determine consequences. Postulated maximum inventories of hazardous and radioactive materials are used to establish the preliminary facility hazard classification. The basic hazards associated with energy sources and materials which may be present in the facility and the bounding accident scenarios are discussed and analyzed. The consequences of these maximum release accident scenarios are enumerated and are used to verify the preliminary facility hazard classification.

The hazards associated with vitrification processes are evaluated using standard safety analysis methods which include: identification of credible potential hazardous energy sources; identification of preventative features of the facility or system; identification of mitigative features; and analyses of credible hazards. Maximal facility inventories of radioactive and hazardous materials are postulated to evaluate worst case accident consequences. These inventories were based on DOE-STD-1027-92 guidance and the surrogate waste streams defined by Mayberry, et al. Radiological assessments indicate that a facility, depending on the radioactive material inventory, may be an exempt. Category 3, or Category 2 facility. The calculated impacts would result in no significant impact to offsite personnel or the environment. Hazardous materials assessment indicates that a Mixed Waste Vitrification facility will be a Low Hazard facility having minimal impacts to offsite personnel and the environment. 


\subsection{APPLICABLE STATUTES, RULES, REgUlATIONS, AND DEPARTMENTAL ORDERS}

This section identifies the statutes, rules, regulations, and DOE Orders applicable to the safety basis of any future vitrification facility or integrated facility for the treatment of DOE mixed waste. DOE Order 5480.23, Attachment 1, Section 4.f.(3)(d), Item 5 (DOE 1992a), describes the content requirements for the hazards analysis and preliminary classification of a DOE nuclear facility. Content requirements include a description and inventory of all hazardous materials, including radioactive materials; identification of energy sources which may cause material release; bounding analyses of potential releases; and the hazard classification for all major types of hazards and the facility as-a-whole. Current technical guidance for each area is provided. Proposed rule 10 CFR 830.110 (DOE 1993a) and Proposed DOE Standard DOE-STD-SAFT-0019 (DOE 1993e), Guidance for Preparation of DOE 5480.22 (TSR) and DOE 5480.23 (SAR) Implementation Plans, were considered in the preparation of this PHA although the proposed regulations and draft guidance document have not been approved.

\section{SCOPE AND CONTENT OF HAZARDS ANALYSIS}

DOE 5480.23, Nuclear Safety Analysis Reports (DOE 1992a) Draft.

10 CFR 830.110 (Proposed Rule), Safety Analysis Report (DOE 1993a).

DOE SG 830.110, Guidelines for the Preparation of Safety Anatysis Reports for DOE Nuclear Facilities and Nonfacility Nuclear Operations (DOE 1991b) Draft.

DOE Order 5481.1B, Safety Analysis and Review System (DOE 1986).

\section{INVENTORY OF HAZARDOUS MATERIALS, INCLUDING RADIOACTIVE MATERIALS}

DOE-STD-1027-92, Hazard Categorization and Accident Analysis Techniques for Compliance with DOE Order 5480.23, Nuclear Safety Analysis Reports (DOE 1992b).

Environmental Protection Agency (EPA), Federal Energy Management Agency, and Department of Transportation (DOT); Technical Guidance for Hazards Analyses. Emergency Planning for Extremety Hazardous Substances (1987).

Department of Labor. Title 29, Code of Federal Regulations, Part 1920.119. "Process Safety Management of Highly Hazardous Chemicals," Washington, DC (DOL 1993).

Environmental Protection Agency (EPA), "Emergency Planning and Notification," Title 40. Code of Federal Regulations, Part 355. Washington, DC (EPA 1993).

\section{ENERGY SOURCES AND PERSONNEL HAZARD SOURCES}

UCRL-15910, Design and Evaluation Guidelines for Department of Energy Facilities Subjected to Natural Phenomena Hazards (Kennedy et al. 1990). 
Department of Energy (1992d). DOE Standard - Natural Phenomena Hazards Performance Categorization Criteria for Structures, Systems, and Components, DOE, Washington. DC. DOE-STD-1021-92.

Department of Energy (1992e), DOE Standard - Guidelines for Use of Probabilistic Seismic Hazard Curves at Department of Energy Sites, DOE, Washington, DC, DOE-STD1024-92, December.

Department of Energy (1993c), DOE Standard - Natural Phenomena Hazards Site Characterization Criteria, DOE, Washington, DC, DOE-STD-1022,92, April 1993 DRAFT.

Department of Energy (1993d), DOE Standard - Natural Phenomena Hazards Assessment Criteria, DOE, Washington, DC, DOE-STD-1023-92, April 1993 DRAFT.

Department of Energy (1993f), DOE Standard - Natural Phenomena Hazards Design and Evaluations Criteria for Department of Energy Facilities, DOE, Washington, DC. DOESTD-1020-92, February 1993 DRAFT.

DOE 5480.28, Natural Phenomena Hazards Mitigation, (DOE 1993b)

\section{BOUNDING ANALYSES OF POTENTIAL RELEASES OF HAZARDOUS AND RADIOACTIVE MATERIAL}

DOE-STD-1027-92, Hazard Categorization and Accident Analysis Techniques for Compliance with DOE Order 5480.23, Nuclear Safety Analysis Reports (DOE 1992b).

LA-10294-MS/UC-41, A Guide to Radiological Accident Considerations for Siting and Design of DOE Nonreactor Nuclear Facilities (Elder et al. 1986)

Environmental Protection Agency (EPA), Federal Emergency Management Agency, and Department of Transportation (DOT), Technical Guidance for Hazards Analyses, Emergency Planning for Extremely Hazardous Substances (1987).

NUREG-1320, Nuclear Fuel Cycle Accident Anatysis Handbook (Ayer et al. 1988).

DOE/EH-0071, Internal Dose Conversion Factors for Calculation of Dose to the Public (DOE 1988d).

DOE/EH-0070, External Dose Conversion Factors for Calculation of Dose to the Public (DOE 1988c).

\section{FACILITY HAZARD CLASSIFICATION}

DOE-STD-1027-92, Hazard Categorization and Accident Analysis Techniques for Compliance with DOE Order 5480.23, Nuclear Safety Analysis Reports (DOE 1992b).

DOE 5481.1B, Safery Analysis and Review System (DOE 1986).

DOE 5480.23, Nuclear Safety Analysis Reports (DOE 1992a).

10 CFR 830.110, Safety Analysis Report (DOE 1993a).

DOE SG 830.110, Guidelines for the Preparation of Safety Analysis Reports for DOE Nuclear Facilities and Nonfacility Nuclear Operations (DOE 1991b) Draft. 
The statutes, rules, and DOE Orders applicable to a mixed waste treatment facility are listed in Tables 2-1 and 2-2. The state and local statutes, ordinances, and other requirements should also be included when a specific physical site is identified and when those requirements could establish safety constraints on a potential future vitrification facility. The tables provide a cross reference to the applicable chapters of a future facility Safety Analysis Report (SAR) where these requirements should be discussed.

Title 29 CFR 1910.119 (DOL 1993) requires implementation of a Process Safety Management program for operations that use hazardous chemicals in excess of the threshold quantities of 29 CFR 1910.119, Appendix A. and pressurized flammables in excess of 10,000 pounds. The program requirements should emphasize prevention of catastrophic releases of such materials and mitigation of consequences if such releases occur. These may apply to a future vitrification facility.

A vitrification facility process safety management program, if required, should include provisions to plan and document worker participation in responding to the requirements, including review of information developed pursuant to the program requirements. The required information includes chemical safety information, process technical descriptions and specifications, process hazards analyses, operating procedures, operational limits, safety system functions, training programs, and pre-startup safety reviews.

The program should include provisions to assure the continuing safety of critical process components. These program elements include maintenance procedures, maintenance training, inspection and testing provisions, methods to document and correct deficiencies, and quality assurance.

The program should contain provisions to prevent accidents during operation or to mitigate accidents should they occur. These should include hot-work permitting, process change control, investigation of incidents, emergency planning and response, and audits of compliants pertaining to the process safety management program. Table 2-3 presents the major elements of $10 \mathrm{CFR}$ 1910.119 and appropriate cross-references to the chapter where the elements should be discussed in the future facility SAR.

Further detail conceming the regulatory requirements that must be met by an integrated mixed waste treatment facility are contained in BHARC-800/92/005, Regulatory Requirements for Deploying Integrated Demonstration Technologies (Frahm et al., 1992). 
Table 2-1. Other Applicable Federal Requirements

\begin{tabular}{|c|c|c|c|}
\hline $\begin{array}{c}\text { Statutel } \\
\text { Regulation }\end{array}$ & Title & $\begin{array}{l}\text { Description } \\
\end{array}$ & $\begin{array}{l}\text { Applicable } \\
\text { SAR Chapter }\end{array}$ \\
\hline 10 CFR 835 & $\begin{array}{l}\text { Radiation Protection for } \\
\text { Occupational Workers }\end{array}$ & $\begin{array}{l}\text { Establishes radiation protection standards, limits, and program requirements for } \\
\text { protecting workers and other persons from ionizing radiation at DOE facilities. }\end{array}$ & 9 \\
\hline 10 CFR Part 1021 & $\begin{array}{l}\text { Compliance with the National } \\
\text { Environmental Policy Act }\end{array}$ & $\begin{array}{l}\text { protecting workers and other persons from lonize } \\
\text { Establishes requirements for performance of environmental assessments. }\end{array}$ & 7 \\
\hline 10 CFR 1022 & $\begin{array}{l}\text { Compliance with } \\
\text { Floodplain/Wetlands Environmental } \\
\text { Review Requirements }\end{array}$ & Establishes requirements for floodplain/wetlands environmental reviews. & 7 \\
\hline 29 CFR 1910,1926 & $\begin{array}{l}\text { Occupational Safety and Health } \\
\text { Administration (OSHA) Standards }\end{array}$ & $\begin{array}{l}\text { Establishes worker safety provisions. All industrial safety and construction } \\
\text { operations shall comply with the applicable OSHA requirements. }\end{array}$ & 17 \\
\hline 40 CFR 50 & $\begin{array}{l}\text { National Ambient Air Quality } \\
\text { Standards }\end{array}$ & operations shall comply with the applicable & 10 \\
\hline 40 CFR 58 & Ambient Air Quality Surveillance & $\begin{array}{l}\text { Establishes criteria and requirements for ambient air quality monitoring and for } \\
\text { reporting ambient air quality data and information. }\end{array}$ & 10 \\
\hline 40 CFR 60 & $\begin{array}{l}\text { Standards of Performance for New } \\
\text { Stationary Sources }\end{array}$ & $\begin{array}{l}\text { reporting ambient air quality data and inromition. } \\
\text { Establishes pollution standards for any new stationary pollutant source. }\end{array}$ & 10 \\
\hline 40 CFR 61 & $\begin{array}{l}\text { National Emissions Standard for } \\
\text { Hazardous Air Pollutants (NESHAPS) }\end{array}$ & $\begin{array}{l}\text { Establishes air emission standards. All airborne radiological and hazardous } \\
\text { constituents shall comply with requirements of NESHAPS. }\end{array}$ & 7 \\
\hline 40 CFR 116 & Designation of Hazardous Substances & $\begin{array}{l}\text { Designates hazardous substances under Section } 311(\mathrm{~b})(2)(\mathrm{A}) \text { of the Federal Water } \\
\text { Pollution Control Act. }\end{array}$ & 7 \\
\hline 40 CFR 117 & $\begin{array}{l}\text { Determination of Reportable } \\
\text { Quantities of Hazardous Substances }\end{array}$ & $\begin{array}{l}\text { Pollution Control Act. } \\
\text { Designates the amount of a release of a hazardous substance defined in } 40 \text { CFR } 116 \\
\text { which is considered to be reportable. }\end{array}$ & 19 \\
\hline 40 CFR 122 & $\begin{array}{l}\text { EPA Administered Permit Programs: } \\
\text { National Pollution Discharge } \\
\text { Elimination System (NPDES) }\end{array}$ & $\begin{array}{l}\text { which is considered to be raportable. } \\
\text { Establishes permitting requirements for the discharge of pollutants from point } \\
\text { sources into U.S. Waters. }\end{array}$ & 7 \\
\hline 40 CFR 125 & Criteria and Standards for NPDES & $\begin{array}{l}\text { Establishes criteria and standards for imposing technology-based treatment } \\
\text { requirements; permit issuance to aquaculture projects; compliance date extensions } \\
\text { for installing innovative technology; water quality variance grants; secondary } \\
\text { treatment requirement modifications; sewage sludge disposal; ocean discharge; } \\
\text { best management practices; and alternative effluent limitations. }\end{array}$ & 7 \\
\hline 40 CFR 129 & Toxic Pollutant Effluent Standards & Establishes effluent standards or prohibitions for toxic pollutants & 7 \\
\hline 40 CFR 191 & $\begin{array}{l}\text { Environmental Radiation Protection } \\
\text { Standards for Management and } \\
\text { Disposal of Spent Nuclear Fuel, High- } \\
\text { Level, and Transuranic Radioactive } \\
\text { Wastes }\end{array}$ & $\begin{array}{l}\text { Designates radiation dose guidelines for the public resulting from inanagement and } \\
\text { storage of spent nuclear fuel, high-level waste, or transuranic waste al facilities } \\
\text { operated by DOE. }\end{array}$ & 9 \\
\hline 40 CFR 241 & $\begin{array}{l}\text { Guidelines for the Land Disposal of } \\
\text { Solid Wastes }\end{array}$ & $\begin{array}{l}\text { Gives applicable guidelines for the land disposal of all solid wastes and outlines } \\
\text { minimum levels of performance required of any solid wasle disposal site operator. }\end{array}$ & 7 \\
\hline
\end{tabular}


Table 2-1. Other Applicable Federal Requirements (Continued)

\begin{tabular}{|c|c|c|c|}
\hline $\begin{array}{c}\text { Statutel } \\
\text { Regulation }\end{array}$ & Title & $\begin{array}{l}\text { Description } \\
\end{array}$ & $\begin{array}{l}\text { Applicable } \\
\text { SAR Chapter }\end{array}$ \\
\hline 40 CFR 260 & $\begin{array}{l}\text { Hazardous Waste Management } \\
\text { System: General }\end{array}$ & $\begin{array}{l}\text { Provides general standards and overview information applicable to the Resource } \\
\text { Conservation and Recovery Act (RCRA). }\end{array}$ & 7 \\
\hline 40 CFR 261 & $\begin{array}{l}\text { Identification and Listing of } \\
\text { Hazardous Waste }\end{array}$ & $\begin{array}{l}\text { Conservation and Recovery } A c t(R C K A) \text {. } \\
\text { Identifies solid wastes subject to regulation as hazardous wastes. }\end{array}$ & 7 \\
\hline 40 CFR 262 & $\begin{array}{l}\text { Standards Applicable to Generators of } \\
\text { Hazardous Waste }\end{array}$ & $\begin{array}{l}\text { Establishes standards for generators of hazardous waste for recordkeeping, } \\
\text { reporting, exporting, importing, and pretransportation. }\end{array}$ & 7 \\
\hline 40 CFR 263 & $\begin{array}{l}\text { Standards Applicable to Transporters } \\
\text { of Hazardous Waste }\end{array}$ & 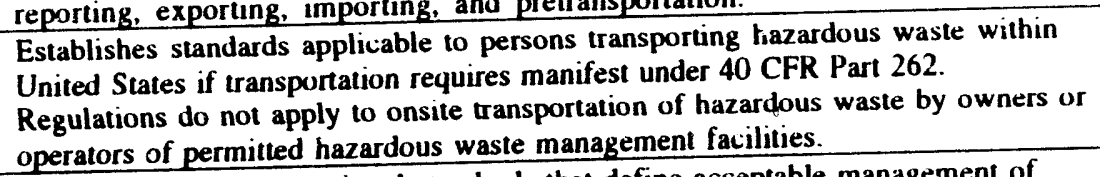 & 7 \\
\hline 40 CFR 264 & $\begin{array}{l}\text { Standards for Owners and Operators of } \\
\text { Hazardous Waste Treatment, Storage, } \\
\text { and Disposal Facilities }\end{array}$ & $\begin{array}{l}\text { Establishes minimum national standards that define acceptable management of } \\
\text { hazardous waste. }\end{array}$ & 7 \\
\hline 40 CFR 265 & $\begin{array}{l}\text { Interim Status Standards for Owners } \\
\text { and Operators of Hazardous Waste } \\
\text { Treatment, Storage, and Disposal } \\
\text { Facilities }\end{array}$ & $\begin{array}{l}\text { Establishes minimum national standards that define acceptable management of } \\
\text { hazardous waste during periods of interim status and until certification of final } \\
\text { closure or, if facility is subject to postclosure requirements, until postclosure } \\
\text { responsibilities are fulfilled. }\end{array}$ & 7 \\
\hline 40 CFR 268 & Land Disposal Restriction & $\begin{array}{l}\text { Iesponsibilities are fultilled. } \\
\text { circumstances under which an otherwise prohibited waste may continue to be land } \\
\text { disposed. Requirements apply to persons who generate or transport hazardous } \\
\text { waste and owners and operators of hazardous waste treatment, storage, and } \\
\text { disposal facilities. }\end{array}$ & 7 \\
\hline 40 CFR 270 & $\begin{array}{l}\text { EPA Administered Permit Programs: } \\
\text { The Hazardous Waste Permit System }\end{array}$ & $\begin{array}{l}\text { disposal facilities. } \\
\text { Establishes provisions for Hazardous Waste Permit Program under Subtitle } C \text { of } \\
\text { Solid Waste Disposal Act, as amended by RCRA. Regulations in this part cover } \\
\text { basic EPA permitting requirements such as application requirements, standards } \\
\text { permit conditions, and monitoring and reporting requirements. }\end{array}$ & 7 \\
\hline 40 CFR 300 & $\begin{array}{l}\text { Oil and Hazardous Substances } \\
\text { Pollution National Contingency Plan } \\
\text { (NCP) }\end{array}$ & $\begin{array}{l}\text { Eermit conditions, and montoring and } \mathrm{NCP} \text { guidelines to provide organizational structure and procedures for } \\
\text { preparing for and responding to discharges of oil and releases of hazardous } \\
\text { substances, pollutants, and contaminants. }\end{array}$ & 4 \\
\hline 40 CFR 302 & $\begin{array}{l}\text { Designation, Reportable Quantities, } \\
\text { and Notification }\end{array}$ & $\begin{array}{l}\text { substances, pollutants, and contaminants. } \\
\text { Identifies reportable quantities for substances designated under Comprehensive } \\
\text { Environmental Response, Compensation, and Liability Act (CERCLA) of 1980; } \\
\text { sets forth notification requirements for releases of these substances. }\end{array}$ & 19 \\
\hline 40 CFR 355 & $\begin{array}{l}\text { Emergency Planning and Notification } \\
\text { under CERCLA }\end{array}$ & $\begin{array}{l}\text { sets forth notification requirements tor teleases on } \\
\text { Establishes activity notification responsibilities. }\end{array}$ & 19 \\
\hline 40 CFR 370 & $\begin{array}{l}\text { Hazardous Chemical Reporting: } \\
\text { Community Right-to-Know Act }\end{array}$ & $\begin{array}{l}\text { Establishes reporting requirements to the public regarding hazardous chemicals in } \\
\text { their community. }\end{array}$ & 10 \\
\hline 40 CFR 372 & Toxic Chemical Release Reporting & $\begin{array}{l}\text { their community. } \\
\text { Establishes requirements for reporting toxic chemical releases. }\end{array}$ & 10 \\
\hline 40 CFR 373 & $\begin{array}{l}\text { Reporting Hazardous Substance } \\
\text { Activity when Selling or Transferring } \\
\text { Federal Real Property }\end{array}$ & $\begin{array}{l}\text { Establishes requirements for the requirements to report the storage, disposal, and release of hazardous } \\
\text { subsiances on U.S. property when being sold or transferred. }\end{array}$ & 10 \\
\hline
\end{tabular}


Table 2-1. Other Applicable Federal Requirements (Continued)

\begin{tabular}{|c|c|c|c|}
\hline $\begin{array}{c}\text { Statutel } \\
\text { Regulation }\end{array}$ & Tille & $\begin{array}{l}\text { Description } \\
\end{array}$ & $\begin{array}{l}\text { Applicable } \\
\text { SAR Chapter }\end{array}$ \\
\hline 40 CFR 761 & $\begin{array}{l}\text { Polychlorinated Biphenyls (PCBs)- } \\
\text { Manufacturing, Processing, } \\
\text { Distribution in Commerce, and use } \\
\text { Prohibitions }\end{array}$ & $\begin{array}{l}\text { Establishes prohibitions and requirements for manufacture, processing, } \\
\text { distribution in commerce, use, disposal, storage, and marking of PCBs and PCB } \\
\text { items. }\end{array}$ & 7 \\
\hline 49 CFR $100-181$ & $\begin{array}{l}\text { Department of Transportation (DOT) } \\
\text { Hazardous Material Transportation } \\
\text { Act regulations }\end{array}$ & Regulates packaging and transportation of hazardous materials. & 7 \\
\hline $\begin{array}{l}\text { CERCLA/SARA } \\
\text { Section } 120\end{array}$ & Federal Facilities & $\begin{array}{l}\text { Establishes coordination between Federal agencies to ensure the protection of } \\
\text { human health and the environment at Federal facilities under CERCLA/Superfund } \\
\text { Amendments and Reauthorization Act (SARA). }\end{array}$ & 20 \\
\hline
\end{tabular}


Table 2-2. Applicable DOE Orders

\begin{tabular}{|c|c|c|c|}
\hline Order & $\begin{array}{r}\text { Title } \\
\end{array}$ & $\begin{array}{l}\text { Description } \\
\end{array}$ & $\begin{array}{l}\text { Applicable } \\
\text { SAR Chapter }\end{array}$ \\
\hline DOE $1324.2 \mathrm{~A}$ & Records Disposition & $\begin{array}{l}\text { Assigns responsibilities and prescribes policies, procedures, standards, and } \\
\text { guidelines for orderly disposition of records of DOE and of operating contractors. }\end{array}$ & 18 \\
\hline DOE $1540.1 \mathrm{~A}$ & $\begin{array}{l}\text { Materials Transport and Traffic } \\
\text { Management }\end{array}$ & $\begin{array}{l}\text { Establishes DOE policies and procedures for management of material } \\
\text { transportation activities. }\end{array}$ & 7 \\
\hline DOE 1540.2 & $\begin{array}{l}\text { Hazardous Materials Packaging for } \\
\text { Transport-Administrative Procedures }\end{array}$ & $\begin{array}{l}\text { transportation activilies. } \\
\text { Establishes administrative procedures for certification and use of radioactive and } \\
\text { other hazardous materials packaging by DOE. }\end{array}$ & 10 \\
\hline DOE 4330.4A & Maintenance Management Program & $\begin{array}{l}\text { Provides general policy/ objectives for establishment of programs for } \\
\text { management and performance of cost-effective maintenance and repair of DOE } \\
\text { facilities. }\end{array}$ & 15 \\
\hline DOE 4700.1 & Project Management System & $\begin{array}{l}\text { facilities. } \\
\text { Establishes principles and requirements that govern development, approval, and } \\
\text { execution of DOE Project Management System. }\end{array}$ & 18 \\
\hline DOE 5000.3B & $\begin{array}{l}\text { Occurrence Reporting and Processing } \\
\text { of Operations Information }\end{array}$ & $\begin{array}{l}\text { Establishes reporting of unusual occurrences with programmatic significance for } \\
\text { DOE operation. }\end{array}$ & 19 \\
\hline DOE 5400.1 & $\begin{array}{l}\text { General Environmental Protection } \\
\text { Program }\end{array}$ & $\begin{array}{l}\text { DOE operation. } \\
\text { Establishes general DOE environmental program requirements. }\end{array}$ & 7 \\
\hline DOE 5400.3 & $\begin{array}{l}\text { Hazardous and Radioactive Mixed } \\
\text { Waste Program }\end{array}$ & $\begin{array}{l}\text { Establishes DOE hazardous and radioactive mixed waste policies and } \\
\text { implementation of RCRA requirements. }\end{array}$ & 7 \\
\hline DOE 5400.4 & CERCLA Requirements & $\begin{array}{l}\text { implementation of RCRA requirements. } \\
\text { Establishes DOE standards for compliance with CERCLA requirements with regard } \\
\text { to hazardous substances. }\end{array}$ & 20 \\
\hline DOE 5400.5 & $\begin{array}{l}\text { Radiation Protection of the Public and } \\
\text { the Environment }\end{array}$ & $\begin{array}{l}\text { to hazardous substances. } \\
\text { Establishes standards and requirements for DOE and contractor operations related } \\
\text { to protection of members of public and environment against undue risk from } \\
\text { radiation. }\end{array}$ & 9 \\
\hline DOE 5440.1E & $\begin{array}{l}\text { National Environmental Policy Act } \\
\text { Compliance Program }\end{array}$ & $\begin{array}{l}\text { radiation. } \\
\text { Establishes DOE standard for compliance with NEPA requirements }\end{array}$ & 7 \\
\hline DOE 5480.1B & $\begin{array}{l}\text { Environment, Safety, and Health } \\
\text { (ES\&H) Program for DOE Operations }\end{array}$ & Establishes ES\&H Program for DOE operations. & 6 \\
\hline DOE 5480.15 & $\begin{array}{l}\text { Department of Energy Laboratory } \\
\text { Accreditation Program for Personnel } \\
\text { Dosimetry }\end{array}$ & Establishes radiological dosimetry laboratory accreditation standards. & 9 \\
\hline DOE 5480.3 & $\begin{array}{l}\text { Safety Requirements for Packaging } \\
\text { and Transportation of Hazardous } \\
\text { Materials, Hazardous Substances, and } \\
\text { Hazardous Wastes }\end{array}$ & $\begin{array}{l}\text { Establishes tec anents for packaging and transporting of hazardous materials, } \\
\text { hazardous substances, and hazardous wastes. }\end{array}$ & 10,7 \\
\hline DOE 5480.4 & $\begin{array}{l}\text { Environmentai Protection, Safety, } \\
\text { and Heaith Protection Standards }\end{array}$ & $\begin{array}{l}\text { Specifies environmental protection, safety, and health standards broadly } \\
\text { applicable to DOE and contractors, with partial applicability } t w \text { environmental } \\
\text { remediation and decontamination and decommissioning (D\&D). }\end{array}$ & 6 \\
\hline DOE 5480.5 & Safety of Nuclear Facilities & $\begin{array}{l}\text { remediation and decontamination ano decom requirements. } \\
\text { Establishes nuclear facility safety program require }\end{array}$ & 17 \\
\hline DOE N5480.6 & Radiological Control Manual & $\begin{array}{l}\text { Establishes standard practices for control of radiological contamination and } \\
\text { personnel protection programs. }\end{array}$ & 9 \\
\hline
\end{tabular}


Table 2-2. Applicable DOE Orders (Continued)

\begin{tabular}{|c|c|c|c|}
\hline Order & Title & Description & $\begin{array}{l}\text { Applicable } \\
\text { SAR Chapter }\end{array}$ \\
\hline DOE 5480.7A & Fire Protection & $\begin{array}{l}\text { Establishes requirements for "improved risk" level of fire protection sufficient to } \\
\text { attain DOE objectives. }\end{array}$ & 17 \\
\hline DOE 5480.8A & $\begin{array}{l}\text { Contractor Occupational Medical } \\
\text { Program }\end{array}$ & $\begin{array}{l}\text { attain DOE objectives. } \\
\text { Establishes minimal Occupational Medical Program requirements for the DOE. }\end{array}$ & 10 \\
\hline DOE 5480.9 & Construction Safety and Health & Protection of workers, fublic, and property during construction. & 17 \\
\hline DOE 5480.10 & $\begin{array}{l}\text { Contractor Industrial Hygiene } \\
\text { Program }\end{array}$ & $\begin{array}{l}\text { Protection of workers, fublic, and } \\
\text { Establishes requirements and guidelines applicable to DOE contractor operations } \\
\text { for maintaining an effective industrial hygiene program. }\end{array}$ & 6,10 \\
\hline DOE 5480.11 & $\begin{array}{l}\text { Radiation Protection for Occupational } \\
\text { Workers }\end{array}$ & $\begin{array}{l}\text { for maintaining an elfective inoustishes radiation protection standards and program requirements for DOE and } \\
\text { contractor workers. }\end{array}$ & 9 \\
\hline DOE 5480.18A & $\begin{array}{l}\text { Accreditation of Performance-Based } \\
\text { Training for Category A Reactors and } \\
\text { Nuclear Facilities }\end{array}$ & $\begin{array}{l}\text { contractor workers. } \\
\text { Establishes performance-based training requirements for DOE reactor and non- } \\
\text { reactor nuclear facilities. }\end{array}$ & 13 \\
\hline DOE 5480.19 & Conduct of Operations & $\begin{array}{l}\text { Provides requirements and guidelines for developing directives, plans, and } \\
\text { procedures relating to conduct of operations at DOE facilities. }\end{array}$ & 17 \\
\hline DOE 5480.20 & $\begin{array}{l}\text { Personnel Selection, Qualification, } \\
\text { Training, and Staffing Requirements } \\
\text { at DOE Reactor and Non-Reactor } \\
\text { Nuclear Facilities }\end{array}$ & $\begin{array}{l}\text { Establishes selection, qualification, training, and staffing requirements for } \\
\text { personnel involved in operation, maintenance, and technical support of DOE- } \\
\text { owned, non-reactor nuclear facilities. }\end{array}$ & 13 \\
\hline DOE 5480.21 & Unreviewed Safety Questions (USQs) & Establishes definition and basis for determining existence of an USQ. & 12 \\
\hline DOE 5480.22 & Technical Safety Requirements (TSRs) & $\begin{array}{l}\text { Establishes requirements for preparation of TSRs for DOE nuclear facilities and } \\
\text { delineation of criteria, content, scope, format, approval process, revision, and } \\
\text { reporting requirements of TSR documents. }\end{array}$ & 16 \\
\hline DOE 5480.23 & Nuclear Safety Analysis Reports & $\begin{array}{l}\text { Establishes requirements for contractors responsible for design, construction, } \\
\text { operations, and D\&D of nuclear facilities to develop safety analyses that establish } \\
\text { and evaluate adequacy of safety bases of facilities. The nuclear Safety Analysis } \\
\text { Report (SAR) required by this Order documents results of safety analyses. }\end{array}$ & $1,5,6$ \\
\hline DOE 5480.28 & Natural Phenomena Hazard Mitigation & $\begin{array}{l}\text { Report (SAR) required by this } \\
\text { mitigation of natural phenomena }\end{array}$ & 5 \\
\hline DOE 5480.31 & $\begin{array}{l}\text { Startup and Restart of Nuclear } \\
\text { Facilities }\end{array}$ & $\begin{array}{l}\text { mitigation of natural phenomena } \\
\text { Establishes requirements for readiness reviews of nuclear facilities. }\end{array}$ & 16 \\
\hline DOE 5481.1B & Safety Analysis and Review System & $\begin{array}{l}\text { Provides uniform requirements for preparation and review of non-nuclear safety } \\
\text { analyses for DOE operations. }\end{array}$ & $1,5,6$ \\
\hline DOE 5482.1B & $\begin{array}{l}\text { Environment, Safety, and Health } \\
\text { Appraisal Program }\end{array}$ & $\begin{array}{l}\text { analyses for DOE operations. } \\
\text { Establishes ES\&H Appraisal Program for DOE. }\end{array}$ & 12 \\
\hline DOE 5483.1A & $\begin{array}{l}\text { Occupational Safety and Health } \\
\text { Program for DOE Contractor } \\
\text { Employees at Government-Owned } \\
\text { Contractor-Operated Facilities }\end{array}$ & $\begin{array}{l}\text { Establishes requirements and procedures to assure that occupational safety and } \\
\text { health standards (prescribed pursuant to Atomic Energy Act of 1954, as amended; } \\
\text { the Energy Reorganization Act of 1974; and DOE Organization Act of 1977) } \\
\text { provide occupational safety and health protection for DOE contractor employees } \\
\text { in Government-owned contractor-operated (GOCO) facilities. }\end{array}$ & 10 \\
\hline DOE 5484.1 & $\begin{array}{l}\text { Environmental Protection, Safety, } \\
\text { and Health Protection Information } \\
\text { Reporting Requirements }\end{array}$ & $\begin{array}{l}\text { in Government-owned contractor-operated } \\
\text { Establishes requirements and procedures for reporting information of ES\&H } \\
\text { significance for DOE operations. }\end{array}$ & 12 \\
\hline
\end{tabular}


Table 2-2. Applicable DOE Orders (Continued)

\begin{tabular}{|c|c|c|c|}
\hline Order & Title & $\begin{array}{c}\text { Description } \\
\end{array}$ & $\begin{array}{l}\text { Applicable } \\
\text { SAR Chapter }\end{array}$ \\
\hline DOE 5500.1B & Emergency Management System & $\begin{array}{l}\text { Establishes overall policy and requirements for DOE Emergency Management } \\
\text { System (EMS). EMS provides framework for development, coordination, and } \\
\text { direction of planning, preparedness, and readiness assurance activities. }\end{array}$ & 19 \\
\hline DOE 5500.2B & $\begin{array}{l}\text { Emergency Categories, Classes, and } \\
\text { Notification and Reporting } \\
\text { Requirements }\end{array}$ & $\begin{array}{l}\text { direction of planning, preparedishes DOE emergency categories, classes, and notification and reporting } \\
\text { requirements to facilitate communication and reporting of emergency events. }\end{array}$ & 19 \\
\hline DOE 5500.3A & $\begin{array}{l}\text { Planning and Preparedness for } \\
\text { Operational Emergencies }\end{array}$ & $\begin{array}{l}\text { Establishes requirements for planning and preparedness for operational } \\
\text { emergencies involving DOE or requiring DOE assistance. }\end{array}$ & 19 \\
\hline DOE 5500.4A & $\begin{array}{l}\text { Public Affairs Policy and Planning } \\
\text { Requirements for Emergencies }\end{array}$ & $\begin{array}{l}\text { Establishes requirements for DOE public affairs actions for emergency situations, } \\
\text { and provides guidelines to develop a public information plan to ensure necessary } \\
\text { public affairs actions are planned, coordinated, and taken as an integral part of } \\
\text { total emergency response effort. }\end{array}$ & 19 \\
\hline DOE 5500.10 & $\begin{array}{l}\text { Emergency Readiness Assurance } \\
\text { Program }\end{array}$ & $\begin{array}{l}\text { total emergency response effort. } \\
\text { Establishes the requirements for assuring the continued readiness of the Emergency } \\
\text { Management System for response to an emergency. }\end{array}$ & 19 \\
\hline DOE 5631.1B & Security Education Program & Establishes physical protection training requirements. & 13 \\
\hline DOE 5700.6C & Quality Assurance & Establishes physical protishes quality assurance requirements for DOE. & 18 \\
\hline DOE 5820.2A & Radioactive Waste Management & Establishes requirements for DOE management of radioactive and mixed waste. & 7 \\
\hline DOE 6430.1A & General Design Criteria Manual & $\begin{array}{l}\text { Provides general design criteria and establishes responsibilities and authorities for } \\
\text { development and maintenance of criteria. }\end{array}$ & 21 \\
\hline
\end{tabular}


Table 2-3. Requirements for Process Safety Management

\begin{tabular}{|c|c|c|c|}
\hline Reference & Title & Description & $\begin{array}{l}\text { Applicable SAR } \\
\text { Chapters }\end{array}$ \\
\hline 29 CFR $1910.119(a)$ & Application & $\begin{array}{l}\text { Explains the types and quantities of materials and processes where a program is } \\
\text { required. }\end{array}$ & $4,5,10$ \\
\hline 29 CFR 1910.119(b) & Definitions & $\begin{array}{l}\text { required. } \\
\text { Defines terms in the regulation. }\end{array}$ & \\
\hline 29 CFR $1910.119(\mathrm{c})$ & Employee Participation & $\begin{array}{l}\text { Defines terms in the regulation. } \\
\text { Requires employee participation during planning and access to process safety } \\
\text { management information. }\end{array}$ & 12 \\
\hline 29 CFR $1910.119(d)$ & Process Safety Information & $\begin{array}{l}\text { management information. } \\
\text { Requires compilation of significant properties of hazardous materials in process, the } \\
\text { design parameters of the process and the equipment therein. }\end{array}$ & $4,5,10$ \\
\hline 29 CFR $1910.119(\mathrm{e})$ & Process Hazard Analysis & $\begin{array}{l}\text { Requires analysis of process hazards using approved methods, identification of } \\
\text { incidents involving the process, hazard controls, consequences of failures, siting, } \\
\text { and human factors. }\end{array}$ & $3,5,10,11,14$ \\
\hline 29 CFR 1910.119(f) & Operating Procedures & $\begin{array}{l}\text { and human factors. } \\
\text { Requires operating procedures with instructions for safely operating the process. }\end{array}$ & 13 \\
\hline 29 CFR $1910.119(\mathrm{~g})$ & Training & Requires operating procedures whes initial training, refresher training, and training documentation. & 13 \\
\hline 29 CFR $1910.119(\mathrm{~h})$ & Contractors & $\begin{array}{l}\text { Requires initial training, refresher traning, and } \\
\text { Describes obligations of the employer and contrsctor for compliance with process } \\
\text { safety management requirements. }\end{array}$ & 12,13 \\
\hline 29 CFR 1910.119(i) & Pre-Startup Safety Review & $\begin{array}{l}\text { safety management requirements. } \\
\text { Requires confirmation that design is in accordance with specification, review of } \\
\text { adequacy of procedures, confirmation that hazards analysis recommendations are } \\
\text { implemented, and verification of training. }\end{array}$ & 17,18 \\
\hline 29 CFR 1910.119(i) & Mechanical Integrity & $\begin{array}{l}\text { implemented, and veritication of training. } \\
\text { Requires provision for maintaining the integrity of the process system. }\end{array}$ & $15,17,18$ \\
\hline 29 CFR 1910.119(k) & Hot Work Permit & Requires provision tor maintaining & 10,17 \\
\hline 29 CFR $1910.119(1)$ & Management of Change & $\begin{array}{l}\text { Requires documented control or neal sources. } \\
\text { Requires documented procedure for safety review of changes other thatreaplacements- } \\
\text { in-kind }\end{array}$ & $12,17,18$ \\
\hline 29 CFR $1910.119(\mathrm{~m})$ & Incident Investigation & $\begin{array}{l}\text { in-kind } \\
\text { Requires incident investigation of any incident which resulted in, or could have } \\
\text { resulted in, a catastrophic release of hazardous material }\end{array}$ & 12.17 \\
\hline 29 CFR 1910.119(n) & $\begin{array}{l}\text { Emergency Planning and } \\
\text { Response }\end{array}$ & $\begin{array}{l}\text { resulted in, a catasurophic release of hazaroous mate } \\
\text { Requires emergency action plan in accordance with } 29 \text { CFR 1910.38, including } \\
\text { plans for small releases. }\end{array}$ & 19 \\
\hline 29 CFR 1910.119(o) & Compliance Audits & $\begin{array}{l}\text { plans for small releases. } \\
\text { Requires triennial audits of compliance with process safety management standards. }\end{array}$ & 12,18 \\
\hline 29 CFR $1910.119(p)$ & Trade Secrets & $\begin{array}{l}\text { Requires triennial audits of compuance } \\
\text { Requires access be given to program information to those with need-to-know; } \\
\text { nondisclosure agreements may be required. }\end{array}$ & 12 \\
\hline
\end{tabular}




\subsection{SITE CHARACTERISTICS}

This section provides information on natural phenomena and surrounding activities which may affect the safe operation of a vitrification facility or irtegrated mixed waste treatment facility employing vitrification processes. Section 3.1 provides a summary of the setting of major DOE complex sites; Section 3.2 describes the seismic characteristics of candidate sites; Section 3.3 discusses wind hazards at candidate sites; Section 3.4 addresses surface water flooding potential for the sites; and Section 3.5 describes transportation system needs and required utilities.

Future decision-makers may deem many of the DOE Complex sites as clearly incompatible with, or irrelevant to, the deployment of mixed waste treatment technology. Such a determination probably will be made during site assessments incorporating both safety analyses and economic analyses. A conclusive site selection assessment is beyond the scope of this PHA.

\subsection{SITE LOCATIONS}

This section summarizes the settings and locations of candidate DOE sites for a facility'. Property site areas provide a general measure of potential isolation from offsite populations should an accident occur. A general ranking of potential isolation based on site areas is given in Table 3-1. This ranking is based on a maximum potential source-to-receptor distance for the particular area specified, i.e., the radius of a circle whose area is equivalent to the site area. The actual distance to potential offsite receptors can only be determined during evaluation of the specific site.

\subsubsection{Kansas City Plant}

The Kansas City Plant is part of the Bannister Federal Complex, located 12 miles south of downtown Kansas City, Missouri. Manufacturing operations are housed in 3.2 million square feet of building space (DOE 1991c).

\subsubsection{Los Alamos National Laboratory}

Los Alamos National Laboratory (LANL) occupies about 43 square miles in Los Alamos County, 60 miles north of Albuquerque, New Mexico, and 25 miles northwest of Santa Fe, New Mexico. The laboratory is situated on the Parajito Plateau, a finger-like mesa ranging in elevation from $6,200 \mathrm{ft}$ to $7,800 \mathrm{ft}$ (DOE 1991c). 


\subsubsection{Mound Laboratory}

Mound Laboratory is located within the southem city limits of Miamisburg in southwestem Ohio. The plant site occupies 306 acres of land overlooking Miamisburg and the Great Miami River. The Dayton, Ohio metropolitan area is located 10 miles northeast of the installation (DOE 1991c).

Table 3-1. Maximum Potential Source-Receptor Isolation for DOE Sites

\begin{tabular}{|l|c|c|}
\hline \multicolumn{1}{|c|}{ DOE Site } & $\begin{array}{c}\text { Site Area } \\
\left(\mathbf{m}^{2}\right)\end{array}$ & $\begin{array}{c}\text { Maximum Source-Receptor } \\
\text { Distance (m) }\end{array}$ \\
\hline Nevada Test Site & $3.50 \mathrm{E}+09$ & $3.3 \mathrm{E}+04$ \\
\hline Argonne National Laboratory, West & $2.31 \mathrm{E}+09$ & $2.7 \mathrm{E}+04$ \\
\hline Idaho National Engineering Laboratory & $2.31 \mathrm{E}+09$ & $2.7 \mathrm{E}+04$ \\
\hline Hanford Site & $1.45 \mathrm{E}+09$ & $2.1 \mathrm{E}+04$ \\
\hline Savannah River Plant & $8.42 \mathrm{E}+08$ & $1.6 \mathrm{E}+04$ \\
\hline Los Alamos National Laboratory & $1.11 \mathrm{E}+08$ & $5.9 \mathrm{E}+03$ \\
\hline Pantex Plant & $6.48 \mathrm{E}+07$ & $4.5 \mathrm{E}+03$ \\
\hline Rocky Flats Plant & $2.89 \mathrm{E}+07$ & $3.0 \mathrm{E}+03$ \\
\hline LLNL Site 300 & $2.85 \mathrm{E}+07$ & $3.0 \mathrm{E}+03$ \\
\hline Brookhaven National Laboratory & $2.15 \mathrm{E}+07$ & $2.6 \mathrm{E}+03$ \\
\hline Portsmouth Gaseous Diffusion Plant & $1.50 \mathrm{E}+07$ & $2.2 \mathrm{E}+03$ \\
\hline Paducah Gaseous Diffusion Plant & $1.39 \mathrm{E}+07$ & $2.1 \mathrm{E}+03$ \\
\hline Oak Ridge National Laboratory & $1.17 \mathrm{E}+07$ & $1.9 \mathrm{E}+03$ \\
\hline Sandia National Laboratories, Albuquerque & $1.14 \mathrm{E}+07$ & $1.9 \mathrm{E}+03$ \\
\hline Energy Technology and Engineering Center & $1.09 \mathrm{E}+07$ & $1.9 \mathrm{E}+03$ \\
\hline Argonne National Laboratory, East & $6.88 \mathrm{E}+06$ & $1.5 \mathrm{E}+03$ \\
\hline Oak Ridge National Laboratory, K-25 Site & $6.07 \mathrm{E}+06$ & $1.4 \mathrm{E}+03$ \\
\hline Feed Materials Production Center, Femald & $4.25 \mathrm{E}+06$ & $1.2 \mathrm{E}+03$ \\
\hline Oak Ridge National Laboratory, Y-12 Site & $3.28 \mathrm{E}+06$ & $1.0 \mathrm{E}+03$ \\
\hline Lawrence Livermore National Laboratory & $2.59 \mathrm{E}+06$ & $9.0 \mathrm{E}+02$ \\
\hline Stanford Linear Accelerator Center & $1.72 \mathrm{E}+06$ & $7.4 \mathrm{E}+02$ \\
\hline Sandia National Laboratories, Califormia & $1.67 \mathrm{E}+06$ & $7.3 \mathrm{E}+02$ \\
\hline Mound Laboratory & $1.24 \mathrm{E}+06$ & $6.3 \mathrm{E}+02$ \\
\hline Lawrence Berkeley Laboratory & $5.26 \mathrm{E}+05$ & $4.1 \mathrm{E}+02$ \\
\hline Pinellas Plant, Florida & $4.02 \mathrm{E}+05$ & $3.6 \mathrm{E}+02$ \\
\hline Kansas City Plant & $2.97 \mathrm{E}+05$ & $3.1 \mathrm{E}+02$ \\
\hline
\end{tabular}

\subsubsection{Pantex Plant}

Pantex is located in the panhandle of Texas, 17 miles northeast of downtown Amarillo, Texas, and ten rniles west of the town of Panhandle. Pantex includes a total land area of about 16,000 acres. The total population within a 50-mile radius of the plant was 259,300 in 1980 (DOE 1991c). 


\subsubsection{Rocky Flats Plant}

Rocky Flats Plant is located in northem Jefferson County, 16 miles northwest of Denver. Colorado. The plant site covers 11 square miles (DOE 1991c).

\subsubsection{Sandia National Laboratories, New Mexico}

Sandia National Laboratories, New Mexico (SNL/N) occupies several parcels of land covering 2,820 acres within Kirtland Air Force Base, directly south of Albuquerque, New Mexico (DOE 1991c).

\subsubsection{Sandia National Laboratories, California}

Sandia National Laboratories, Califomia, (SNL/CA) lies 40 miles east of San Francisco in the Livermore Valley, three miles east of the Livermore city center. SNL/CA occupies 413 acres of land, only a few city blocks from the edge of the city of Livermore. In 1988, the population within 50 miles was estimated at nearly 6,000,000 (DOE 1991c).

\subsubsection{Pinellas Plant}

The Pinellas Plant is located on a 99.2 acre site, 6 miles north of St. Petersburg in Pine!las County, Florida. Pinellas County is on a peninsula bordered on the west by the Gulf of Mexico and on the east and south by Tampa Bay. The 1989 census estimated a population of 870,162 in Pinellas County (DOE 1991c).

\subsubsection{Argonne National Laboratory, East}

Argonne National Laboratory - East (ANL-E) occupies a 1,700 acre tract located 22 miles southwest of downtown Chicago in Dupage County, Illinois (DOE 1991c).

\subsubsection{Argonne National Laboratory, West}

Argonne National Laboratory - West (ANL-W) is located on the southeastem portion of the Idaho National Engineering Laboratory (INEL) near Idaho Falls, Idaho (see 3.1.12 below) (DOE 1991c).

\subsubsection{Brookhaven National Laboratory}

Brookhaven National Laboratory (BNL) is located in central Suffolk County, New York. on Long Island, 60 miles east of New York City. The site consists of an 8.3 square mile tract, most of which is wooded, save for a 2.3 square mile developed area. The laboratory is located over an EPA-designated, sole source drinking water aquifer (DOE 1991c). 


\subsubsection{Idaho National Engineering Laboratory}

Idaho National Engineering Laboratory (INEL), situated in southem Idaho along the westem edge of the Eastem Snake River Plains, encompasses an area of approximately 890 square miles of desert. The nearest major community is Idaho Falls, population 46,000 , located 42 miles southeast of INEL (DOE 1991C).

\subsubsection{Feed Materials Production Center, Fernald}

The Feed Materials Production Center is located near Fernald, Ohio, northwest of Cincinnati. The site occupies 1,050 acres (DOE 1991c).

\subsubsection{Oak Ridge National Laboratory, including X-10, K-25 and Y-12 Sites}

Oak Ridge National Laboratory (ORNL) occupies several sites and covers approximately 2,900 acres in Melton Valley and Bethel Valley, 10 miles southwest of downtown Oak Ridge, Tennessee (DOE 1991c).

The Oak Ridge K-25 site occupies a 1,500 acre area adjacent to the Clinch River, approximately 13 miles west of downtown Oak Ridge, Tennessee (DOE 199/c).

The Oak Ridge Y-12 site occupies a 811 acre site in Bear Creek Valley, 2 miles from downtown Oak Ridge, Tennessee (DOE 1991c).

\subsubsection{Paducah Gaseous Diffusion Plant}

The Paducah Gaseous Diffusion Plant is located 15 miles west of Paducah, Kentucky. The site occupies 750 acres, with 74 acres of process buildings, within a 3,422 acre tract of DOEowned property (DOE 1991c).

\subsubsection{Portsmouth Gaseous Diffusion Plant}

The Portsmouth Gaseous Diffusion Plant is located 20 miles north of Portsmouth, Ohio. The site covers 3,700 acres, including 93 acres of process buildings (DOE 1991c).

\subsubsection{Nevada Test Site}

The Nevada Test Site (NTS) occupies approximately 1,350 square miles of desert in southwestem Nevada. Thi closest major population center is Las Vegas, 65 miles southeast of NTS (DOE 1991C). 


\subsubsection{Hanford Project Site}

The Hanford Site encompasses 560 square miles within the Columbia River Basin in southeastem Washington State. This high desert area is located immediately to the north of Richland, Kennewick, and Pasco, Washington (combined population 100,000) (DOE 199 Ic).

\subsubsection{Lawrence Berkeley Laboratory}

Lawrence Berkeley Laboratory (LBL) consists of 130 acres located near urban Berkeley. Califomia, on land leased to DOE by the University of California. The site is bordered on the north by predominantly single-family residences and on the west by multi-family residences. student residence halls, and commercial districts (DOE 199lc).

\subsubsection{Lawrence Livermore National Laboratory Including Site 300}

Lawrence Livermore National Laboratory (LLNL) Main Site covers one square mile and is located approximately four miles from the Livermore, Califomia, city center. Medium and highdensity housing within the City of Livermore, population 50,000, borders the west side of the site. Low-density industrial and agriculture! areas adjoin the north, east, and south borders of the site (DOE 1991c).

LLNL Site 300 - Area 854 is located within the overall Site 300 tract. 15 miles east of the LLNL Main Site. Site 300 covers 11 square miles and is surrounded by low-density agricultural land in the Diablo Range of Califomia (DOE 1991c).

\subsubsection{Energy Technology and Engineering Center, Santa Susanna}

The Energy and Technology Engineering Center (ETEC) is located within the Santa Susanna Field Laboratory, 30 miles northwest of downtown Los Angeles, Califomia. The ETEC consists of government buildings on a 90 acre site within the overall 2,700 acre Santa Susanna Field Laboratory property (DOE 1991c).

\subsubsection{Stanford Linear Accelerator Center}

The Stanford Linear Accelerator Center (SLAC) site covers 426 acres of low rolling foothills in unincorporated San Mateo County, Califomia. SLAC is located 25 miles south of San Francisco and 15 miles northwest of San Jose. The eastem border is adjacent to the Stanford University campus. Medium-density shopping, residential, and professional buildings are located north of SLAC. Low-density single family residences are located to the south of SLAC (DOE 1988a). 


\subsubsection{Savannah River Plant}

The Savannah River Plant is located in south central South Carolina. and is bordered on the southwestem side by the Savannah River. The closest major population centers are Aiken, South Carolina and Augusta. Georgia. The total area of the site is approximately 325 square miles with production facilities occupying less than 5 percent of the site area (LUE 1991c).

\subsection{SEISMICITY}

The safety analysis hazard categorization of a facility determines its designated usage category under UCRL-15910, Design and Evaluation Guidelines for Department of Energy Facilities Subjected to Natural Phenomena Hazards (Kennedy et al. 1990). Each usage category is assigned an annual probability of exceedance for seismic events, as defined by the UCRL, which is used in the analysis of facility response to seismic events. For major DOE sites, UCRL-15910 presents seismic horizontal ground accelerations corresponding to these annual probabilities of exceedance.

Table 3.2 ranks the major DOE sites by respective ground acceleration values for the three standard annual probability of exceedance rates. A facility installed at a site appearing at the top of the table would require less sophisticated seismic hazard evaluation and could be more easily designed to survive credible seismic events.

\subsection{EXTREME WINDS}

Extreme winds, including cyclonic storms and tomadoes, are assessed by UCRL-15910 (Kennedy et al. 1990), with annual probabilities of exceedance assigned for specific wind loads at each DOE site. These wind load criteria and the requirements for DOE Order 6430.1A assure that facilities of a given usage category are designed to withstand credible structural wind loads as well as windborne missiles.

Table 3-3 presents a ranking of major DOE sites by respective fastest-mile wind speeds for each usage category. Sites appearing at the top of the table would require less sophisticated design evaluation for wind hazards and could be more easily designed to withstand credible structural wind loads and missiles. 
Table 3-2. Horizontal Ground Motion Criteria and Annual Probability of Exceedance at DOE Sites

\begin{tabular}{|l|c|c|c|}
\hline \multirow{2}{*}{ DOE Site } & \multicolumn{2}{c|}{ Annual Probability of Exceedance } \\
\cline { 2 - 4 } & & & \\
& $2.00 \mathrm{E}-03$ & $1.00 \mathrm{E}-03$ & $\mathbf{2 . 0 0 E}-04$ \\
\hline \multirow{2}{*}{ Pinellas Plant. Florida } & & & \\
\hline Pantex Plant & $0.04 \mathrm{~g}$ & $0.05 \mathrm{~g}$ & $0.09 \mathrm{~g}$ \\
\hline Kansas City Plant & 0.08 & 0.10 & 0.17 \\
\hline Portsmouth Gaseous Diffusion Plant & 0.08 & 0.10 & 0.17 \\
\hline Savannah River Plant & 0.08 & 0.11 & 0.17 \\
\hline Hanford Site & 0.08 & 0.11 & 0.19 \\
\hline Argonne National Laboratory, East & 0.09 & 0.12 & 0.17 \\
\hline Feed Materials Production Center. Fermald & 0.09 & 0.12 & 0.21 \\
\hline Argonne National Laboratory, West & 0.10 & 0.13 & 0.20 \\
\hline Idaho National Engineering Laboratory & 0.12 & 0.14 & 0.21 \\
\hline Mound Laboratory & 0.12 & 0.14 & 0.21 \\
\hline Brookhaven National Laboratory & 0.12 & 0.15 & 0.23 \\
\hline Rocky Flats Plant & 0.12 & 0.15 & 0.25 \\
\hline Oak Ridge National Laboratory & 0.13 & 0.15 & 0.21 \\
\hline Sandia National Laboratories, Albuquerque & 0.15 & 0.19 & 0.32 \\
\hline Los Alamos National Laboratory & 0.17 & 0.22 & 0.38 \\
\hline Nevada Test Site & 0.18 & 0.22 & 0.38 \\
\hline LLNL Site 300 - Areas 834 and 836 & 0.21 & 0.27 & 0.48 \\
\hline LLNL Site 300 - Area 854 & 0.28 & 0.34 & 0.51 \\
\hline Lawrence Livermore National Laboratory & 0.32 & 0.38 & 0.56 \\
\hline Sandia National Laboratories, California & 0.41 & 0.48 & 0.68 \\
\hline Paducah Gaseous Diffusion Plant & 0.41 & 0.48 & 0.68 \\
\hline Stanford Linear Accelerator Center & 0.33 & 0.45 & $*$ \\
\hline Energy Technology and Engineering Center & 0.45 & 0.59 & $*$ \\
\hline Lawrence Berkeley Laboratory & 0.53 & 0.59 & $*$ \\
\hline
\end{tabular}

*Value not given in Kennedy et al., 1990 and must be specifically determined for high hazard facilities.

\subsection{FLOODING}

Flcod hazard curves corresponding to the annual probabilities of exceedance in UCRL15910 (Kennedy et al. 1990) have been estimated for selected DOE facilities during the DOE Natural Phenomena Hazard Project (Savy and Murray 1988). Facility structures, including site drainage, foundation design, and roof design, must meet bounding design criteria for protection against extreme precipitation and surface water intrusion during a Design Basis Flood corresponding to the usage category annual probability of exceedance. 
Table 3-3. Recommended Design Wind and Tornado Speed Criteria and Annual Probability of Exceedance at DOE Sites

\begin{tabular}{|c|c|c|c|c|}
\hline & $\begin{array}{l}\text { Low Hazard } \\
\text { Wind Load } \\
\text { (mph) }\end{array}$ & $\begin{array}{c}\text { Moderate } \\
\text { Hazard } \\
\text { Wind Load } \\
\text { (mph) } \\
\end{array}$ & $\begin{array}{c}\text { High Hazard } \\
\text { Wind Load } \\
(\mathrm{mph})\end{array}$ & $\begin{array}{c}\text { Moderate/High } \\
\text { Hazard } \\
\text { Tornado Load } \\
\text { (mph) } \\
\end{array}$ \\
\hline DOE Site & $2.00 E-02 / y$ & $1.00 \mathrm{E} \cdot 03 / \mathrm{y}$ & $1.00 \mathrm{E}-04 / \mathrm{y}$ & $2.00 \mathrm{E}-05 / \mathrm{y}$ \\
\hline Hanford Site & 70 & 80 & 90 & - \\
\hline Argonne National Laboratory, West & 70 & 83 & 95 & - \\
\hline Brookhaven National Laboratory & 70 & - & $=$ & 95 \\
\hline $\begin{array}{l}\text { Energy Technology and Engineering } \\
\text { Center }\end{array}$ & 70 & - & - & 95 \\
\hline $\begin{array}{l}\text { Idaho National Engineering } \\
\text { Laboratory }\end{array}$ & 70 & 84 & 95 & - \\
\hline Nevada Test Site & 72 & 87 & 100 & - \\
\hline Kansas City Plant & 72 & 93 & 107 & $=$ \\
\hline Los Alamos National Laboratory & 77 & 93 & 107 & - \\
\hline $\begin{array}{l}\text { Portsmouth Gaseous Diffusion } \\
\text { Plant }\end{array}$ & 70 & - & - & 110 \\
\hline Lawrence Berkeley Laboratory & 72 & 95 & 112 & - \\
\hline Stanford Linear Accelerator Center & 72 & 95 & 112 & - \\
\hline Oak Ridge National Laboratory & 70 & - & - & 113 \\
\hline $\begin{array}{l}\text { Lawrence Livermore National } \\
\text { Laboratory }\end{array}$ & 72 & 96 & 113 & - \\
\hline $\begin{array}{l}\text { Sandia National Laboratories, } \\
\text { Califomia }\end{array}$ & 72 & 96 & 113 & - \\
\hline $\begin{array}{l}\text { Lawrence Livermore National } \\
\text { Laboratory, Site } 300\end{array}$ & 80 & 104 & 125 & - \\
\hline Pantex Plant & 78 & - & $=$ & 132 \\
\hline $\begin{array}{l}\text { Sandia National Laboratories, } \\
\text { Albuquerque }\end{array}$ & 78 & - & - & 132 \\
\hline Mound Laboratory & 73 & - & - & 136 \\
\hline Savannah River Plant & 78 & - & $=$ & 137 \\
\hline $\begin{array}{l}\text { Feed Materials Production Center, } \\
\text { Femald }\end{array}$ & 70 & - & - & 139 \\
\hline Argonne National Laboratory, East & 70 & $=$ & $=$ & 142 \\
\hline Paducah Gaseous Diffusion Plant & 70 & - & - & 144 \\
\hline Pinellas Plant, Florida & 93 & 130 & 150 & $=$ \\
\hline Rocky Flats Plant & 109 & 138 & 161 & - \\
\hline
\end{tabular}

Table 3-4 presents a ranking of flood hazard curve characteristics for those selected major DOE sites where data are available (Savy and Murray 1988). Flood hazard curves present graphical data on the maximum flood water level for a site versus retum period in years. From this, annual probability values can be derived. Sites appearing at the top of the table would require less sophisticated design evaluation for precipitation and flooding hazards and could be more easily designed to withstand credible floods and local precipitation. 
Table 3-4. Mean Flood Hazard Elevation Criteria and Annual Probabilities of Exceedance for DOE Sites

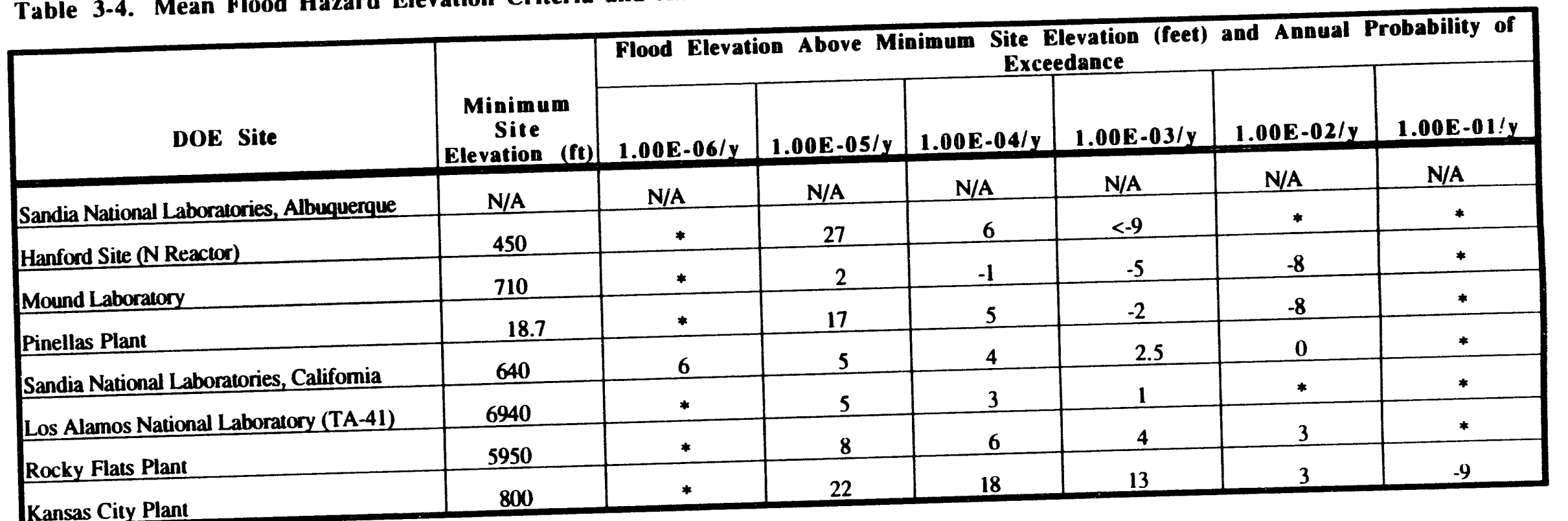

Kansas City Plant

*Flood level unavailable from flood hazard curves.

N/A indicates flood was not credible. 


\subsection{TRANSPORTATION AND UTILITIES}

Each of the major DOE sites discussed in this section contain sufficient industrial infrastructure to support a vitrification or integrated mixed waste treatment facility. An important consideration in site selection may be the availability of transport routes appropriate to the movement of construction materials, system components, mixed waste, and consumables such as diesel fuel. Transportation rutes to and from the site must accommodate the weight and sizes of system components. Sufficient water supplies must be provided for process water, fire protection. and drinking water. The site must have suitable provisions for stormwater and sewage. Fire protection, sewer, and stormwater systems for the facility must be designed consistent with DOE design criteria for non-reactor nuclear facilities (DOE 1989a).

System electrical demands are likely to be high during vitrification melter operation. High voltage electrical distribution will be necessary to supply system operational needs. Diesel generators may be employed to supply backup power. Transportation systems and site civil engineering should account for fuel transportation and tank storage needs if diesel generation is used.

\subsection{DOE ORDER 5480.28}

For several years has UCRL-15910 (Kennedy et al. 1990) been used to establish performance goals for new DOE facilities in accordance with the requirements of DOE Order 6430.1A (DOE 1989a). This DOE Design Criteria order is being updated and DOE 6430.1B has been published in draft. These updated criteria are complementary to the new requirements recently issued for nuclear facilities in DOE Orders 5480.23 (DOE 1992a) and 5480.28 (DOE 1993b). The latter introduces new requirements for natural phenomena hazard mitigation for DOE facilities and has several associated guidance documents (DOE 1992d; 1992e; 1993c; 1993d; 1993f) some of which have been issued in final form and some of which are still in draft. These guidance documents revise and update the methods in UCRL-15910. The guidance documents institute a new and expanded performance categorization system over that in the UCRL and necessitate their implementation and use DOE-wide. The new DOE Order 5480.28 categorization and performance criteria are summarized in Table 3-5.

As the revised DOE Design Criteria Order has not yet been finalized, both systems have been addressed in this PHA. It should be noted that there is no serious conflict between the two systems (i.e., that of UCRL-15910 and that of the 5480.28 guidance documents) as they are based on the same methods and probability curves. These curves were published by Coats and Murray (1984; 1985) and Savy and Murray (1988) and form the basis of both systems. 
Table 3-5. DOE 5480.28 Performance Criteria

\begin{tabular}{|c|c|c|c|c|c|c|c|c|c|c|c|c|c|}
\hline \multirow[b]{2}{*}{ DOE Site } & \multicolumn{3}{|c|}{$\begin{array}{l}\text { Estimated Horizontal Seismic } \\
\text { Load (g) by DOE 5480.28 } \\
\text { Performance Category (PC) } \\
\end{array}$} & \multicolumn{6}{|c|}{$\begin{array}{l}\text { Wind and Tormado Speeds (MPH) by DOE } 5480.28 \text { Performance } \\
\text { Category }\end{array}$} & \multicolumn{4}{|c|}{ Flood (ft above facillity grade) } \\
\hline & $\begin{array}{c}\text { PC 1 } \\
(1 E-3 / y)\end{array}$ & $\begin{array}{c}\text { PC 2 } \\
(5 E-4 / y)\end{array}$ & $\begin{array}{c}\text { PC 3 } \\
(1 E-4 / y)\end{array}$ & $\begin{array}{c}\text { PC } 1 \\
\text { Wind } \\
(2 E-2 / y)\end{array}$ & $\begin{array}{c}\text { PC 2 } \\
\text { Wind } \\
(2 E-2 / y)\end{array}$ & $\begin{array}{c}\text { PC } 3 \\
\text { Wind } \\
(1 E \cdot 3 / y)\end{array}$ & $\begin{array}{c}\text { PC } 3 \\
\text { Toraado } \\
(2 E-5 / y) \\
\end{array}$ & $\begin{array}{c}\text { PC } 4 \\
\text { Wind } \\
(1 E-4 / y)\end{array}$ & $\begin{array}{c}\text { PC 4 } \\
\text { Toraado } \\
(2 E-6 / y) \\
\end{array}$ & $\begin{array}{c}\text { PC 1 } \\
(1 E-3 / y)\end{array}$ & $\begin{array}{r}P C: 2 \\
(5 E-4 / y) \\
\end{array}$ & $\begin{array}{c}P C 3 \\
(1 E-4 / y)\end{array}$ & $\begin{array}{c}P C+ \\
(5 E-5 / y)\end{array}$ \\
\hline Argonne NL,E & 0.12 & 0.16 & 0.26 & 70 & 70 & - & $1+2$ & - & 196 & - & - & - & - \\
\hline Argonne NL,W & 0.14 & 0.17 & 0.24 & 70 & 70 & 83 & - & 95 & - & $=$ & $=$ & $=$ & - \\
\hline Brookhaven NL & 0.15 & 0.18 & 0.30 & 70 & 70 & - & 95 & - & 145 & - & - & - & $=$ \\
\hline $\begin{array}{l}\text { Energy } \\
\text { Technology and } \\
\text { Engineering } \\
\text { Center }\end{array}$ & 0.59 & 0.69 & - & 70 & 70 & - & 95 & 111 & & - & - & - & - \\
\hline $\begin{array}{l}\text { Feed Materials } \\
\text { Production } \\
\text { Center, Femald } \\
\text { CH } \\
\end{array}$ & 0.13 & 0.15 & 0.24 & 70 & 70 & - & 139 & - & 192 & - & - & - & - \\
\hline Henford Sile & 0.12 & 0.14 & 0.20 & 70 & 70 & 80 & - & 90 & - & $\begin{array}{l}<-9 \\
\text { (N-Reactor) }\end{array}$ & $\begin{array}{l}-1 \\
\text { (N-Reactor) }\end{array}$ & $\begin{array}{l}6 \\
\text { (N-Reactor) }\end{array}$ & $\begin{array}{l}27 \\
\text { (N-Reactor) }\end{array}$ \\
\hline Idhho NEL & 0.14 & 0.17 & 0.24 & 70 & 70 & 84 & - & 95 & - & & & & \\
\hline $\begin{array}{l}\text { Kansas City } \\
\text { Plant }\end{array}$ & 0.1 & 0.13 & 0.21 & 72 & 72 & - & 144 & - & 198 & 12 & 15 & 18 & 19 \\
\hline $\begin{array}{l}\text { Lawrence } \\
\text { Berkeley } \\
\text { Laboralory }\end{array}$ & 0.64 & 0.85 & - & 72 & 72 & 95 & - & 111 & - & - & - & 一 & 一 \\
\hline $\begin{array}{l}\text { Lawrence } \\
\text { Livernore NL }\end{array}$ & 0.48 & 0.56 & 0.9 & 72 & 72 & 96 & - & 113 & - & - & - & - & - \\
\hline $\begin{array}{l}\text { Lawrence } \\
\text { Livermore NL. } \\
\text { Site } 300\end{array}$ & 0.36 & 0.43 & 0.63 & 80 & 80 & 104 & - & 125 & - & - & - & - & - \\
\hline Los Alamos NL & 0.22 & 0.28 & 0.47 & 77 & 77 & 93 & - & 107 & - & $\begin{array}{l}1 \\
(T A-41)\end{array}$ & 2 & $\begin{array}{l}3 \\
(\mathrm{TA}+1)\end{array}$ & $\begin{array}{l}5 \\
(\mathrm{TA}-41) \\
\end{array}$ \\
\hline $\begin{array}{l}\text { Mound } \\
\text { Laboratory }\end{array}$ & 0.15 & 0.18 & 0.31 & 73 & 73 & - & 136 & - & 188 & -5 & -3 & -1 & 0 \\
\hline Nevada Test Site & 0.27 & 0.34 & 0.56 & 72 & 72 & 87 & $=$ & 100 & - & $=$ & - & - & $=$ \\
\hline Oak Ridge NL & 0.19 & 0.24 & - & 70 & 70 & - & 113 & $=$ & 173 & $=$ & - & - & $=$ \\
\hline $\begin{array}{l}\text { Oak Ridge } \\
\text { NL,K-25 }\end{array}$ & 0.19 & 0.24 & - & 70 & 70 & - & 113 & - & 173 & - & - & - & - \\
\hline $\begin{array}{l}\text { Oak Ridge } \\
\text { NL, Y-12 }\end{array}$ & 0.19 & 0.24 & - & 70 & 70 & - & 113 & - & 173 & - & 一 & - & - \\
\hline $\begin{array}{l}\text { Paducah Gaseous } \\
\text { Diffusion Plant }\end{array}$ & 0.45 & 0.61 & - & 70 & 70 & - & 144 & - & 198 & - & - & - & 一 \\
\hline Pantex Plant & 0.10 & 0.11 & 0.22 & 78 & 78 & - & 132 & $=$ & 182 & - & - & - & - \\
\hline
\end{tabular}

- Indicates value nor available 
Table 3-5. DOE 5480.28 Performance Criteria (Continued)

\begin{tabular}{|c|c|c|c|c|c|c|c|c|c|c|c|c|c|}
\hline \multirow[b]{2}{*}{ DOE Site } & \multicolumn{3}{|c|}{$\begin{array}{l}\text { Estimated Horizontal Selsmic } \\
\text { Load (g) by DOE 5480.28 } \\
\text { Performance Category (PC) } \\
\end{array}$} & \multicolumn{6}{|c|}{$\begin{array}{l}\text { Wind and Tornado Speeds (MPH) by DOE } 5480.28 \text { Performance } \\
\text { Calegory }\end{array}$} & \multicolumn{4}{|c|}{ Flood (ft above facillity grade) } \\
\hline & $\begin{array}{c}\text { PC 1 } \\
(1 E-3 / y) \\
\end{array}$ & $\begin{array}{c}\text { PC } 2 \\
(5 E-4 / y) \\
\end{array}$ & $\begin{array}{c}\text { PC 3 } \\
(1 E-4 / y)\end{array}$ & $\begin{array}{c}\text { PC I } \\
\text { Wind } \\
(2 E-2 / y) \\
\end{array}$ & $\begin{array}{c}\text { PC 2 } \\
\text { Wind } \\
(2 E-2 / y) \\
\end{array}$ & $\begin{array}{c}\text { PC 3 } \\
\text { Wind } \\
(1 \mathbf{E}-3 / y)\end{array}$ & $\begin{array}{c}\text { PC } 3 \\
\text { Tormado } \\
(2 E-5 / y) \\
\end{array}$ & $\begin{array}{c}\text { PC } 4 \\
\text { Wind } \\
(1 E-4 / y)\end{array}$ & $\begin{array}{c}\text { PC } 4 \\
\text { Toraade } \\
(2 E-6 / y) \\
\end{array}$ & $\begin{array}{c}P C \text { 1 } \\
(1 E \cdot 3 / y) \\
\end{array}$ & $\begin{array}{c}\text { PC: } 2 \\
(5 E-t / y) \\
\end{array}$ & $\begin{array}{c}\text { PC 3 } \\
(1 E \cdot 4 / y) \\
\end{array}$ & $\begin{array}{c}P C+1 \\
(5 E-5 / y) \\
\end{array}$ \\
\hline Pinellas Plant & 0.05 & 0.07 & 0.11 & 93 & 93 & 130 & - & 150 & - & -2 & -1 & 5 & 17 \\
\hline $\begin{array}{l}\text { Portsmouth } \\
\text { Gaseous } \\
\text { Diffusion Plant }\end{array}$ & 0.11 & 0.14 & 0.20 & 70 & 70 & - & 110 & - & 166 & - & - & - & - \\
\hline $\begin{array}{l}\text { Rocky Flats } \\
\text { Plant }\end{array}$ & 0.15 & 0.17 & 0.23 & 109 & 109 & 138 & - & 161 & - & 4 & 5 & 6 & 8 \\
\hline $\begin{array}{l}\text { Sandia NL, New } \\
\text { Mexico }\end{array}$ & 0.22 & 0.28 & 0.47 & 78 & 78 & 93 & - & 107 & - & \multicolumn{4}{|c|}{ No Credible Flood Hazard } \\
\hline $\begin{array}{l}\text { Mexico } \\
\text { Sandia NL. } \\
\text { Califormia }\end{array}$ & 0.48 & 0.56 & 0.9 & 72 & 72 & 96 & - & 113 & - & 2.5 & 3 & 4 & 5 \\
\hline $\begin{array}{l}\text { Savannah River } \\
\text { Plant }\end{array}$ & 0.11 & 0.14 & 0.24 & 78 & 78 & - & 137 & - & 192 & - & - & - & - \\
\hline $\begin{array}{l}\text { Stanford Linear } \\
\text { Accelerator } \\
\text { Center }\end{array}$ & 0.59 & 0.73 & - & 72 & 72 & 95 & - & 112 & - & - & - & - & - \\
\hline $\begin{array}{l}\text { Waste Isolation } \\
\text { Pilot Plant }\end{array}$ & - & - & - & 80 & 80 & - & $<183$ & - & $>183$ & - & - & $\overline{-}$ & - \\
\hline $\begin{array}{l}\text { Yucca Mountain } \\
\text { Project }\end{array}$ & - & - & - & - & - & - & - & - & - & - & - & - & - \\
\hline
\end{tabular}

\footnotetext{
- Indicates value not available
} 


\subsection{FACILITY DESCRIPTION AND OPERATIONS}

\subsection{LOCATION AND DESCRIPTION}

Although environmental characteristics of potential sites can have a significant impact on the design and construction of a vitrification facility, the process itself is not affected by the location and some general criteria for facility design and operation can be postulated. The following subsections details some of the facility design characteristics which will be important to a future facility and to site selection. The design of current lab-scale and pilot scale vitrification units is also described and potential safety systems which may be included in a future facility are discussed.

\subsubsection{Site Location}

The location for installation of a vitrification facility or integrated mixed waste treatment facility including a vitrification unit has not been determined.

\subsubsection{General Building Requirements}

A future vitrification facility or unit in an integrated facility must comply with general building requirements contained in DOE Order 6430.1A (DOE 1989a). Major requirements include the following:

- A building capable of holding the vitrification melter and associated offgas treatment systems.

- An automatic fire suppression system, as the contents of the building will be valued at over \$1 million. The fire suppression system should be of the wet stand pipe design since the building will require climate control. A dry stand pipe system is used only in buildings which are not climate controlled with the possibility of water freezing in the pipes. The fire suppression system must meet National Fire Protection Association (NFPA) 13 Standards for Ordinary Hazards (Group 1 for a Low Hazard Facility and Group 3 for a Moderate Hazard Facility). The fire alarm system must be compatible with the system currently in place at the DOE facility where the vitrification unit is located.

- A domestic water supply of sufficient capacity to provide for the cooling water requirements of the melter and the domestic sanitation needs of building occupants. The domestic water supply system will be a separate system from that used by the fire suppression system.

- A back-up electrical system to maintain operation of the melter and off-gas system in case of power failure. The back-up will allow the unit to either remain in operation or go through a controlled shut down.

- Real-time airbome radioactive material monitoring equipment for both the general work area and the exhaust stack to meet both DOE and EPA requirements 
Primary and secondary containment systems for any radioactive, hazardous or mixed waste which may be spilled or leak out of the system.

\subsubsection{Building Design Requirements}

Building design and structural requirements will depend on whether the operation is classified as low or moderate hazard as defined in DOE 6430.1A (DOE 1989a). Structural and design requirements are based, in part, on earthquake (seismic) activity, wind loading (to include hurricanes and tomadoes), and flooding potential. Design guidelines are contained in UCRL15910 (Kennedy et al. 1990). As discussed in Section 3 of this PHA, updated natural phenomena hazard performance categorization methods and criteria have been and are being developed in association with the issuance of DOE Order 5480.28 (DOE 1993b) and the draft revision of the DOE Design Criteria order, DOE 6430.1B.

The performance goal annual probability of exceedance, as defined in the UCRL, for low hazard and moderate hazard facilities for major structural damage or facility collapse that would endanger personnel within the facility are as follows:

- Low Hazard: annual probability of $5 \times 10^{-4}$ for facility damage to the extent that the facility cannot perform its function

- Moderate Hazard: annual probability of $10^{-4}$ for facility damage to the extent that the facility cannot perform its function.

Design criteria for low and moderate hazard facilities must meet the annual probability of exceedance criteria for earthquake, wind loading, and flooding as described in Table 4-1 below:

Table 4-1. Annual Probability of Exceedance

\begin{tabular}{|l|c|c|}
\hline \multicolumn{1}{|c|}{ Design Item } & Low Hazard & Moderate Hazard \\
\hline Earthquake & $1 \times 10^{-3}$ & $1 \times 10^{-3}$ \\
\hline Wind Loading & $2 \times 10^{-2}$ & $1 \times 10^{-3}$ \\
\hline Tornadoes & Not Applicable & $2 \times 10^{-5}$ \\
\hline Flooding & $5 \times 10^{-4}$ & $1 \times 10^{-4}$ \\
\hline
\end{tabular}

DOE site specific design information for wind loading, flooding, and seismic activity is included in UCRL-15910 (Kennedy et al. 1990) and outlined in Section 3 of this PHA. 


\subsection{GENERAL DESCRIPTION OF OPERATIONS}

\subsubsection{System Description}

Vitrification of waste by joule heating is a newer application of glass melting technology that has been used in industry for many years. Industrial glass melters include both "cold top" and "hot top" melters, the difference being that, in a cold top melter, unmelted feed covers a significant portion of the top of the vessel and, in a hot top melter, the surface of the melt is maintained liquid by external heaters. Both types typically use electrodes in the sides of the vessel to provide primary process heating and require a start-up heat source to initiate processing. A joule-heated melter was evaluated for treatment of high level waste at the proposed Hazardous Waste Treatment Facility (HWTF), at the Hanford site. A draft Preliminary Safety Evaluation Document for the Hazardous Waste Treatment Facility (Pacific Northwest Laboratory 1992) has been issued and provides details of the hazards associated with this type of technology. Many of the hazards and safety considerations applicable to that facility would be applicable to a future vitrification facility or vitrification segment of an integrated mixed waste treatment facility and the Evaluation (PNL 1992) is used as a source of information for this PHA. A Process Hazards Review (Savannah River Laboratory 1988) was performed for the 672-T Integrated Defense Waste Processing Melter Facility and is also used as a source of hazard and safety information for this PHA. Joule melting technology is also being demonstrated at the Savannah River Site for the treatment of M-area mixed wastes as discussed in the Draft Environmental Assessment Treatment of M-Area Mixed Wastes at the Savannah River Site (DOE/SR 1993).

Historically, the efficiency of melting for glass production was constrained by surface heat transfer limitations. The introduction of joule heating technology, where a current is passed through the melt material providing a source of resistive heat, resulted in an increase in energy efficiency and melting productivity. Larger-scale industrial joule melters have been identified as unsuitable for treatment of mixed waste (Richards and Bickford 1990) but serve to demonstrate the viability of the technology and to provide some information with respect to process hazards. feed requirements, off-gas constituents and quantities, process control requirements, etc.

Joule melting technologies are being demonstrated for the Mixed Waste Integrated Program at the Clemson University Industrial Center for Vitrification Research. These are a pilot-scale StirMelter $^{\mathrm{TM}}$ designed by Glasstech, Inc. and an EnVitCo joule melter (Figure 4-1). The StirMelter $^{\mathrm{TM}}$ technology uses an impeller as one of the electrodes, with the other electrode being in the comers of the vessel. The stirred technology allows both an increase in the heat transfer rate at lower temperature and can produce highly mixed and lower density glasses. The rate of 
Figure 4-1. Vitrification Prototypes

ENVITCO EV-16 COLD-TOP MGH TEMPERATURE MELTER

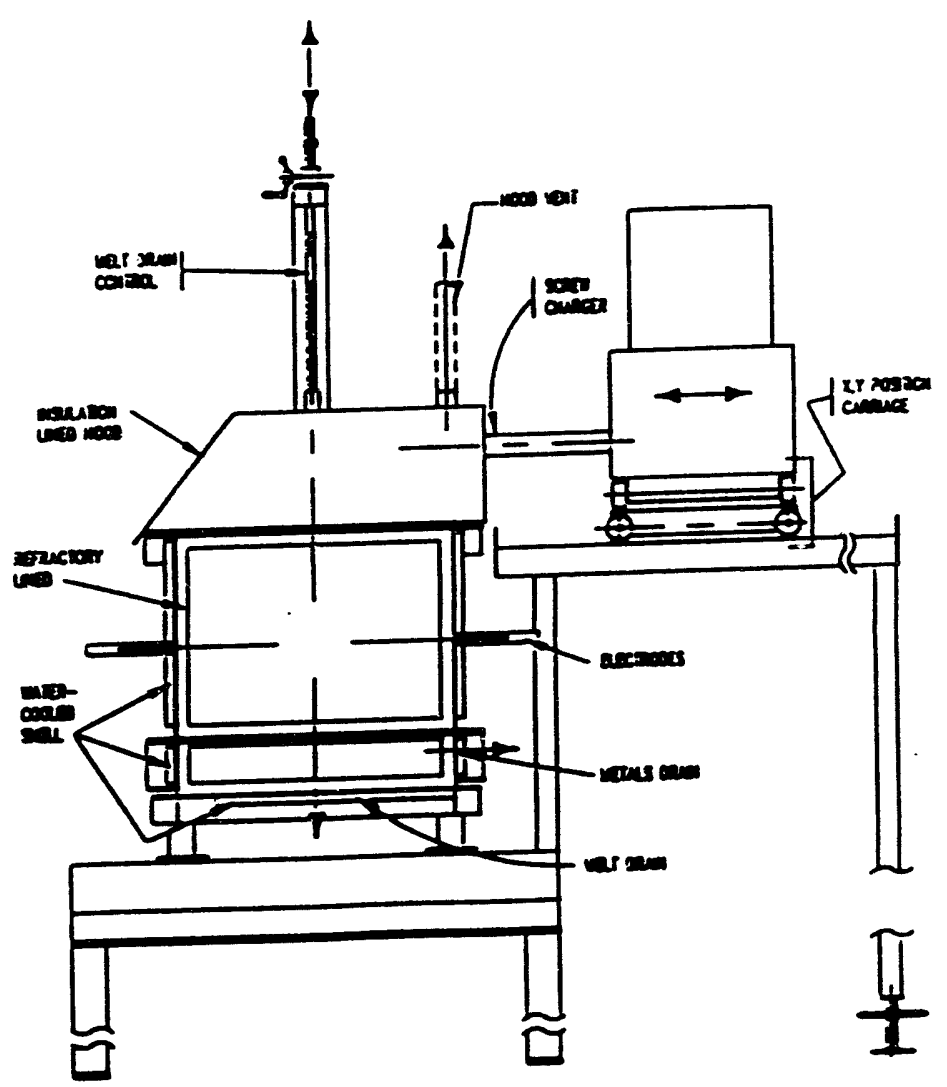

STIR MELTER WV-0.25 STIRRED TANK MELTER

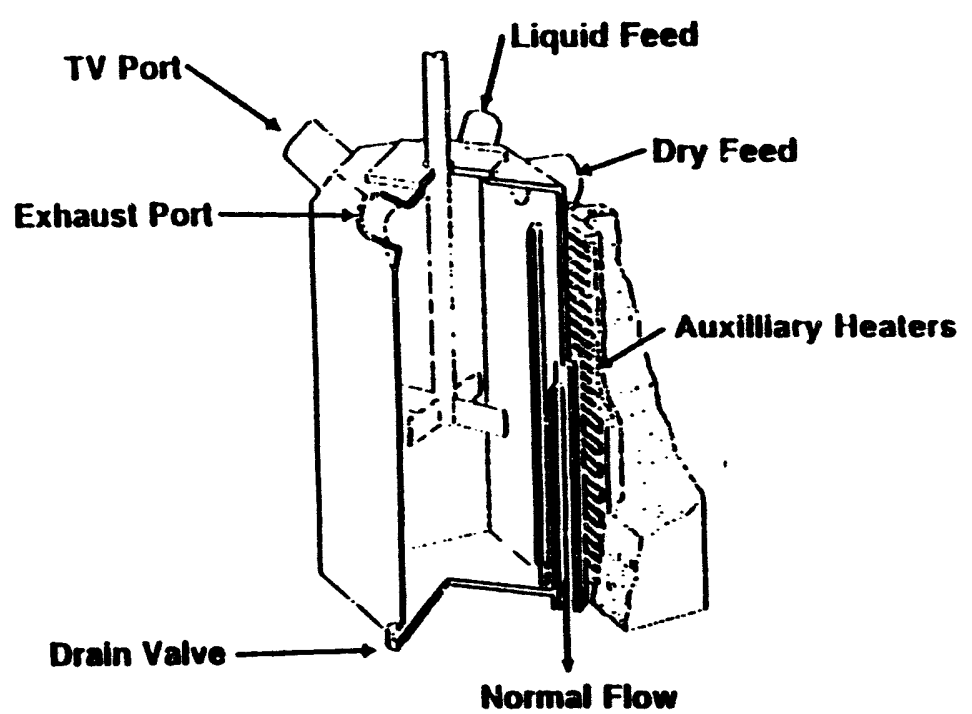


heating in a stirred system is limited by the maximum current density which is a function of impeller surface area. The EnVitCo system is proprietary and no system details were provided for the PHA.

A future mixed waste vitrification system may be similar to the demonstration systems currently under study at the Clemson University facility. Other candidate systems are being developed and teste $\lrcorner$ at the Pacific Northwest Laboratory including the High Temperature Melter. TerraVit ${ }^{\mathrm{TM}}$. VitPac ${ }^{\mathrm{TM}}$, and the Liquid Fed Ceramic Melter.

\subsubsection{Process Description}

Details of the Clemson melters were provided in a private communication by Dalton (1992) from which the following information was taken. The Stir-Melter ${ }^{\mathrm{TM}}$ at the Clemson site is a lab-scale melter constructed of alloy 690 with a melt chamber which is 6" square by I' deep. The melter is auger fed and has a weir type tap for glass removal and a bottom tap for metals removal. It can process approximately $10 \mathrm{lbs}$ per hour and operates at a temperature of $\sim 2,100^{\circ} \mathrm{F}$. Stir-Melter ${ }^{T M}$ also produces larger vitrification units up to 20 square feet in surface area. The EnVitCo joule meiter is built to pilot-scale and is refractory lined. It has an 18 " square chamber and is water cooled. The melter uses molybdenum electrodes mounted in each side wall. The glass tap is a tube that extends from the bottom of the melter into the melt to maintain a minimum level. A bottom tap for metals removal is also incorporated. The melter can process approximately $70 \mathrm{lbs}$ per hour and operates at a temperature of $\sim 3,000^{\circ} \mathrm{F}$. It is slurry fed. The off-gas from the units is sent to a common offgas system operating at a slight negative pressure with flows up to $400 \mathrm{scfm}$. The offgas system consists of a secondary combustion chamber followed by a water/air spray quench, a fiberglass/sand filter, and HEPA filter. No specific safety systems other than the off-gas system were identified as being in use at the Clemson facility.

The DOE MWIP is moving toward demonstration of the vitrification technologies for actual mixed waste at the Westinghouse Savannah River - Clemson site. Demonstration facilities are expected to employ production scale units and to prove the technology both for surrogate wastes and, subsequently, actual wastes. The pilot plants will likely be equipped with additional safety and process systems over and above those in use at the current Clemson facility.

Future melter systems are expected to consist of a bulk material feeder, a primary melt chamber with a collection crucible. pertaps a secondary combustion chamber to assure complete oxidation of volatile effluents from the melt chamber, and exhaust gas pollution control systems. The material for treatment is expected to be continuously fed into the primary chamber, which. like the current demonstration chambers, would be either refractory-lined or alloy 690 vessels. A 
collection crucible is expected to be located at the bottom of the primary chamber in which the molten material from the process would be collected.

Products of incomplete combustion would be drawn from the primary chamber as offgas and may be fed into a secondary chamber where combustion is completed. The exhaust gas would then be cooled before entering the air pollution control system which may include particulate bag filters (bag house), high efficiency particulate air (HEPA) filters, cascade water wash systems, charcoal filters, or other commercial filtration materials. Both the primary and the secondary chambers would be kept under a slight negative pressure by the exhaust fans.

\subsubsection{Required Support Equipment}

A future vitrification facility or facility segment is expected to require support areas including:

- A receiving area for receipt, segregation, and classification of wastes;

- Short-term storage areas which will allow segregated storage of non-compatible wastes or radiological controls and shielding as necessary for the higher activity wastes;

- Processing and preparation areas in which preliminary treatments are performed to prepare the waste for introduction into the vitrification units;

- An off-gas treatment area;

- Post-treatment waste packaging, short-term storage, and shipment area; and

- Other ancillary facilities, such as offices or a laboratory.

Facility services are expected to include building ventilation, process area ventilation which may be HEPA filtered and include carbon absorbers, electrical power (both normal and high voltage) and perhaps back-up diesel power, natural gas to provide building and auxiliary process heating, and water. Other supplies such as compressed gases, compressed air, and supplies of acids or caustics for the off-gas system and waste pre-treatments may be necessary.

\subsection{DESIGN REVIEW}

\subsubsection{Safety Significant Structures}

No safety significant structures have yet been identified for the vitrification melters. Proper application of administrative control procedures should prevent the release of radioactive material in the event of a malfunction within the facility. Structures that could be important to safety, dependent on the inventories of radioactive and hazardous materials in the facility, could include the facility structure (containment), ventilation system, off-gas system, monitoring systems, and process control systems. 


\subsubsection{Structures and Containers}

As the location of a future vitrification facility has not been determined, information on a preliminary building design is not available. Containers which may be used to store waste feed stocks are detailed in Table 4-2. Containers used to store reagents and radioactive materials will likely be required to conform to Department of Transportation (DOT) requirements. Pressure vessels shall conform to current American National Standards Institute (ANSI) specifications.

Table 42. Types of Mixed Waste Containers

\begin{tabular}{|l|l|l|}
\hline & \multicolumn{1}{|c|}{ DOT \# } & \multicolumn{1}{c|}{ Usage } \\
\hline White or yellow 55-gallon drums (polylined) & 6D-2SL & Liquid waste; corrosives \\
\hline White or yellow 55-gallon drums (unlined) & $17 \mathrm{E}$ & Liquid waste; no corrosives \\
\hline 55-gallon steel drums & $17 \mathrm{H}$ & Soils or solids \\
\hline 30-gallon steel drums & $17 \mathrm{C}$ & Soils or solids \\
\hline 30-gallon polyethylene drum & 34 & Liquid waste; oils, solvents, corrosives \\
\hline Fiber boxes & $21 \mathrm{C}$ & Solids \\
\hline 5-gallon lard cans & N/A & Liquid waste; oils, solvents, corrosives \\
\hline 5-gallon polyethylene containers (carboys) & N/A & Liquid waste; oils, solvents, corrosives \\
\hline
\end{tabular}




\subsection{HAZARDS ANALYSIS}

This hazards analysis for vitrification processes follows the requirements of DOE Order 5480.23 (DOE 1992a), DOE Order 5480.21 (DOE 1991d), DOE Order 5480.22 (DOE 1992c), DOE Order 5481.1B (DOE 1986), and the guidance provided in DOE Standands DOE-STD-102792 (DOE 1992b). Consideration is given to the proposed rule 10 CFR 830.110 (DOE 1993a). proposed DOE Safety Guide SG 830.110 (DOE 199lb) and proposed DOE Standard DOE-STD. SAFT-0019 (DOE 1993e), Guidance for Preparation of DOE 5480.22 (TSR) and DOE 5480.23 (SAR) Implementation Plans, in the preparation of this PHA although the proposed regulations and draft guidance have not been approved. A description of the method used in identifying hazards, analyzing events, determining consequences, and assessing risk is presented in Secticn 5.1. Postulated maximum inventories of hazardous and radioactive materials are discussed in Section 5.2 and their use in establishing the preliminary facility hazard classification is described. The basic hazards associated with energy sources and hazardous and radioactive materials which may be present in a vitrification facility or segment of an integrated mixed waste treatment facility and the bounding accident scenarios are discussed and analyzed in Section 5.3. The consequences of these accident scenarios and their use in verifying the preliminary facility hazard classification are discussed in Section 5.4 .

\subsection{HAZARDS ANALYSIS METHOD}

The method used to perform the hazards analysis involves the use of a list of energy sources and materials to identify the hazards and is outlined in Figure 5-1. A team of analysts interviewed project personnel and reviewed available supporting documentation. Records of the characterization of DOE and commercial industry mixed wastes were reviewed to determine the types and quantities of hazardous and radioactive materials that may be treated in a vitrification facility.

Hazards are identified using the "hazardous energy" concept in which potential accidents or abnormal events are distinguished as flows of unwanted energy between a source and a receptor. A hazard source listing specific to a vitrification facility was developed and is presented in Table 5-1.

Potential hazards from energy sources, materials, and natural phenomena are characterized by causes, available preventive features, possible methods of detection, potential mitigative features, and consequences. Preventive features are those aspects of the facility or process which reduce the probability of accident occurrence. Mitigative features are those aspects of the facility or process which reduce the level of consequence of accidents. The results of this stage of the 


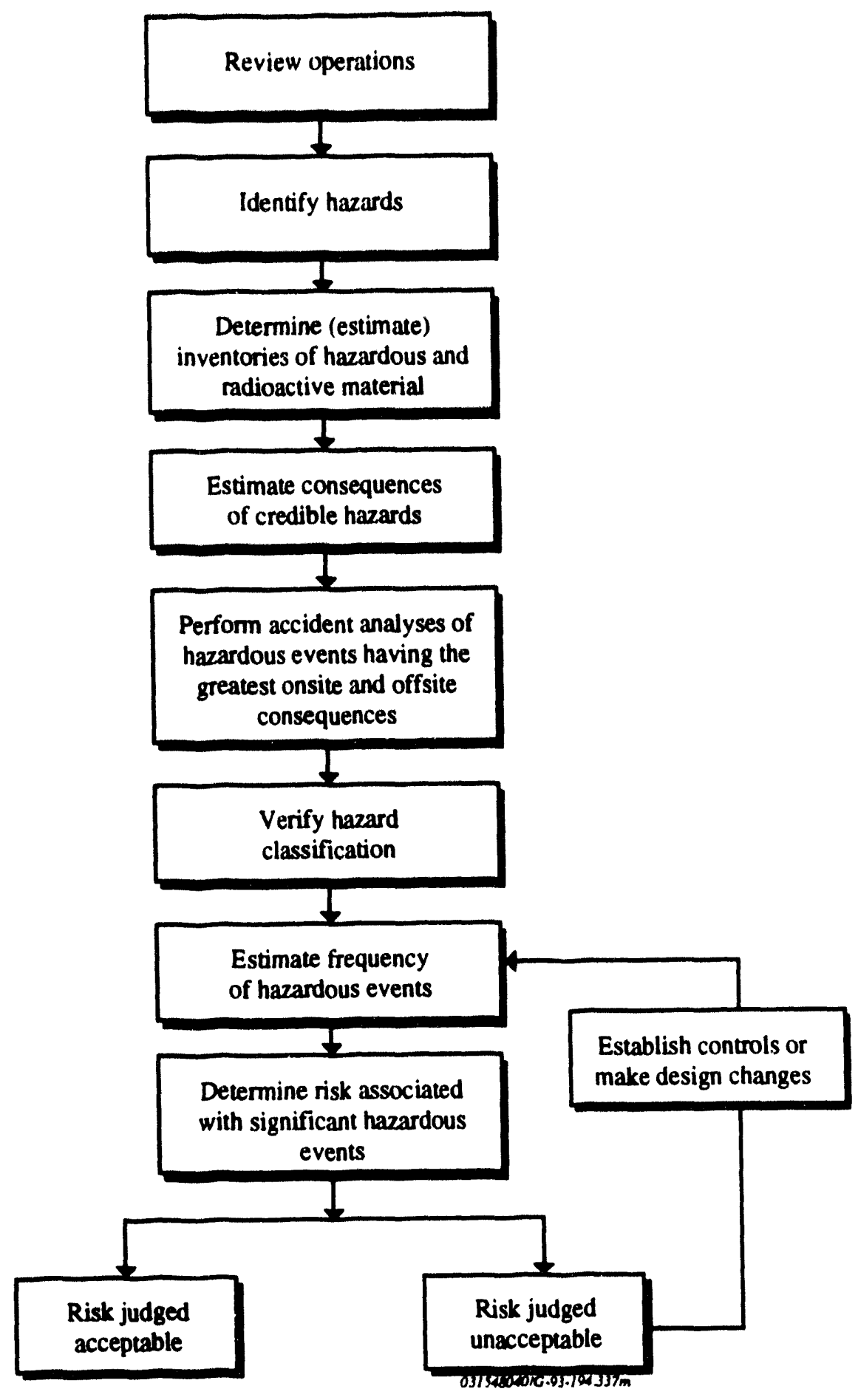

Figure 5.1. Hazard Analysis Process 
Table 5.1. Potential Hazard Sources

\section{Electric Sources}

High voltage and current sources

Transformers

Batteries

Static electricity

Motion Sources

Shears, sharp edges. pinch points, machinery

Vehicles/forklifts \& trucks

Mass in motion

Gravity-Mass Source

Falling

Falling objects

Lifting

Tripping, slipping

Earthquakes

Pressure Sources

Chemical reactions

Noise

Confined gases

Extreme wind

\section{Chemical Sources}

Corrosive materials

Flammable materials

Toxic materials

Reactive materials

Carcinogenic materials

Oxygen deficiency

Heat Sources

Electrical

Melter

Natural gas

Friction

Chemical reactions

Spontaneous combustion

\section{Cold Sources}

Ice, snow

Radiant Sources

Radioactive materials

$R f$ fields

Infrared sources

Ultraviolet 
analysis are provided in Table 5-2. Events which would result in potentially serious on- or offsite consequences are identified. The analyses include events initiated by natural phenomena human error, vehicular accident, explosions, and equipment failures, that could result in adverse on- and offsite consequences due to a fire, explosion, or other mechanism. A qualitative estimate of the probability of occurrence of each hazard is provided together with an appropriate qualitative estimate of the severity of the events. The frequency of industrial accidents is determined from safety statistics compiled by the National Safety Council (1990). These are combined to provide a qualitative risk level for such a facility. These levels are applied in accordance with the method detailed by Hallinan (1988) and are not significantly different from those contained in Pacific Northwest Laboratory Manual PNL-MA-44, Safety Analysis; LA-10294-MS (Elder et. al. 1986); and in the Technical Guidance for Hazards Anatysis (EPA. FEMA \& DOT 1987). The probability and consequence level definitions of Hallinan (1988) are detailed in Tables 5-3 and 5-4. The risk levels are determined by application of the Risk Matrix developed by Hallinan (1988), provided in Figure 5-2.

New criteria are specified in the draft DOE-STD-SAFT-1900 (DOE 1993e) which are significantly different from the criteria used in the other referenced qualitative hazard analysis methods and are not adopted in this PHA. The draft Standard changes the designations of both event frequencies and consequences and presents a different risk table. For example, in the draft Standard events with a frequency of $10^{-4}$ to $10^{-2}$ are designated as being of a "Medium" frequency, rather than "Low" as in the method used herein, and a "Medium" consequence is one in which a serious injury to a worker could occur within the facility rather than a serious injury to a worker outside the facility. In the draft standard a Medium frequency event. such as a fire, and a Medium consequence, a serious worker injury, would result in a "Serious" classification which could be classified as an unacceptable risk and require extensive analysis and mitigative safety systems. If the draft standard were to be adopted by DOE, extensive revision of this and other safety analyses would be required. 
Table 5-2. Hazards Characterization: Vitrification Processes

\begin{tabular}{|c|c|c|c|c|c|c|c|c|}
\hline \multirow[b]{2}{*}{ Hazard Event } & \multirow[b]{2}{*}{ Causes } & \multicolumn{2}{|c|}{ Preventive Features } & \multirow{2}{*}{$\begin{array}{l}\text { Method of } \\
\text { Detection }\end{array}$} & \multicolumn{2}{|c|}{ Mitigative Features } & \multirow{2}{*}{$\begin{array}{l}\text { Potential } \\
\text { Impact }\end{array}$} & \multirow{2}{*}{$\begin{array}{c}\text { Risk } \\
\text { Determination }\end{array}$} \\
\hline & & Design & Administrative & & Design & Administrative & & \\
\hline Fire & $\begin{array}{l}\text { Incompatible } \\
\text { chemicals in } \\
\text { melter; ignition } \\
\text { of combustibles } \\
\text { in storage; natural } \\
\text { gas leak; } \\
\text { personnel error; } \\
\text { elictrical fault. }\end{array}$ & $\begin{array}{l}\text { Approved } \\
\text { combustible } \\
\text { material storage } \\
\text { containers; } \\
\text { facility designed } \\
\text { to exceed UBC; } \\
\text { electrical system } \\
\text { compliance with } \\
\text { NEC. } \\
\end{array}$ & $\begin{array}{l}\text { Facility safety } \\
\text { procedures; } \\
\text { Quality Assurance } \\
\text { Plan; employee } \\
\text { training; } \\
\text { workplace fire } \\
\text { inspections; } \\
\text { ignition source } \\
\text { limitation. } \\
\end{array}$ & $\begin{array}{l}\text { Personnel } \\
\text { observation: } \\
\text { smoke or heat } \\
\text { detectors. }\end{array}$ & $\begin{array}{l}\text { Automatic fire } \\
\text { sprinkler } \\
\text { systems; fire } \\
\text { extinguishers; } \\
\text { local fire } \\
\text { department: } \\
\text { exterior fire } \\
\text { hydrants. }\end{array}$ & $\begin{array}{l}\text { Facility safety } \\
\text { procedures; } \\
\text { employee } \\
\text { training. }\end{array}$ & $\begin{array}{l}\text { Facility damage; } \\
\text { persunnel injury; } \\
\text { potential release } \\
\text { of hasardous and } \\
\text { radiuactive } \\
\text { materials to the } \\
\text { environment. }\end{array}$ & $\begin{array}{l}\text { Probability } \\
\text { Low } \\
\text { Consequencs } \\
\text { Moderate } \\
\text { Risk } \\
\text { Low }\end{array}$ \\
\hline $\begin{array}{l}\text { Hazardous } \\
\text { Materials } \\
\text { Exposure }\end{array}$ & $\begin{array}{l}\text { Vehicle impact; } \\
\text { container drop; } \\
\text { container failure; } \\
\text { personnel errur; } \\
\text { fire; system } \\
\text { leakage; chemical } \\
\text { reaction; system } \\
\text { leakage or failure. }\end{array}$ & $\begin{array}{l}\text { Approved } \\
\text { hazardous material } \\
\text { storage } \\
\text { containers; DOE } \\
6430.1 \mathrm{~A} / \mathrm{ASME} \\
\text { Code process } \\
\text { vessels and } \\
\text { equipment; } \\
\text { ventilation and } \\
\text { off gas treatment } \\
\text { systems. }\end{array}$ & $\begin{array}{l}\text { Facility safety } \\
\text { procedures; } \\
\text { personnel } \\
\text { training; Quality } \\
\text { Assurance Plan; } \\
\text { workplace air } \\
\text { sampling; signs } \\
\text { and postings. }\end{array}$ & $\begin{array}{l}\text { Personnel } \\
\text { observation; } \\
\text { change of process } \\
\text { system indicators; } \\
\text { ventilation or } \\
\text { building air } \\
\text { monitoring. }\end{array}$ & $\begin{array}{l}\text { Ventilation and } \\
\text { offgas treatment } \\
\text { systems; drain } \\
\text { systems; } \\
\text { secondary } \\
\text { containments; } \\
\text { protective } \\
\text { clothing. }\end{array}$ & $\begin{array}{l}\text { Facility safety } \\
\text { procedures. }\end{array}$ & $\begin{array}{l}\text { Facility personnel } \\
\text { exposure to } \\
\text { hazardous } \\
\text { materials; } \\
\text { potential release } \\
\text { of hazardous } \\
\text { materials to the } \\
\text { environment. }\end{array}$ & $\begin{array}{l}\text { Probability } \\
\text { High } \\
\text { Consequence } \\
\text { Extremely Low } \\
\frac{\text { Risk }}{\text { Low }}\end{array}$ \\
\hline $\begin{array}{l}\text { lonizing } \\
\text { Radiation } \\
\text { Exposure }\end{array}$ & $\begin{array}{l}\text { Vehicle impact; } \\
\text { container drop; } \\
\text { container failure; } \\
\text { personnel error; } \\
\text { fire; system } \\
\text { leakage; chemical } \\
\text { reaction; system } \\
\text { leakage or failure. }\end{array}$ & $\begin{array}{l}\text { Approved } \\
\text { radioactive } \\
\text { material storage } \\
\text { containers; DOE } \\
\text { 6430.1 A/ASME } \\
\text { Code process } \\
\text { vessels and } \\
\text { equipment; } \\
\text { shielding; } \\
\text { ventilation and } \\
\text { offgas treatment } \\
\text { systems; } \\
\text { workplace air } \\
\text { sampling; area } \\
\text { radiation } \\
\text { monitoring. }\end{array}$ & $\begin{array}{l}\text { Facility safety } \\
\text { procedures; } \\
\text { personnel } \\
\text { training; Quality } \\
\text { Assurance Plan; } \\
\text { signs and } \\
\text { postings. }\end{array}$ & $\begin{array}{l}\text { Personnel } \\
\text { observation; } \\
\text { change of process } \\
\text { system indicators; } \\
\text { ventilation and } \\
\text { building air } \\
\text { monitoring } \\
\text { indication; area } \\
\text { monitor } \\
\text { indication. }\end{array}$ & $\begin{array}{l}\text { Ventilation and } \\
\text { offgas treatment } \\
\text { systems; drain } \\
\text { systems; } \\
\text { secondary } \\
\text { containments; } \\
\text { protective } \\
\text { clothing. }\end{array}$ & $\begin{array}{l}\text { Facility safety } \\
\text { procedures. }\end{array}$ & $\begin{array}{l}\text { Facility personnel } \\
\text { exposure to } \\
\text { radioactive } \\
\text { material; } \\
\text { potential release } \\
\text { of radioactive } \\
\text { material to the } \\
\text { environment. }\end{array}$ & $\begin{array}{l}\text { Probability } \\
\text { High } \\
\text { Consequence } \\
\text { Extremely Low } \\
\text { Risk } \\
\text { Low }\end{array}$ \\
\hline
\end{tabular}


Table. 5-2 Hazards Characterization: Vitrification Processes (Continued)

\begin{tabular}{|c|c|c|c|c|c|c|c|c|}
\hline \multirow[b]{2}{*}{ Hazard Event } & \multirow[b]{2}{*}{ Causes } & \multicolumn{2}{|c|}{ Preventive Features } & \multirow{2}{*}{$\begin{array}{l}\text { Method of } \\
\text { Detection }\end{array}$} & \multicolumn{2}{|c|}{ Mitigative Features } & \multirow{2}{*}{$\begin{array}{l}\text { Potential } \\
\text { Impact }\end{array}$} & \multirow{2}{*}{$\begin{array}{c}\text { Risk } \\
\text { Determination }\end{array}$} \\
\hline & & Design & Administrative & & Design & Administrative & & \\
\hline $\begin{array}{l}\text { High Voltage } \\
\text { Hazard }\end{array}$ & $\begin{array}{l}\text { Vehicle impact; } \\
\text { personnel error; } \\
\text { equipment fallure. }\end{array}$ & $\begin{array}{l}\text { Enclosures for } \\
\text { high voltage } \\
\text { equipment; NEC } \\
\text { compliance; } \\
\text { circuit breakers; } \\
\text { grounded conduits; } \\
\text { process system } \\
\text { electrical } \\
\text { indicators. }\end{array}$ & $\begin{array}{l}\text { Facility safety } \\
\text { procedures; } \\
\text { employee } \\
\text { training; } \\
\text { protective shoes } \\
\text { and mats; Quality } \\
\text { Assurance Plan; } \\
\text { signs, tags, and } \\
\text { postings. }\end{array}$ & $\begin{array}{l}\text { Personnel } \\
\text { detection; } \\
\text { electrical system } \\
\text { fault indication; } \\
\text { circuit breaker } \\
\text { trip; detection of } \\
\text { electrical fire. }\end{array}$ & Circuit breakers. & $\begin{array}{l}\text { Facility safety } \\
\text { procedures. }\end{array}$ & $\begin{array}{l}\text { Personnel injury; } \\
\text { equipment } \\
\text { damage; facility } \\
\text { damage. }\end{array}$ & $\begin{array}{l}\text { Probability } \\
\text { Extremely Low } \\
\text { Consequence } \\
\text { Moderate } \\
\text { Risk } \\
\text { Negligible }\end{array}$ \\
\hline $\begin{array}{l}\text { Industrial Hazards } \\
\text { (mass-in-motion) }\end{array}$ & $\begin{array}{l}\text { Forklift } \\
\text { operation; roll-up } \\
\text { doors; crane } \\
\text { operation; } \\
\text { rotating } \\
\text { machinery; fall } \\
\text { from height; } \\
\text { dropped object. }\end{array}$ & $\begin{array}{l}\text { Machinery meets } \\
\text { applicable ANSI } \\
\text { standards; } \\
\text { machine guarding; } \\
\text { hand rails; load- } \\
\text { rated floor; } \\
\text { seismic restraints; } \\
\text { audible and visual } \\
\text { crane alarms; } \\
\text { audible and visual } \\
\text { forklift alarms. }\end{array}$ & $\begin{array}{l}\text { Facility safety } \\
\text { procedures; } \\
\text { Quality Assurance } \\
\text { Plan; employee } \\
\text { training; } \\
\text { preventive } \\
\text { maintenance; } \\
\text { forklift and crane } \\
\text { operator } \\
\text { certifications; } \\
\text { signs and } \\
\text { postings; } \\
\text { personal } \\
\text { protective } \\
\text { equipment } \\
\text { (harness, hard } \\
\text { hats). }\end{array}$ & $\begin{array}{l}\text { Personnel } \\
\text { observation. }\end{array}$ & None identified. & $\begin{array}{l}\text { Facility safety } \\
\text { procedures; } \\
\text { employee } \\
\text { training. }\end{array}$ & $\begin{array}{l}\text { Personnel injury; } \\
\text { equipment } \\
\text { damage; facility } \\
\text { dainage. }\end{array}$ & $\begin{array}{l}\text { Probability } \\
\text { Low to Moderate } \\
\text { Consequence } \\
\text { Moderate to Low } \\
\frac{\text { Risk }}{\text { Low }}\end{array}$ \\
\hline $\begin{array}{l}\text { Natural } \\
\text { Phenomena }\end{array}$ & $\begin{array}{l}\text { Earthquake - } \\
\text { container failure, } \\
\text { building collapse; } \\
\text { tornado - airborne } \\
\text { missile, } \\
\text { building/system } \\
\text { damage; flood - } \\
\text { electrical short, } \\
\text { storage container } \\
\text { failure. }\end{array}$ & $\begin{array}{l}\text { Facility designed } \\
\text { to UBC and DOE } \\
6430.1 \text { A criteria. }\end{array}$ & $\begin{array}{l}\text { Facility safety } \\
\text { procedure: } \\
\text { Quality Assurance } \\
\text { Plan; personnel } \\
\text { training. }\end{array}$ & $\begin{array}{l}\text { Personnel } \\
\text { observation; } \\
\text { Report of } \\
\text { inclement } \\
\text { weather. }\end{array}$ & None identified. & $\begin{array}{l}\text { Facility safety } \\
\text { procedures; } \\
\text { personnel } \\
\text { training. }\end{array}$ & $\begin{array}{l}\text { Personnel injury: } \\
\text { equipment } \\
\text { damage; facility } \\
\text { damage; potential } \\
\text { release of } \\
\text { hazardous and } \\
\text { radioactive } \\
\text { material to the } \\
\text { environment. }\end{array}$ & $\begin{array}{l}\text { Probability } \\
\text { Extremely Low to } \\
\text { Moderate } \\
\text { Consequence } \\
\text { Moderate to } \\
\text { Negligible } \\
\text { Risk } \\
\text { Negligible to Low }\end{array}$ \\
\hline
\end{tabular}


Table. 5-2 Hazards Characterization: Vitrification Processes (Continued)

\begin{tabular}{|c|c|c|c|c|c|c|c|c|}
\hline \multirow[b]{2}{*}{ Hazard Event } & \multirow[b]{2}{*}{ Causes } & \multicolumn{2}{|c|}{ Preventive Features } & \multirow{2}{*}{$\begin{array}{l}\text { Method of } \\
\text { Detection }\end{array}$} & \multicolumn{2}{|c|}{ Mitigative Features } & \multirow{2}{*}{$\begin{array}{l}\text { Potential } \\
\text { Impact }\end{array}$} & \multirow{2}{*}{$\begin{array}{c}\text { Risk } \\
\text { Determination }\end{array}$} \\
\hline & & Design & Administrative & & Design & Administrative & & \\
\hline Aircraft Impact & $\begin{array}{l}\text { Aircraft crash into } \\
\text { facility - system } \\
\text { damage/failure; } \\
\text { fire; explosion }\end{array}$ & $\begin{array}{l}\text { Facility designed } \\
\text { to UBC and DUE } \\
\text { 6430.1A criteria. }\end{array}$ & $\begin{array}{l}\text { Facility safety } \\
\text { procedures; } \\
\text { Quality Assurance } \\
\text { Plan; personnel } \\
\text { Iraining. }\end{array}$ & $\begin{array}{l}\text { Personnel } \\
\text { observation }\end{array}$ & None identified & $\begin{array}{l}\text { Facility safety } \\
\text { procedures; } \\
\text { personnel training }\end{array}$ & $\begin{array}{l}\text { Personnel injury; } \\
\text { equipment } \\
\text { damage; facility } \\
\text { damage; potential } \\
\text { release of } \\
\text { hazardous and } \\
\text { radioactive } \\
\text { material to the } \\
\text { environment. } \\
\end{array}$ & $\begin{array}{l}\text { Probability } \\
\text { Extremely Low to } \\
\text { Low } \\
\text { Consequence } \\
\text { High to Moderate } \\
\text { Bisk } \\
\text { Low }\end{array}$ \\
\hline Explosion & $\begin{array}{l}\text { Incompatible } \\
\text { chemicals in } \\
\text { melter; } \\
\text { uncontrolled } \\
\text { chemical reaction } \\
\text { in melter; } \\
\text { pressurized gas or } \\
\text { system failure; } \\
\text { buildup of } \\
\text { explosive gas; } \\
\text { natural gas leak. }\end{array}$ & $\begin{array}{l}\text { Facility designed } \\
\text { to DOE } 6430.1 \mathrm{~A} \text {, } \\
\text { ASME code; } \\
\text { combustible gas } \\
\text { detection. }\end{array}$ & $\begin{array}{l}\text { Facility safety } \\
\text { procedures; } \\
\text { Quality Assurance } \\
\text { Plan; personnel } \\
\text { training. }\end{array}$ & $\begin{array}{l}\text { Personnel } \\
\text { observation; } \\
\text { process indicator } \\
\text { changes. }\end{array}$ & $\begin{array}{l}\text { Shielding; } \\
\text { venting. }\end{array}$ & $\begin{array}{l}\text { Facility safety } \\
\text { procedures; } \\
\text { personnel } \\
\text { training. }\end{array}$ & $\begin{array}{l}\text { Personnel injury; } \\
\text { equipment } \\
\text { damage; facility } \\
\text { damage; potential } \\
\text { release of } \\
\text { radioactive and } \\
\text { hazardous material } \\
\text { to the } \\
\text { environment. }\end{array}$ & $\begin{array}{l}\text { Probability } \\
\text { Low } \\
\text { Consequence } \\
\text { Moderate } \\
\text { Risk } \\
\text { Low }\end{array}$ \\
\hline $\begin{array}{l}\text { Thermal Sources } \\
\text { (Heat and Cold) }\end{array}$ & $\begin{array}{l}\text { Container failure; } \\
\text { process system } \\
\text { leakage/failure. }\end{array}$ & $\begin{array}{l}\text { Facility designed } \\
\text { to DOE 6430.1 A, } \\
\text { ASME code; } \\
\text { access } \\
\text { restrictions; } \\
\text { insulation. }\end{array}$ & $\begin{array}{l}\text { Facility safety } \\
\text { procedures; } \\
\text { employee } \\
\text { training; signs, } \\
\text { tags, and } \\
\text { postings. }\end{array}$ & $\begin{array}{l}\text { Personnel } \\
\text { observation; } \\
\text { process system } \\
\text { indicator changes. }\end{array}$ & $\begin{array}{l}\text { Personal } \\
\text { protective } \\
\text { equipment. }\end{array}$ & $\begin{array}{l}\text { Facility safety } \\
\text { procedures; } \\
\text { personnel } \\
\text { training. }\end{array}$ & Personnel injury. & $\begin{array}{l}\text { Probability } \\
\text { Moderate } \\
\text { Consequence } \\
\text { Low } \\
\text { Risk } \\
\text { Low }\end{array}$ \\
\hline
\end{tabular}


Table 5-3. Probability Levels.

\begin{tabular}{|c|c|c|c|}
\hline \multicolumn{2}{|c|}{ Probability Level } & $\begin{array}{c}\text { Estimate Range } \\
\text { of Occurrence } \\
\text { Rate per Year }\end{array}$ \\
\hline Category & Symbol & \multicolumn{1}{|c|}{ Description } & $<10^{-6}$ \\
\hline Incredible & A & $\begin{array}{l}\text { Probability of occurrence is so small that } \\
\text { a reasonable scenario is not conceivable. } \\
\text { These events are not considered in design } \\
\text { or accident analysis. }\end{array}$ & \\
\hline Extremely Low & B & $\begin{array}{l}\text { Probability of occurrence is extremely } \\
\text { unlikely or event is not expected to occur } \\
\text { during the life of the facility or operation. }\end{array}$ & $>10^{-6}$ and $<10^{-4}$ \\
\hline Low & C & $\begin{array}{l}\text { Probability of occurrence is unlikely, or } \\
\text { event is not expected to occur but may } \\
\text { occur during the life of the facility or } \\
\text { operation. }\end{array}$ & $>10^{-4}$ and $<10^{-2}$ \\
\hline Moderate & D & $\begin{array}{l}\text { Event is likely to occur during the facility } \\
\text { or operation lifetime. }\end{array}$ & $>10^{-2}$ and $<10^{-1}$ \\
\hline High & E & $\begin{array}{l}\text { Event is likely to occur several times } \\
\text { during the facility or operation lifetime. }\end{array}$ & $>10^{-1}$ \\
\hline
\end{tabular}

Table 5-4. Consequence Levels.

\begin{tabular}{|c|c|l|}
\hline $\begin{array}{c}\text { Consequence } \\
\text { level }\end{array}$ & Category & \multicolumn{1}{c|}{ Maximum Consequences } \\
\hline 1 & High & $\begin{array}{l}\text { Serious impact on-site or off-site. May cause death or loss of the } \\
\text { facility/operation. Major impact on the environment. }\end{array}$ \\
\hline 2 & Moderate & $\begin{array}{l}\text { Major impact on-site and/or minor impact off-site. May cause } \\
\text { severe injury or severe occupational illness to personnel or major } \\
\text { damage to a facility/operation or minor impact to the environment. } \\
\text { Capable of returning to operation. }\end{array}$ \\
\hline 3 & Low & $\begin{array}{l}\text { Minor on-site with no off-site impact. May cause minor injury or } \\
\text { minor occupational illness, or minor impact on the environment. }\end{array}$ \\
\hline 4 & $\begin{array}{c}\text { Exuremely } \\
\text { Low }\end{array}$ & $\begin{array}{l}\text { Will not result in a significant injury, occupational illness, or } \\
\text { impact on the environment. }\end{array}$ \\
\hline
\end{tabular}

a Worker consequence levels addressed in this table are for workers outside the immediate area in which an accident occurs. 

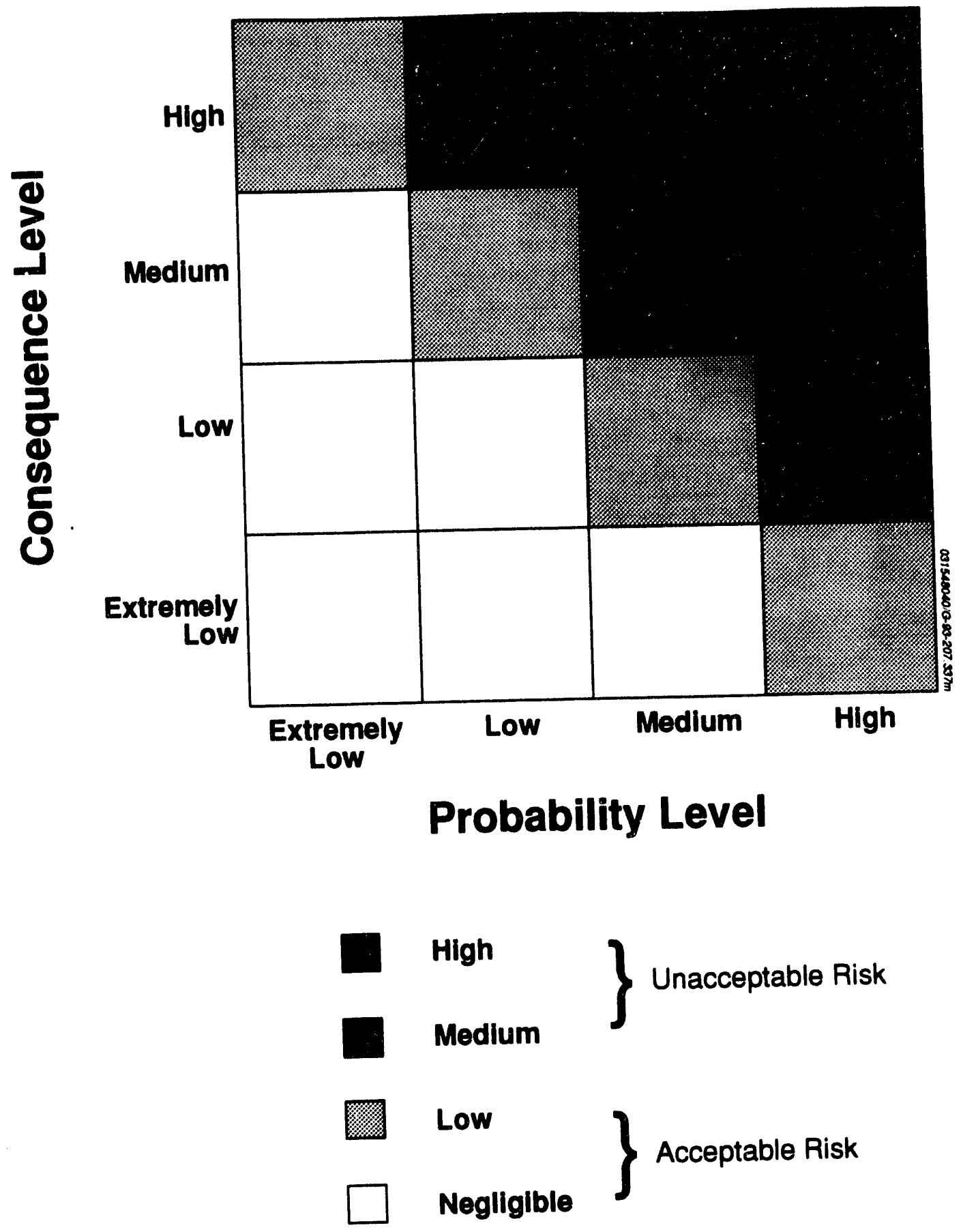

Figure 5-2. Risk Matrix 


\subsection{INVENTORIES}

\section{Radioactive Material}

In accordance with the guidance of DOE-STD-1027-92 (DOE 1992b), a preliminary assessment of facility hazard requires the identification of the inventory of radioactive material and a comparison to the Threshold Quantities provided in the Standard.

A wide range of potential radioisotopes may be found in mixed waste but most exist at low concentrations. Mixed waste containing fissile transuranic isotopes may be treated in the facility although it is expected that these materials will meet the "less than $100 \mathrm{nCi} / \mathrm{g}$ " standard for handling as low-level wastes in accordance with DOE Order 5820.2A (DOE 1988b) and, therefore, there will be no possibility of a nuclear criticality at the facility. Should enriched uranium or fissile transuranic wastes he processed at a vitrification facility, inventory limits in accordance with the standards of ANSL/ANS-8.15-1981 (ANSI 1981) and ANSI/ANS-.8.1-1983 (ANSI 1983) shall be established so that nuclear criticality will not be possible. Facility maximum inventory limits shall be established in facility safety procedures for all classes of radioisotopes to support maintenance of the ultimate facility hazard classification and assure the prevention of unreviewed safety questions (USQs) in accordance with the requirements of DOE Order 5480.21 (DOE 1991d).

An inventory determination is performed by estimating the total quantity of each class of radionuclide allowable in the facility mixed waste inventory based on the DOE-STD-1027-92, Table A.1. Threshold Quantities. The sum of the ratios of the total inventory of each radionuclide to the Table A.l thresholds are then calculated. Representative and conservative radioisotopes are chosen in the broad categories of activation and fission products, iodines, natural actinides, and transuranics. These choices reflect both the lowest or one of the lowest Threshold Quantities in the DOE Standard and isotopes typically found in mixed waste. The results are provided for a vitrification facility which is operated as an Exempt facility (that is, a facility which has radiological hazards, but does not meet the criteria for consideration as a "nuclear" facility and is exempt from the requirements of DOE 5480.23), a Category 3 facility, or a Category 2 facility, in accordance with the guidance of DOE-STD-1027-92. The ultimate classification depends on the inventories of radioactive materials in the wastes being processed. The maximum inventory for an Exempt facility is estimated in Table 5-5. The maximum inventory for a Category 3 facility is estimated in Table 5-6. A facility which would have an inventory in excess of the Category 3 estimated limits of Table 5-6 would be considered Category 2 . 
Table 5-5 Proposed Maximum Radionuclide Inventory for an Exempt (Below Category 3) Facility

\begin{tabular}{|c|c|c|c|}
\hline Nuclide ${ }^{2}$ & $\underset{\text { Inventöry }(\mathbf{C i})^{\mathbf{b}}}{\operatorname{Maximum}}$ & $\begin{array}{c}\text { Category } 3 \\
\text { Threshold Quantity } \\
\text { (Ci) C }\end{array}$ & $\begin{array}{c}\text { Inventory to } \\
\text { Threshold } \\
\text { Quantity Ratiod }\end{array}$ \\
\hline Tritium $\left({ }^{3} \mathrm{H}\right)$ & 100 & 1,000 & 0.1 \\
\hline${ }^{14} \mathrm{C}$ & 4 & 420 & 0.01 \\
\hline $\begin{array}{l}\text { Activation Products } \\
\left({ }^{60} \mathrm{Co}\right)\end{array}$ & 28 & 280 & 0.1 \\
\hline Fission Products $\left({ }^{90} \mathrm{Sr} / \mathrm{Y}\right)$ & 1.6 & 16 & 0.1 \\
\hline Iodines $(125 \mathrm{I})$ & 0.05 & 0.56 & 0.1 \\
\hline Thorium $(232 \mathrm{Th})$ & 0.01 & 0.1 & 0.1 \\
\hline Uranium $(238 \mathrm{U})$ & 0.4 & 4.2 & 0.1 \\
\hline Transuranics $\left({ }^{239} \mathrm{Pu}\right)$ & 0.05 & 0.52 & 0.1 \\
\hline \multicolumn{3}{|l|}{ Sum of Ratios } & 0.71 \\
\hline
\end{tabular}

a The nuclides indicated are examples chosen as representative of a particular class of nuclides.

b The maximum inventory quantities postulated are the maximum total quantities of those classes of isotopes which would be allowed into a vitrification facility and include all wastes, in-process materials, and process by-products.

c The Threshold Quantities are as indicated in DOE-STD-1027-92 (DOE 1992b).

d The ratios of the maximum inventory quantities to the Category 3 Threshold Quantities are summed, in accordance with the guidance in DOE-STD-1297-92, and are found to be less than 1.0. This demonstrates that the potential hazard from the maximum inventory of radioactive material will not be sufficient to warrant classification as Category 3.

Table 5-6 Proposed Maximum Radionuclide Inventory for a Category 3 Facility

\begin{tabular}{|c|c|c|c|}
\hline Nuclide $^{\mathrm{a}}$ & $\begin{array}{c}\text { Maximum } \\
\text { Inventory }(\mathrm{C} i)^{b}\end{array}$ & $\begin{array}{c}\text { Category 2 } \\
\text { Threshold Quantity } \\
\text { (Ci) }\end{array}$ & $\begin{array}{c}\text { Inventory to } \\
\text { Threshold } \\
\text { Quantity Ratiod }\end{array}$ \\
\hline Tritium $\left({ }^{3} \mathrm{H}\right)$ & 30,000 & 300,000 & 0.1 \\
\hline${ }^{14} \mathrm{C}$ & 14,000 & $1,400,000$ & 0.01 \\
\hline Activation Products $\left({ }^{60} \mathrm{Co}\right)$ & 19,000 & 190,000 & 0.1 \\
\hline Fission Products $\left({ }^{90} \mathrm{Sr} / \mathrm{Y}\right)$ & 2.200 & 22,000 & 0.1 \\
\hline Iodines $(125 \mathrm{I})$ & 240 & 2,400 & 0.1 \\
\hline Thorium $(232 \mathrm{Th})$ & 1.8 & 18 & 0.1 \\
\hline Uranium $(238 \mathrm{U})$ & 24 & 240 & 0.1 \\
\hline Transuranics $(239 \mathrm{Pu})$ & 5.6 & 56 & 0.1 \\
\hline \multicolumn{3}{|l|}{ Sum of Ratios } & 0.71 \\
\hline
\end{tabular}

a The nuclides indicated are examples chosen as representative of a particular class of nuclides.

b The maximum inventory quantities postulated are the maximum total quantities of those classes of isotopes which would be allowed into a vitrification facility and include all wastes, in-process materials, and process by-products.

c The Threshold Quantities are as indicated in DOE-STD-1027-92 (DOE 1992b).

d The ratios of the maximum inventory quantities to the Category 2 Threshold Quantities are summed, in accordance with the guidance in DOE-STD-1027-92, and are found to be less than 1.0. This demonstrates that the potential hazard from the maximum inventory of radioactive material will not be sufficient to warrant classification as Category 2. 
The sum of the ratios of the total inventory of each radionuclide to the DOE-STD-1027-92. Table A.1, Threshold Quantities is calculated in Tables 5-5 and 5-6 and is less than one in order to provide a margin of safety and preclude approach to any technical safety limit. It should be noted that the vitrification facility or segment of an integrated mixed waste treatment facility should not, at any time, be expected to contain a significant fraction of the maximum inventories. This will maintain a margin of safety, maintain the conservatism of this analysis, and assure that there will be no significant potential for the occurrence of an USQ.

\section{Hazardous Material}

The preliminary assessment of facility hazard is performed in accordance with the requirements of DOE Order 5481.1B (DOE 1986) by examining the range of hazardous materials found in mixed waste and the process reagents and by-products. The hazard classification system contained in DOE Order 5481.1B for facilities containing hazardous (chemical) materials is not yet provided with specific guidance on the evaluation of hazards and consequences, as is contained in DOE-STD-1027-92 (DOE 1992b) for radioactive materials. The Order provides general, qualitative classifications for DOE hazardous facilities similar but not identical to those in DOE Order 5480.23 and DOE-STD-1027-92:

- Low hazard - those which present minor onsite and negligible offsite impacts

- Moderate hazard - those which present considerable potential onsite impacts, but at most minor offsite impacts

- High hazard - those with the potential for onsite or offsite impacts to large numbers of persons or major impacts on the environment.

However, the proposed DOE Standard DOE-STD-SAFT-0019 (DOE 1993e) proposes that the following criteria be used:

- High consequence - > ERPG-2 at the site boundary or > ERPG-3 at $600 \mathrm{~m}$ or prompt death in facility

- Medium consequence- Serious injury in facility

- Low consequence - $\quad<$ High to the public and $<$ Medium to workers

The draft guidance is significantly different from that in the existing DOE Order and other hazard analysis methods in that serious consequences to workers within the facility are considered and could result in the facility being classified as moderate or high hazard. The draft guidance is not used in this analysis and the adoption of the draft guidance would necessitate the revision of this PHA. 
Hazardous materials, for the purpose of this PHA, are considered to be those chemicals which could present a significant hazard to on- or offsite personnel if they were released in sufficient quantity and are those materials which have been designated by the Department of Labor (DOL), Occupational Safety and Health Administration (OSHA), as highly hazardous in 29 CFR 1910.119 (DOL 1993) and by the Environmental Protection Agency (EPA) as extremely hazardous substances in 40 CFR 355 (EPA 1993).

The total quantity of a specific hazardous material in mixed wastes which could be treated by vitrification are estimated below. The maximum amounts of in-process hazardous by-products are estimated. The primary hazardous constituents are identified. These are compared to the referenced industry standards.

The hazardous constituents and quantities of mixed waste generated and stored at the various DOE facilities have not been fully characterized. The range of hazardous constituents which may be incorporated in waste which may be brought into a vitrification facility will likely include all the EPA waste codes except the "K" code (Musgrave 1993). Waste codes D, F, P, and $\mathrm{U}$ represent the following waste categories:

D Codes: Hazardous wastes that show toxicity characteristic, and are subject to Land Disposal Restrictions (LDR) - including D004-D043

F Codes: Hazardous wastes from non-specific sources - including F001 - F039

P Codes: Hazardous wastes from discarded commercial chemical products, offspecification species, container residues and spill residues thereof - including U001-U359 (40 CFR 261.33)

U Codes: Hazardous wastes from discarded commercial chemical products, offspecification species, container residues, and spill residues thereof including P023-P122 (40 CFR 261.33).

Thompson (1992), under contract to the Mixed Waste Treatment Project (MWTP) to prepare Functional and Operational Requirements (F\&OR), has identified mixed waste generated and stored by DOE facilities, using data derived from the following three sources:

- Waste Management Information System

- Integrated Database

- National Report on Prohibited Wastes.

Thompson used the data to categorize DOE mixed waste in five major treatment groups and assigned treatment line/waste codes to these five groups. Pertinent data for these groups include the information summarized in Table 5-7. 
Table 5-7. DOE Mixed Waste Composition by Type

\begin{tabular}{|c|l|c|c|c|}
\hline Waste Code & \multicolumn{1}{|c|}{ Waste Description } & $\begin{array}{c}\text { Density** } \\
\mathbf{k g} / \mathbf{m}^{\mathbf{3}}\end{array}$ & $\begin{array}{c}\text { Mass } \\
\text { Generation } \\
\text { Rate } \mathbf{k g} / \mathbf{y}\end{array}$ & $\begin{array}{c}\text { Volume } \\
\text { Storage Rate } \\
\mathbf{m}^{\mathbf{3}} / \mathbf{y}\end{array}$ \\
\hline 100 & Aqueous liquids & 1,049 & 104,910 & 100 \\
\hline 200 & Organic liquids & 882 & 52,890 & 60 \\
\hline 300 & Wet solids & 1,276 & 957,230 & 750 \\
\hline 400 & Homogeneous dry solid & 1,181 & 88,570 & 75 \\
\hline 500 & Heterogeneous dry solid* & 1,336 & 308,560 & 250 \\
\hline TOTALS & & & $1,512,250$ & 1,160 \\
\hline
\end{tabular}

* This represents the average of the small and large heterogeneous dry solids.

** The average density was $1.25 \mathrm{E} 3 \mathrm{~kg} / \mathrm{m}^{3}$.

Specific components of the five groups which may be contaminated with hazardous constituents from some or all of the EPA waste codes are listed below.

- Aqueous waste may contain the following:

- aqueous liquids

- heavy metal solutions

- $\quad$ salt solutions

- slumies

- trace organics

- Organic liquids may contain the following:

- organic liquids and sludges

- solvents

- scintillation cocktails

- mercury-contaminated liquids

- PCB-contaminated liquids

- Wet solids may contain the following:

- adsorbed/absorbed liquids

- sludges

- resins

- cemented sludges

- Homogeneous solids may consist of the following:

- dry homogeneous solids

- grouts

- ashes and paint chips

- concrete or asphalt

- bricks, soils, and salts

- pyrophorics

- Heterogeneous dry solids may consist of the following:

- equipment

- gloveboxes

- leaded gloves and aprons

- construction debris

- general metals and metallic equipment

- wood

- dry solids which can be sorted 
- filters

- glass

- combustible materials

- miscellaneous waste combinations.

Bechtel Corporation (1992), under contract to MWTP to prepare a cost estimate report. used the same grouping (aqueous liquids, organic liquids, wet solids, homogeneous dry solids. and heterogeneous dry solids) of mixed waste in their study on mixed waste to be treated.

From a list of 125 waste descriptions compiled from the Waste Management Information System for DOE mixed waste, the wastes were organized by Bechtel into the following nine major classes:

\begin{tabular}{ll} 
Class & Waste_Descrintion \\
\hline 1000 & Aqueous liquids and slurries \\
2000 & Organic liquids \\
3000 & Solid process residues \\
4000 & Soils \\
5000 & Debris wastes \\
6000 & Special wastes \\
7000 & Inherently hazardous wastes \\
8000 & Unknown \\
9000 & Treated wastes
\end{tabular}

Examples of waste belonging to each class are provided in "Waste Stream Definition" (Mayberry 1993). Hazardous characteristics of these waste streams include ignitability. corrosivity, reactivity, and toxicity and are exemplified by non-halogenated solvents, acids and bases, cyanides, and halogenated/heavy metals, respectively. From these, standardized surrogate waste streams are being developed for testing under the MWIP (Mayberry et al. 1994). These surrogate streams as detailed by Mayberry et al. are shown in Table 5-8.

The primary contaminants in these surrogates are halogenated and non-halogenated solvents and metals. From these twelve mixed waste surrogates will be selected the standard wastes for testing by vitrification. No specific information could be obtained on the actual surrogate waste streams to be tested by vitrification processes. However, the melter processes are amenable to treating metals and ashes and sludges from other processes. Therefore, four waste streams were selected from Table 5-8 as potential surrogate waste streams for treatment by vitrification processes and these are detailed in Table 5-9. These four waste streams are ash; high organic content sludge; cement, sludges, ashes, solids; and heterogeneous debris. Specific hazardous chemical 
Table 5-8. Mixed Waste Treatment Project Waste Stream Categories Selected for Surrogate Formulations

\begin{tabular}{|c|c|c|c|c|c|c|}
\hline \multirow{2}{*}{ Item } & \multirow{2}{*}{$\begin{array}{l}\text { Code } \\
\text { No. }\end{array}$} & \multirow{2}{*}{$\begin{array}{l}\text { Waste } \\
\text { Name }\end{array}$} & \multirow{2}{*}{$\begin{array}{c}\text { Waste } \\
\text { Description }\end{array}$} & \multicolumn{2}{|c|}{ Poteatial Hazards } & \multirow{2}{*}{$\begin{array}{c}\text { Typical } \\
\text { Hazardous } \\
\text { Constlicuents }\end{array}$} \\
\hline & & & & $\begin{array}{c}\text { Hazard } \\
\text { Class }\end{array}$ & EPA Codes & \\
\hline 1 & 1300 & $\begin{array}{l}\text { Neutral } \\
\text { aqueous wastes }\end{array}$ & $\begin{array}{l}\text { Aqueous solutions or } \\
\text { slurries with pH values } \\
\text { between } 2 \text { and } 12.5\end{array}$ & Toxicity & $\begin{array}{l}\mathrm{F} 001, \mathrm{~F} 003, \\
\mathrm{~F} 006, \mathrm{D} 004- \\
\mathrm{D} 011\end{array}$ & $\begin{array}{l}\text { Volatile and semi- } \\
\text { volatile organics; } \\
\text { ash: scale; metals; } \\
\text { salts }\end{array}$ \\
\hline 2 & 2110 & \begin{tabular}{|l|} 
Aqueous \\
halogenated \\
organic liquids
\end{tabular} & $\begin{array}{l}\text { Aqueous solution with } \\
\text { between } 1 \% \text { and } 99 \% \\
\text { organic liquids }\end{array}$ & Toxicity & $\begin{array}{l}\text { F001. F002. } \\
\text { F005, D004. } \\
\text { D006.D010 }\end{array}$ & $\begin{array}{l}\text { Halogenated and } \\
\text { non-halogenated } \\
\text { organics. }\end{array}$ \\
\hline 3 & 3111 & Ash & $\begin{array}{l}\text { Bottom and fly ash and } \\
\text { residue from } \\
\text { incineration of } \\
\text { radioactive waste }\end{array}$ & Toxicity & $\begin{array}{l}\text { F001-F003 } \\
\text { F005 } \\
\text { D004-D011 }\end{array}$ & $\begin{array}{l}\text { Halogenated and } \\
\text { non-halogenated } \\
\text { solvents; heavy } \\
\text { metals }\end{array}$ \\
\hline 4 & $\begin{array}{l}3113 \\
3114\end{array}$ & $\begin{array}{l}\text { Absorbed } \\
\text { aqueous and } \\
\text { organic liquids }\end{array}$ & $\begin{array}{l}\text { Vermiculite clay or } \\
\text { diatomaceous earth } \\
\text { material contaminated } \\
\text { with aqueous and } \\
\text { organic liquids }\end{array}$ & Toxicity & $\begin{array}{l}\text { F001-F003 } \\
\text { F005 } \\
\text { D004-D005 } \\
\text { D007-D009 } \\
\text { D011 }\end{array}$ & $\begin{array}{l}\text { Halogenated and } \\
\text { non-halogenated } \\
\text { solvents: heavy } \\
\text { metals }\end{array}$ \\
\hline 5 & 3122 & $\begin{array}{l}\text { High organic } \\
\text { content } \\
\text { sludges }\end{array}$ & $\begin{array}{l}\text { Halogenated or non- } \\
\text { halogenated sludges } \\
\text { with }>1 \% \text { organics }\end{array}$ & Toxicity & $\begin{array}{l}\text { F001-F004 } \\
\text { D004-D011 }\end{array}$ & $\begin{array}{l}\text { Halogenated and } \\
\text { non-halogenated } \\
\text { solvents; heavy } \\
\text { metals }\end{array}$ \\
\hline 6 & 3140 & $\begin{array}{l}\text { Cement } \\
\text { sludges, ashes } \\
\text { and solids }\end{array}$ & $\begin{array}{l}\text { Sludges mixed with } \\
\text { solidifying agents such } \\
\text { as cement }\end{array}$ & Toxicity & $\begin{array}{l}\text { F001-F004 } \\
\text { D004-D011 }\end{array}$ & $\begin{array}{l}\text { Halogenated and } \\
\text { non-halogenated } \\
\text { solvents; heavy } \\
\text { metals }\end{array}$ \\
\hline 7 & $\begin{array}{l}3151 \\
3152\end{array}$ & $\begin{array}{l}\text { Chloride, } \\
\text { sulfate and } \\
\text { nitrate salts }\end{array}$ & $\begin{array}{l}\text { Evaporated or process } \\
\text { salts, predominately } \\
\text { nitrate salts }\end{array}$ & Toxicity & D005-D008 & $\begin{array}{l}\text { Chloride, sulfate, } \\
\text { and nitrate salts; } \\
\text { metals }\end{array}$ \\
\hline 8 & 3200 & $\begin{array}{l}\text { Organic matrix } \\
\text { solids }\end{array}$ & $\begin{array}{l}\text { Organic solids which } \\
\text { would leave only } \\
\text { moderate ash residue }\end{array}$ & $\begin{array}{l}\text { Toxicity } \\
\text { Ignitability }\end{array}$ & Not identified & $\begin{array}{l}\text { Activated carbon, } \\
\text { cellulose. organic } \\
\text { resin; metal salts; } \\
\text { trace organics }\end{array}$ \\
\hline 9 & 5400 & $\begin{array}{l}\text { Heterogeneous } \\
\text { debris }\end{array}$ & $\begin{array}{l}\text { Mixtures of metals and } \\
\text { non-metals, } \\
\text { combustibles, soils, } \\
\text { and process residue }\end{array}$ & $\begin{array}{l}\text { Toxicity } \\
\text { Ignitability }\end{array}$ & $\begin{array}{l}\text { F001-F005 } \\
\text { D004-D011 }\end{array}$ & $\begin{array}{l}\text { Halogenated and } \\
\text { non-halogenated } \\
\text { solvents; metals }\end{array}$ \\
\hline 10 & 5440 & $\begin{array}{l}\text { Bulk } \\
\text { combustibles }\end{array}$ & $\begin{array}{l}50 \% \text { to } 95 \% \\
\text { combustibles }\end{array}$ & $\begin{array}{l}\text { Toxicity } \\
\text { Ignitability }\end{array}$ & $\begin{array}{l}\text { F001-F003 } \\
\text { F005 D004 } \\
\text { D006-D011 }\end{array}$ & $\begin{array}{l}\text { Carbon, cellulose, } \\
\text { PVC, rubber, metals, } \\
\text { organics. }\end{array}$ \\
\hline 11 & 6100 & Lab Packs & $\begin{array}{l}\text { Lab chemicals, } \\
\text { packing material }\end{array}$ & $\begin{array}{l}\text { Toxicity } \\
\text { Ignitability } \\
\text { Corrosivity } \\
\text { Reactivity } \\
\end{array}$ & $\begin{array}{l}\text { D001-D008 } \\
\text { D010-D017 }\end{array}$ & $\begin{array}{l}\text { Carbon, } \\
\text { polyethylene } \\
\text { metals, organics. }\end{array}$ \\
\hline 12 & 7200 & Lead Shapes & Bulk lead & Toxicity & Not identified & $\begin{array}{l}\text { d Lead, metals. } \\
\text { organics. }\end{array}$ \\
\hline
\end{tabular}




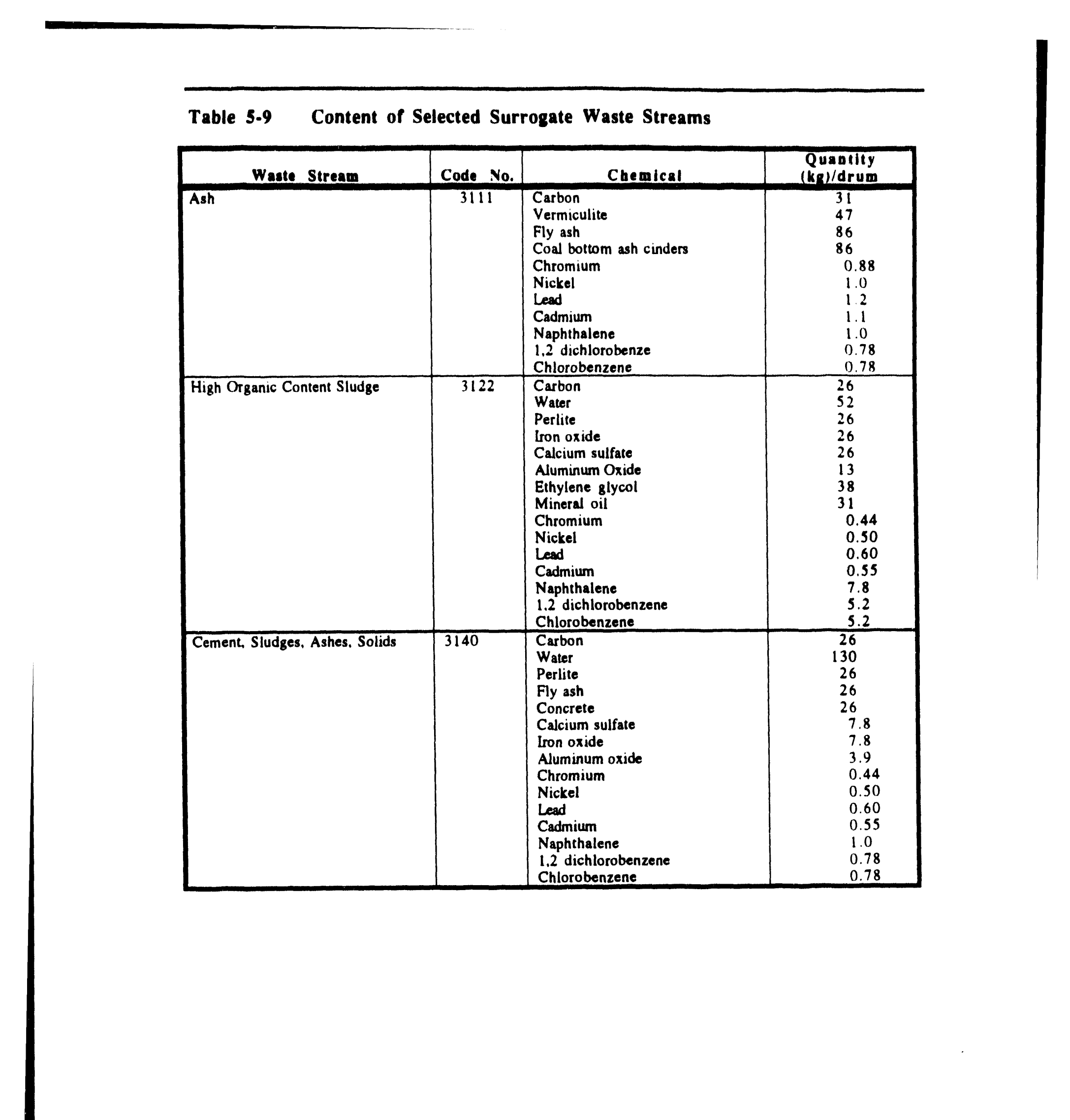


Table 5.9 Hazardous Material Content of Surrogate Waste Streams (Cont.)

\begin{tabular}{|c|c|c|c|}
\hline Waste Stream & $\begin{array}{l}\text { Code } \\
\text { No. }\end{array}$ & Chemical & $\begin{array}{l}\text { Quantity } \\
\text { (kg)/drum }\end{array}$ \\
\hline Heterogeneous Debris & 5400 & $\begin{array}{l}\text { Carbon } \\
\text { Water } \\
\text { Wood } \\
\text { PVC } \\
\text { Neoprene } \\
\text { Mild steel } \\
\text { Glass beads } \\
\text { Concrete } \\
\text { Alumina crucibles } \\
\text { Diatomaceous earth } \\
\text { Chromium } \\
\text { Nickel } \\
\text { Lead } \\
\text { Cadmium } \\
\text { Naphthalene } \\
1,2 \text { dichlorobenzene } \\
\text { Chlorobenzene }\end{array}$ & $\begin{array}{l}13 \\
38 \\
26 \\
26 \\
26 \\
26 \\
26 \\
21 \\
26 \\
26 \\
0.44 \\
0.50 \\
0.60 \\
0.55 \\
1.0 \\
0.78 \\
0.78\end{array}$ \\
\hline
\end{tabular}

- Of the materials listed in the surrogate waste streams. only cresols are considered highly hazardous substances in 40 CFR 355.

constituents associated with these waste streams are provided in Table 5-9. The hazards associated with these are analyzed in Section 5.3.

The calculations of the maximum quantities of each chemical in each waste stream were performed based on an average total weight of each drum of $260 \mathrm{~kg}$ and on the chemical weight percentage from Mayberry et al. (1994). The product of these factors expressed in kilograms, yielded the quantities of the materials and hazardous chemicals in these four waste streams. These quantities of hazardous materials were used to estimate the hazard from wastes being treated by vitrification processes.

The quantities of hazardous byproducts produced by vitrification processes could also be important to the safety of the process. The following are postulated as the primary byproducts of trearment of mixed wastes by vitrification processes as determined from the Pacific Northwest Laboratory (1992), Preliminary Safety Evaluation Document for the Hazardous Waste Treatment Facility, DOE/SR (1993), Richards and Bennett (1990) and SAIC (1993):

- From Organic Contaminants in Wastes

- Carton dioxide $\left(\mathrm{CO}_{2}\right)$

- Water vapor $\left.\left(\mathrm{H}_{2} \mathrm{O}\right)\right)$

- Hydrochloric acid $(\mathrm{HCl})$

- Hydrofluoric acid (HF)

- Hydrobromic acid (HBr) 
- From Inorganic Contaminants in Waste

- Oxides of nitrogen $\left(\mathrm{NO}_{\mathrm{X}}\right)$

- Oxides of sulfur $\left(\mathrm{SO}_{\mathbf{X}}\right)$

- Oxides of cartion $\left(\mathrm{CO}_{\mathrm{x}}\right)$

- Hydrochloric acid $(\mathrm{HCl})$

- Hydrofluoric acid (HF)

- Particulates

- Volatile Metals (Be, Cd, $\mathrm{Hg}$, etc.)

DOE/SR (1993) determined the mass of $\mathrm{NO}_{\mathrm{x}}$ and $\mathrm{SO}_{\mathrm{x}}$ from the processing of 650,000 gallons of mixed waste sludge and found that projected emissions from their vitrification process would result in approximately 27 tons/y of $\mathrm{NO}_{\mathrm{x}}$ and negligible amounts of $\mathrm{SO}_{\mathrm{x}}$. Emission of particulates, metals, and radioactive materials were also estimated as being negligible and controllable using HEPA filtration. The offgas scrubber would be expected to remove any significant quantities of acid. Emissions of $\mathrm{NO}_{\mathrm{x}}$ and an evaluation of possible best available control technologies for the Hanford Waste Vitrification Plant was performed by SAIC (1992) and found to be within EPA limits.

The "Initial Alternative MWTP Flowsheet" memo (Gillins 1993) provides the breakdown. by element, of the different waste categories reported in the Functional and Operation Requirement (F\&OR) documents (Thompson 1992) and the MWTP Process Systems and Facilities Design Study and Cost Estimate for LLNL (Bechtel 1992).

A wide range of hazardous materials are found in mixed waste but most exist only at low concentrations as reflected in Table 5-9. Although some waste streams, such as organic liquids, may have high concentrations of hazardous materials, this waste stream constitutes only $3 \%$ of DOE mixed waste. It is also not credible that many waste streams, such as organic liquids, could be treated by vitrification. The Threshold Quantities, contained in 29 CFR 1910.119, are those amounts of specific hazardous materials which, if they are contained in a process stream, tank, or container, require specific safety procedures, hazard analyses, and emergency action plans under OSHA regulations. The Threshold Planning Quantities, contained in 40 CFR 355, are those amounts of specific hazardous materials which, if they are contained in a facility, require specific emergency plans under EPA regulations. The Threshold Quantities in both regulations typically indicate amounts between 100 and 10,000 pounds as the limit for each of the materials. Of the hazardous materials in Table 5-9 only cadmium, if it is considered to be in oxide form, is on the 40 CFR 355 and 29 CFR 1910.119 highly hazardous material lists.

The Threshold Quantity from 40 CFR 355 for cadmium oxide is 10,000 pounds; the Threshold Quantity of $\mathrm{HCl}$ is 500 pounds; the Threshold Quantity of nitric oxide (considering alt $\mathrm{NO}_{\mathrm{x}}$ as nitric oxide) is 100 pounds; and the Threshold Quantity of $\mathrm{SO}_{\mathrm{x}}$ (considering all $\mathrm{SO}_{\mathrm{x}}$ as sulfur dioxide) is 500 pounds. 
Assuming a maximum inventory of approximately 100 drums of waste and considering the entire inventory of cadmium in those drums, there would be an insufficient quantity to approach the Threshold Quantities for hazardous materials in the wastes. The quantities of gaseous oxides and acids within the system at any one time would also be small compared to the annual emissions referenced above (DOE/SR 1993; SAIC 1992) but have not yet been evaluated for a future mixed low-level waste vitrification unit. Based on this initial inventory screening, a vitrification facility would therefore be considered a low hazard facility as only negligible offsite impact appears possible.

It is noted that, this preliminary assessment should not be considered exhaustive as many different types of hazardous contaminants may be found in mixed wastes considered for treatment by vitrification processes. However, most mixed waste contains hazardous materials as only a small percentage of the total mass of the waste, as reflected in Table 5-9. It is expected that a vitrification facility is not likely, at any time, to contain any significant fraction of a Threshold Quantity of any specific hazardous material.

The quantities of hazardous materials typically found in mixed wastes, as indicated above, indicate that a vitrification facility would present a hazard only to personnel in the facility and would, therefore, be a Low Hazard facility in accordance with the requirements of DOE Order 5481.1B. Should a future vitrification facility treat waste streams with larger quantities of highly hazardous materials, such that considerable hazard to onsite personnel could exist, the facility classification would be Moderate Hazard. Should a future vitrification facility treat waste streams with quantities equal to or in excess of the 29 and 40 CFR Threshold Quantities, the facility could present a hazard to large numbers of on- and offsite personnel and would be considered a High Hazard facility. Facility maximum inventory limits shall be established in facility safety procedures for all hazardous materials brought into the facility to support maintenance of the facility hazard classification eventually selected. The consequences of potential accidents involving the identified hazardous materials are addressed further in Section 5.3.

\subsection{BOUNDING ANALYSES OF POTENTIAL ACCIDENTS}

This hazards analysis characterizes potential hazardous conditions present in a vitrification facility in terms of energy sources, hazardous and radioactive materials, and natural phenomena. A summary of potential hazardous events is presented in Table 5-2 and includes events involving container failure, personnel error, fire, uncontrolled chemical reaction, vehicle accidents, and hazardous and radioactive material releases. Narural phenomena including seismic activity, lightning, rain, and extreme wind, that could affect facility operations, are identified. It is noted that there will be no criticality hazard in a vitrification facility which treats low-level mixed wastes: although some waste contaminated with transuranic isotopes may be treated at the facility, it is 
expected that such waste will be limited. as detailed in Section 5.2, at least to the criteria established in DOE-STD-1027-92 (DOE 1992b), ANSI/ANS-8.15-1981 (ANSI 1981), and ANSI/ANS-8.1 1983 (ANSI 1983).

The hazards inherent in a vitrification facility are assessed in this Section in three broad categories: operational and equipment hazards; radiological hazards; and hazardous material hazards. The potential accident scenarios involve only credible events, as defined in DOE Order 6430.1 A (DOE 1989a), which have an estimated probability of occurrence of $10^{-6}$ or greater. They provide details on the postulated sequence of events, an estimate of the likelihood of the event, and estimates of consequences. Where appropriate, credit is taken for preventive features of the facility design, that is, those controls that keep an event from happening by reducing the event frequency. Passive design features that will remain intact during an accident (for example, building walls) are considered in the accident scenarios. Active design features (for example, building ventilation) are considered in accident scenarios only if they increase the potential accident consequences. No credit is taken for mitigative features, that is, those controls that reduce the consequence level of an event.

Conservative atmospheric transport methods are used to estimate the on- and offsite concentrations of hazardous and radioactive materials following release. Airbome concentrations of radioactive materials were calculated using HOTSPOT (Homann 1991). Airbome concentrations of hazardous materials were calculated using airbome dispersion, $\chi / Q$, values calculated using the method of Hanna et al. (1982). Appendix A contains the calculations from the computer-based model.

In the following analyses, only radioactive and hazardous material releases were identified as having the potential to impact offsite members of the public or the environment. Industrial and operational accidents involving vitrification processes could credibly result in severe injury or death of a worker in the facility, but no potential effects outside the facility were identified other than the potential release of radioactive and hazardous materials. These events could be initiated by a number of credible causes. Therefore, a bounding estimate is performed to verify the hazard classifications which resulted from the examination of inventories. The actual cause of the postulated hazardous and radioactive material release event is not then relevant because more than one credible cause may be postulated.

For the purpose of this hazards analysis, the maximal amounts of radioactive material which could be in storage are determined based on proposed inventory limits. The maximum inventory of radioactive materials are postulated for the facility and the effects of an accident involving these materials are analyzed. The resulting doses to on- and offsite personnel are compared to the dose equivalent criteria in the DOE-STD-1027-92 (DOE 1992b) and DOE Order 
5400.5 (DOE 1990) to verify facility classification for radiological consequences. The maximum inventory of hazardous materials could not be postulated for the facility but the effects of accidents involving the assumed inventory of 100 drums, from Section 5.2, are analyzed. Exposures of onand offsite personnel are assessed with respect to the limits provided by various industrial standards including those of American Conference of Governmental Industrial Hygienists (ACGIH), American Industrial Hygiene Association (AIHA), and National Institute for Occupational Safety and Health (NIOSH) (ACGIH 1990; AIHA 1989; NIOSH 1990).

Accidents are analyzed and maximum source terms are determined in accordance with accepted industry guidance including A Guide to Radiological Accident Considerations for Siting and Design of DOE Nonreactor Nuclear Facilities (Elder et al. 1986), Nuclear Fuel Cycle Facility Accident Analysis Handbook (Ayer et al. 1988), and DOE-STD-1027-92 (DOE 1992b).

Accident effects within the facility are estimated at $30 \mathrm{~m}$ from the source in accordance with the guidance of DOE-STD-1027-92 (DOE 1992b). The exposure of the maximally exposed onsite receptor outside the facility is calculated at $100 \mathrm{~m}$ in accordance with the guidance of DOE-STD1027-92. The exposure to offsite receptors is calculated to the maximally exposed individual at 300 $m$ in accordance with the guidance of DOE-STD-1027-92. In all cases, the meteorological parameters assume "D" class stability, $4.5 \mathrm{~m} / \mathrm{s}$ wind speed, ground level releases, and non-buoyant plumes, in accordance with the Standard recommendation. (The draft DOE Standard DOE-STDSAFT-0019 (DOE 1993e) proposes a method that uses meteorological parameters assuming " $F$ " class stability, and I $\mathrm{m} / \mathrm{s}$ wind speed which is not consistent with the DOE-STD-1027-92 approach and is not used for this analysis as DOE-STD-SAFT-0019 has been issued only in draft.) The accident scenarios assume that site personnel and members of the public will be at the on- and offsite location with the highest airbome concentration of radioactive and hazardous material for the entire accident duration. This assumption provides conservative estimates of the maximum possible exposure of site personnel and members of the public.

\subsubsection{Operational and Equipment Assessment}

This section provides a qualitative analysis of potential vitrification facility operational and equipment accidents to identify those features which are important to safety within the facility. No operational events or equipment failures were identified which could affect personnel outside the facility other than through release of hazardous and radioactive material. Potential accidents involving the release of radioactive and hazardous materials are analyzed in subsections 5.3.2 and 5.3.3. Information on the potential hazards associated with the vitrification are taken from the Savannah River Laboratory (1988), Process Hazards Review 672-T Integrated DWPF Melter Facility, the Pacific Northwest Laboratory (1992), Preliminary Safety Evaluation Document for the Hazardous Waste Treatment Facility, and the draft Defense Waste Processing Facility Safety 
Analysis Report (SRS 1993). The probability estimates of industrial accidents were developed from a database of DOE accidents and industrial safety statistics developed by the National Safety Council (1990) and assume a facility staff of 20 individuals.

\section{Electrical}

The vitrification melters are provided with high voltage, high current power supplies. Various other systems and components are provided with standard electrical power at lower current and voltage. Component failures and personnel errors can result in equipment damage and potential personnel injury or death. As vitrification processes are a new application of an existing technology, the probability and consequences of electrical accidents are not expected to be different from other similar industrial applications. The probability of moderate and high consequence events (severe injury or death or loss of facility operation) is expected to be extremely low ( $10^{-4}$ to $10^{-6}$ ). The probability of low consequence events (minor injury or equipment damage) is expected to be medium to low $\left(10^{-1}\right.$ to $\left.10^{-4}\right)$.

\section{Natural and Compressed Gases}

Natural gas and compressed gases may be used in vitrification processes as a process startup heat source and calibration gases for instrumentation, respectively. All compressed gases are expected to be inert or inert with a small percentage of carbon monoxide, nitric oxide, carton dioxide, or oxygen. Natural and compressed gases used in vitrification processes are considered to pose similar hazards to those from routine industrial gas use. Natural gas could present a fire hazard and an asphyxiation hazard if allowed to accumulate in a confined space by a leak or improper alignment. Compressed gas cylinders also pose a missile hazard if ruptured. All compressed gas use would be performed in compliance with OSHA regulations and Compressed Gas Association standards. The probability of moderate and high consequence events (severe injury or death) is expected to be extremely low $\left(10^{-4}\right.$ to $\left.10^{-6}\right)$. The probability of low consequence events (minor injury or equipment damage) is expected to be moderate to low $\left(10^{-1}\right.$ to $\left.10^{-4}\right)$.

Fire

The potential for fire in a vitrification facility appeared to be low as waste will be contained in approved containers and process systems would be expected to incorporate redundant fire protection features. Fire hazards in a vitrification facility are considered to be lower than fire hazards in other industrial incineration operations. Such a facility will be constructed to DOE 6430.1 A fire protection criteria appropriate to the hazard classification of the facility and to NFPA codes. The systems are constructed of noncombustible materials. The start-up narural gas bumer would be equipped with Underwriters Laboratory and Factory Mutual approved safety systems to prevent the release of uncombusted natural gas. The probability of moderate and high consequence 
events (severe injury or death or facility destruction) is expected to be extremely low $\left(10^{-4}\right.$ to $\left.10^{-6}\right)$. The probability of low consequence events (minor injury or equipment damage) is expected to be low $\left(10^{-2}\right.$ to $\left.10^{-4}\right)$.

\section{Spills of Glass}

The potential for a failure of the melt chamber or spill during glass removal is credible. Glass is drained from the melt chamber via a weir or tap and mechanical failures could result in a spill. It is expected that such a spill would be contained by a secondary containment surrounding the system. The walls or bottom of the melt chamber could also fail due to corrosion of metal walls or bum-through of the refractory liner by a broken rod electrode. The waste/glass melt environment has been demonstrated to be extremely corrosive and the probability of failure of metal electrodes is high. Industrial accidents in large glass melters have occurred due to bum-through of vessel walls from broken rod electrodes (Peters 1994) and resulted in the release of the glass inventory to the process area and subsequent facility fire. A future vitrification facility should consider installation of a secondary containment surrounding the entire vitrification system sufficient to contain the entire glass melt inventory. The consequences of a major glass spill and subsequent facility fire are limited by the consequences of the fire analyzed in 5.3.2 and 5.3.3.

The probability of moderate and high consequence events (severe injury or death or facility destruction is expected to be low $\left(10^{-2}\right.$ to $\left.10^{-4}\right)$. The probability of low consequence events (minor injury or equipment damage) is expected to be moderate to high $\left(>10^{-1}\right.$ to $\left.10^{-2}\right)$.

\section{Explosion}

The potential for explosion in the vitrification systems is credible due to the wide range of chemicals that may be present in the waste and the water used to cool the systems. Explosions could occur in the melter feed tank, the primary process vessel, the offgas system. or any secondary combustion chamber due to the accumulation of explosive gas mixtures. Steam explosions in the glass melter are also credible in the event of the introduction of water into the process vessel if there is a salt layer on top of the melt. The potential for such an event is reduced by the inherent operational mode of the vitrification systems at reduced pressure and in a predominantly inert atmosphere. The potential for explosion in the facility appeared to be low as waste will be contained in DOT specification containers and the natural gas portion of the process system would incorporate explosion prevention features. Explosion hazards in a vitrification facility are considered to pose lesser hazards than those from other industrial incineration operations. Such a facility will be constructed to DOE 6430.1 A criteria appropriate to the hazand classification of the facility. Explosion relief features may be incorporated into vitrification systems. The probability of moderate and high consequence events (severe injury or death or 
facility destruction) is expected to be extremely low $\left(10^{-4}\right.$ to $\left.10^{-6}\right)$. The probability of low consequence events (minor injury or equipment damage) is expected to be low $\left(10^{-2}\right.$ to $\left.10^{-4}\right)$.

\section{Industrial Safety Hazards}

The potential for routine industrial hazards, (such as bum, trip, fall, lifting, and rotating equipment hazards) appeared to be comparable to or lower than other similar industrial facilities. Vitrification facilities are mechanically simple processes with few moving parts. Motor driven mechanisms would be enclosed or guarded to meet OSHA regulations. The probability of moderate and high corisequence events (severe injury or death) is expected to be low $\left(10^{-2}\right.$ to $\left.10^{-4}\right)$. The probability of low consequence events (minor injury or equipment damage) is expected to be high(> $\left.10^{-1}\right)$.

\section{Hazardous Chemical and Radiation Exposure}

A vitrification facility will contain radioactive and hazardous material at low concentrations on otherwise inert material in waste which is packaged in DOT specification containers. Therefore, direct contact of workers with these hazardous and radioactive constituents will be infrequent. The possibility of spills will be present and appropriate spill response procedures will be necessary. Worker radiation exposures will be controlled in accordance with 10 CFR 835 (DOE 1994) regulations and minimized in accordance with DOE "as low as reasonably achievable" (ALARA) policy. Worker hazardous chemical exposures will be ccintrolled in accordance with DOE Order 5480.10 (DOE 1985) requirements. The probability of moderate and high consequence events (severe injury or death) is expected to be extremely low $\left(10^{-4}\right.$ to $\left.10^{-6}\right)$. The probability of low consequence events (minor unplanned exposures) is expected to be high $\left(>10^{-1}\right)$.

\subsubsection{Radiological_Assessment}

The radiological assessment calculates doses to the maximally exposed individuals in terms of 50-y, whole body, committed effective dose equivalent (CEDE). CEDEs are determined in accordance with the International Commission on Radiological Protection (ICRP) Publication 30 methodology (ICRP 1979) and DOE Orders 5400.5 (DOE 1990) and 5480.11 (DOE 1989b).

Calculated CEDEs are not reflective of those which would actually be received by an individual during an accident, but are conservative estimates of the dose to a worker and to a member of the general public under accident conditions. These estimates are used to verify facility hazard classification. The duration of exposure is assumed to be equal to the duration of the release. (The actual duration of any worst-case accident is, therefore, not relevant to the dose calculation as the source term will be directly proportional to the receptor intake which is in tum directly proportional to the CEDE.) 
Sealed radioactive sources and check sources may be used in a vitrification facility. Sealed sources and check sources are constructed and distributed in accordance with USNRC requirements in 10 CFR 30 through 34 (NRC 1993) and ANSI standards (ANSI 1977) to pose minimal hazards. Specifically licensed sealed sources are constructed to withstand accident environments. The analyses of this section assume any significant sealed source will withstand accident conditions and they are excluded from the inventory of material at risk in accordance with DOE-STD-1027-92 guidance.

The on- and offsite CEDEs were calculated at $30 \mathrm{~m}, 100 \mathrm{~m}$, and $300 \mathrm{~m}$. Representative and limiting isotopes are chosen for the dose calculations as representative of those which are found in mixed wastes. The limits specified in DOE-STD-1027-92 (DOE 1992b) are an onsite CEDE of 1 rem (or more) at $100 \mathrm{~m}$ as the Category 2 criterion and 10 rem (or more) at $30 \mathrm{~m}$ over a 24 hour period as the Category 3 criteria.

Any number of accidents are possible in a vitrification facility and will result in a range of consequences: spills of containers of waste, leaks from treatment systems, fires involving limited quantities of combustible waste, leaks from the process systems, and small explosions which would be contained by the building structure. In order to envelope the consequences of all the possible scenarios, a generalized release of radioactive material is postulated to occur within the building. This worst-case accident for a vitrification facility could be a fire or explosion which is assumed to involve the maximum building inventory of radioactive material. The potentially contaminated effluent from the event leaks from the building through a door, the ventilation system. or an opening in the building side or roof and is released to the environment.

The material-at-risk is defined by the facility inventory as detailed in subsection 5.2, above. The release fractions are as recommended in DOE-STD-1027-92 (DOE 1992b). No credit is taken for plume rise, although some of the accidents could result in a buoyant release, which would reduce the resultant on- and offsite CEDEs. The results from the computer-based HOTSPOT model (Homann 1991) are provided in Appendix A. The maximum potential onsite CEDE are presented in Tables 5-10 and 5-11. 
Table 5-10. Radioactive Material Category 3 Release Factors, Source Terms, and Doses

\begin{tabular}{|c|c|c|c|c|c|}
\hline Nuclide & $\begin{array}{l}\text { Release } \\
\text { Fraction }\end{array}$ & $\begin{array}{l}\text { Source } \\
\text { Term (Ci) }\end{array}$ & $\begin{array}{l}\text { Dose at } \\
30 m \text { (rem) }\end{array}$ & $\begin{array}{c}\text { Dose at } \\
100 \mathrm{~m} \text { (rem) }\end{array}$ & $\begin{array}{c}\text { Dose at } \\
300 \mathrm{~m} \text { (rem) }\end{array}$ \\
\hline Tritium $\left({ }^{3} \mathrm{H}\right)$ & 1.0 & 100 & 0.04 & 0.0047 & 0.00059 \\
\hline${ }^{14} \mathrm{C}$ & 0.01 & 0.04 & 0.00036 & 0.000042 & 0.0000052 \\
\hline $\begin{array}{l}\text { Activation Products } \\
\left({ }^{60} \mathrm{Co}\right)\end{array}$ & 0.001 & 0.028 & 0.0089 & 0.0021 & 0.00013 \\
\hline $\begin{array}{l}\text { Fission Products } \\
\left({ }^{90} \mathrm{Sr} / \mathrm{Y}\right)\end{array}$ & 0.001 & 0.0016 & 0.018 & 0.001 & 0.00026 \\
\hline Iodines $(125 \mathrm{I})$ & 0.5 & 0.025 & 0.0026 & 0.0003 & 0.000037 \\
\hline Thorium (232 Th) & 0.001 & 0.00001 & 0.047 & 0.0054 & 0.00068 \\
\hline Uranium $(238 U)$ & 0.001 & 0.0004 & 0.2 & 0.024 & 0.003 \\
\hline Transuranics $\left({ }^{239} \mathrm{Pu}\right)$ & 0.001 & 0.00005 & 0.07 & 0.0082 & 0.001 \\
\hline Total & & & 0.39 & 0.046 & 0.0056 \\
\hline
\end{tabular}

Table 5-11. Radioactive Material Category 2 Release Factors, Source Terms, and Doses

\begin{tabular}{|c|c|c|c|c|c|}
\hline Nuclide & $\begin{array}{l}\text { Release } \\
\text { Fraction }\end{array}$ & $\begin{array}{c}\text { Source } \\
\text { Term } \\
\text { (Ci) }\end{array}$ & $\begin{array}{l}\text { Dose at } \\
30 \mathrm{~m} \text { (rem) }\end{array}$ & $\begin{array}{l}\text { Dose at } \\
100 \mathrm{~m} \\
\text { (rem) }\end{array}$ & $\begin{array}{l}\text { Dose at } \\
300 \mathrm{~m} \text { (rem) }\end{array}$ \\
\hline Tritium $\left({ }^{3} \mathrm{H}\right)$ & 1.0 & 30.000 & 12 & 1.4 & 0.18 \\
\hline${ }^{14} \mathrm{C}$ & 0.01 & 140 & 1.3 & 0.15 & 0.018 \\
\hline $\begin{array}{l}\text { Activation Products } \\
\left({ }^{60} \mathrm{Co}\right)\end{array}$ & 0.001 & 19 & 12 & 1.4 & 0.18 \\
\hline $\begin{array}{l}\text { Fission Products } \\
\left({ }^{90} \mathrm{Sr} / \mathrm{Y}\right)\end{array}$ & 0.001 & 2.2 & 12 & 1.4 & 0.018 \\
\hline lodines $(125 \mathrm{D}$ & 0.5 & 130 & 12 & 1.5 & 0.18 \\
\hline Thorium $(232 \mathrm{Th})$ & 0.001 & 0.0018 & 8.4 & 0.98 & 0.12 \\
\hline Uranium $(238 \mathrm{U})$ & 0.001 & 0.024 & 12 & 1.4 & 0.18 \\
\hline Transuranics $\left({ }^{239} \mathrm{Pu}\right)$ & 0.001 & 0.0056 & 7.9 & 0.91 & 0.11 \\
\hline Total & & & 78 & 9.1 & 0.99 \\
\hline
\end{tabular}

\subsubsection{Hazardous Material Assessment}

The hazardous material accident scenarios calculate exposures to onsite personnel and members of the public. Calculated airbome concentrations of hazardous materials are not reflective of those which would actually be experienced by an individual during an accident, but are conservative estimates of the theoretical maximum exposures of a worker and of a member of the general public. These estimates are used to verify facility hazard classification.

The onsite aibome concentrations of hazardous materials were calculated at $30 \mathrm{~m}$ and 100 $\mathrm{m}$ and the off-site concentrations were calculated at $300 \mathrm{~m}$. These maximum aibome concentrations were then compared to the various industrial and governmental standards provided by OSHA, EPA, AIHA, ACGIH, and NIOSH. The OSHA, ACGIH, and NIOSH set standards for controlling exposures of worker to hazardous materials, thus these standards are not directly 
applicable to exposures of members of the public. The AIHA sets standards for public exposures called Emergency Respunse Planning Guides (ERPGs). Very few ERPG concentration values have been set by AIHA, thus these are of only limited utility. The currently identified highly hazardous materials from 29 CFR 1910.119 and 40 CFR 355 together with the more numerous AIHA, ACGIH, and NIOSH standards are provided for reference in tabular form in Appendix B. The definitions of industrial hygiene and emergency preparedness terms from AIHA, ACGIH. NIOSH. and OSHA standards are contained in Appendix C.

The unique hazardous materials that may be part of the mixed waste streams treated by a vitrification facility cannot be defined at this time. Surrogate materials for a few waste streams for the demonstration of vitrification processes are catalogued in Section 5.2. These materials are considered representative and are used to assess consequences of accidents involving stored waste. As noted previously, hazardous materials are typically minor contaminants in mixed waste streams, such that this approach is considered representative. The process by-products, detailed in Section 5.2. are used to assess the consequences from these sources.

The conclusion from subsection 5.2 is verified by summing the total inventory of hazardous materials in 100 mixed waste drums and the maximum quantities of process by-products resulting from a weeks activity of a vitrification facility, applying appropriate release and dispersion factors (Elder et al. 1986; Ayer 1988), and calculating the resultant on- and offsite airbome concentrations by application of the appropriate $\chi / Q$ values, $0.017 \mathrm{~s} / \mathrm{m}^{3}$ at $30 \mathrm{~m}, 0.0016 \mathrm{~s} / \mathrm{m}^{3}$ at $100 \mathrm{~m}$, and $0.0002 \mathrm{~s} / \mathrm{m}^{3}$ at $300 \mathrm{~m}$.

The hazardous by-products of vitrification $\left(\mathrm{NO}_{x}, \mathrm{SO}_{x}\right.$, and $\mathrm{HCl}$ ) are subject to leakage due to equipment failure, leakage due to personnel error, and damage to the system and release of the material due to fires, uncontrolled chemical reactions, vehicular accidents, and falls of heavy objects.

To bound the possible consequences of accidents involving mixed waste containers, a fire involving the entire 100 drum waste inventory was postulated. The fire is assumed to bum for 1 hour and to consume the entire waste inventory. A release fraction of 0.01 is applied to all metals and a release fraction of 0.001 is applied to all combustible organics.

During normal operation, the vitrification unit converts the hazardous organic constituents of mixed waste to carbon dioxide and water, thus reducing their hazardous potential. Metals and inert materials are converted to slag and remain in the process vessel. Some volatile metals are carried over into the secondary chamber, are oxidized upon contact with air, condensed in the quench, and are removed from the off-gas stream in the filter system. Halogens are converted to their complementary acid and neutralized and removed by the scrubber. Leaks or equipment 
failures in the process systems could release acids, gases, molten glass, or particulate metal oxides into the facility, but no significant release mechanism from the facility could be identified. Thus, no accidents were identified which could increase the release fractions of hazandous materials over those used in the analysis. Spills of mixed waste are possible, but would have consequences only within the facility and would pose lesser hazards to personnel outside the facility than those analyzed.

No plume rise is postulated in the scenarios although releases of heated gas or vapor and fires would result in significant plume rise and lower down-wind concentrations. If plume rise was taken into account. the on- and offsite consequences would be less than those estimated.

The results of the waste fire scenario are presented in Table 5-12. All aibome concentrations of hazardous materials were less than their respective industrial and govemmental standards provided by OSHA, EPA, AIHA, ACGIH, and NIOSH.

Table 5-12. Waste Fire Accident Results

\begin{tabular}{|c|c|c|c|c|c|c|c|}
\hline Material & $\begin{array}{c}\text { A mount } \\
(k g)\end{array}$ & $\begin{array}{l}\text { Release } \\
\text { Fraction }\end{array}$ & $\begin{array}{c}\text { Source } \\
\text { Term } \\
(\mathrm{g})\end{array}$ & $\begin{array}{c}\text { Concentration } \\
\text { in } \mathrm{mg} / \mathrm{m}^{3} \text { at } \\
30 \mathrm{~m}\end{array}$ & $\begin{array}{l}\text { Concentration } \\
\text { in } \mathrm{mg} / \mathrm{m}^{3} \text { at } \\
100 \mathrm{~m}\end{array}$ & $\begin{array}{l}\text { Concentration } \\
\text { In } \mathrm{mg} / \mathrm{m}^{3} \text { at } \\
300 \mathrm{~m}\end{array}$ & $\begin{array}{c}\text { Standard } \\
m / m^{3}\end{array}$ \\
\hline Chromium & 55 & 0.01 & 550 & 2.6 & 0.24 & 0.030 & $\begin{array}{l}500 \text { (DLH) } \\
0.5(\mathrm{TLV})\end{array}$ \\
\hline Nickel & 63 & 0.01 & 630 & 3.0 & 0.28 & 0.035 & $\begin{array}{l}0.05 \text { (TLV) } \\
50 \text { (LOC) }\end{array}$ \\
\hline Lead & 75 & 0.01 & 750 & 3.5 & 0.33 & 0.042 & 0.05 (PEL) \\
\hline Cadmium & 69 & 0.01 & 690 & 3.3 & 0.31 & 0.038 & $\begin{array}{l}0.05 \text { (TLV) } \\
40 \text { (IDLH) } \\
4 \text { (LOC) }\end{array}$ \\
\hline Naphthalene & 270 & 0.001 & 270 & 1.3 & 0.12 & 0.015 & $50(T L V)$ \\
\hline $\begin{array}{l}1.2 \text { dichloro } \\
\text { benzene }\end{array}$ & 190 & 0.001 & 190 & 0.90 & 0.084 & 0.011 & 301 (TLV.C) \\
\hline chlorobenzene & 190 & 0.001 & 190 & 0.90 & 0.084 & 0.011 & $46(T L V)$ \\
\hline
\end{tabular}

\subsection{CONSEQUENCE ANALYSIS AND PRELIMINARY HAZARD CLASSIFICATION}

The consequences of the accident scenarios compare hypothetical exposures and effects to DOE requirements (DOE 1992b) and accepted industry standards (ACGIH, 1990; AIHA, 1989; NIOSH 1990). Qualitative estimates of the probability of accidents and their maximum expected consequences are provided. The probability estimates are based on engineering judgment and industrial data. In addition, the design bases specified in UCRL-15910 (Kennedy et al. 1990) for external phenomena such as earthquakes, extreme winds, and rain are considered in determining the probability of such events. The probability and consequence of each event are evaluated to establish hazard-specific probability and consequence levels. 


\subsubsection{Consequences of Radiological Assessments}

For an Exempt facility, the maximum potential onsite CEDEs will be less than the Category 3 values calculated in Section 5.3. These are the following: $0.39 \mathrm{rem}$ at $30 \mathrm{~m}, 46 \mathrm{mrem}$ at $100 \mathrm{~m}$. and $5.6 \mathrm{mrem}$ at $300 \mathrm{~m}$. The doses associated with a vitrification facility operated as Category 3 would be between these values and the Category 2 threshold values calculated in Section 5.3. These are the following: up to $78 \mathrm{rem}$ at $30 \mathrm{~m}, 9.1 \mathrm{rem}$ at $100 \mathrm{~m}$, and $0.99 \mathrm{rem}$ at $300 \mathrm{~m}$. The onsite dose equivalent at $30 \mathrm{~m}$ would be more than the DOE standard of $10 \mathrm{rem}$ for a Category 3 facility so that mitigative measures would be indicated to reduce the exposure or to limit the inventory if the facility were to be operated as Category 3. The onsite dose equivalent at $100 \mathrm{~m}$ is more than the DOE standard of 1 rem for a Category 2 facility. No DOE offsite accidental dose standards exist. however, the offsite dose is minimal in comparison to current NRC offsite accidental dose standards (NRC 1993).

\subsubsection{Consequences of Hazardous Material Assessments}

The results of the Section 5.3 accident analyses indicate that maximal releases of hazardous materials from stored waste and the process systems could have impacts only onsite. Although onsite concentrations at 30 and $100 \mathrm{~m}$ for chromium, nickel, lead, and cadmium could exceed continuous occupational exposure limits (TLVs and PELs); no significant health effects would be expected from these exposures. Existing short-term hazard limits (IDLHs and LOCs) would not be exceeded either on- or offsite. No significant effects were identified to offsite members of the public or the environment.

\subsubsection{Conclusions}

The radiological assessments indicate that a vitrification facility may be an Exempt (nonnuclear), a Category 3, or a Category 2 facility based on the maximum inventory of radioactive material selected. It will have minimal impacts to offsite personnel and the environment in all cases. The calculated impacts would result in no significant injury or risk of illness and only minor impact to the environment. The probability of occurrence of the worst-case accidents are estimated to be low $\left(10^{-2}\right.$ to $\left.10^{-4} / y\right)$.

The hazardous materials assessment indicates that a vitrification facility would be low hazard with respect to hazardous materials. It would have minimal impacts to offsite personnel and the environment. The probability of occurrence of the worst-case accident is estimated to be low $\left(10^{-2}\right.$ to $\left.10^{-4} / y\right)$. 


\subsection{REFERENCES}

American Conference of Governmental Industrial Hygienist (1990), Threshold Limit Values and Biological Exposure Indices for 1990-1991, American Conference of Govemmental Industrial Hygienists, Cincinnati, $\mathrm{OH}$.

American Industrial Hygiene Association (1989), Emergency Response Planning Guidelines. American Industrial Hygiene Association. Akron, $\mathrm{OH}$.

American National Standards Institute (1977), Sealed Radioactive Sources, Classification, American National Standards Institute, Inc., ANSI N542-1977.

American National Standards Institute (1981), American National Standard for Nuclear Criticality Control of Special Actinide Elements. American Nuclear Society, Standards Committee Work Group ANS-8.15, ANSI/ANS-8.15-1981.

American National Standards Institute (1983), Nuclear Criticality Safety in Operations with Fissionable Materials Outside Reactors, American Nuclear Society, Subcommittee ANS-8, ANSI/ANS-8.1-1983.

Ayer, J.E., A.T. Clark, P. Loysen, M.Y. Ballinger, J. Mishima, W.C. Zarskj, W.S. Gregory, and B.D. Nichols (1988), Nuclear Fuel Cycle Facility Accident Anatysis Handbook, U.S. Nuclear Regulatory Commission, Washington, D.C., NUREG-1320.

Bechtel Corporation (1992), Mixed Waste Treatment Project Process Systems and Facilities: Design Study and Cost Estimates for LLNL, September, 1992.

Coats, D.W., and Murray, R.C., (1984), Natural Phenomena Hazards Modeling Project: Seismic Hazard Models for Department of Energy Sites, Lawrence Livermore National Laboratory, Livermore, CA, UCRL-53582, Rev. 1, November 1984.

Coats, D.W., and Murray, R.C., (1985), Natural Phenomena Hazards Modeling Project: Extreme Wind/Tornado Hazard Models for Department of Energy Sites. Lawrence Livermore National Laboratory, Livermore, CA, UCRL-53526, Rev. 1, August 1985.

Dalton D. (1992), SAIC-Idaho Falls, Waste Management Technology Division, personal communication with M. Aycock, SAIC-Pleasanton, Regulatory Compliance and Technical Services Division, facsimile transmittal dated May 21, 1992, intemal SAIC document.

Department of Energy (1985), Contractor Industrial Hygiene Program, DOE. Washington, D.C., DOE 5480.10.

Department of Energy (1986), Safety Analysis and Review System, DOE, Washington, D.C., DOE 5481.1B.

Department of Energy (1988a), Environmental Survey Preliminary Report, Stanford Linear Accelerator Laboratory, DOE, Washington, D.C., DOE/EH/OEV-38-P.

Department of Energy (1988b), Radioactive Waste Management, DOE, Washington, D.C., DOE 5820.2A.

Department of Energy (1988c), External Dose Conversion Factors for Calculation of Dose to the Public, DOE, Washington, D.C., DOE/EH-0070.

Department of Energy (1988d), Internal Dose Conversion Factors for Calculations of Dose to the Public, DOE, Washington, D.C., DOE/EH-0071. 
Department of Energy (1989a), General Design Criteria, DOE. Washington. D.C.. DOE Order 6430.1A.

Department of Energy (1989b), Radiation Protection for Occupational Workers, DOE. Washington. D.C., DOE 5480.11 Change 1.

Department of Energy (1990), Radiation Protection of the Public and the Environment, DOE, Washington, D.C., DOE 5400.5.

Department of Energy (1991b), Guidelines for the Preparation of Safety Anatysis Reports for DOE Nuclear Facilities and Nonfacility Nuclear Operations, DOE. Washington, D.C.. SG 830.110, July 1991. DRAFT

Department of Energy (1991c), Environmental Restoration and Waste Management Five-Year Plan. DOE, Washington, D.C., FYP DOE/S-0089P.

Department of Energy (1991d), Unreviewed Safety Questions, DOE. Washington. D.C.. DOE Order 5480.21 .

Department of Energy (1992a), Nuclear Safety Analysis Reports, DOE, Washington, D.C., DOE Order 5480.23.

Department of Energy (1992b), DOE Standard - Hazard Categorization and Accident Analysis Techniques for Compliance with DOE Order 5480.23. Nuclear Safety Analysis Reports, DOE, Washington, D.C., DOE-STD-1027-92.

Department of Energy (1992c), Technical Safety Requirements, DOE, Washington, D.C., DOE Order 5480.22 .

Department of Energy (1992d), DOE Standard - Natural Phenomena Hazards Performance Categorization Criteria for Structures, Systems and Components, DOE, Washington. D.C., DOE-STD-1021-92.

Deparment of Energy (1992e), DOE Standard - Guidelines for Use of Probabilistic Seismic Hazard Curves at Department of Energy Sites, DOE, Washington, D.C., DOE-STD-1024-92, December.

Department of Energy (1993a), Title 10, "Nuclear Safety Management," Code of Federal Regulations: Energy, DOE, Washington, D.C., proposed rule, 10 CFR 830.

Department of Energy (1993b), Natural Phenomena Hazards Mitigation, Washington, D.C., DOE Order 5480.28.

Department of Energy (1993c), DOE Standard - Natural Phenomena Hazards Site Characterization Criteria, DOE, Washington, D.C., DOE-STD-1022-92, April 1993 DRAFT.

Department of Energy (1993d), DOE Standard - Natural Phenomena Hazards Assessment Criteria, DOE, Washington, D.C.. DOE-STD-1023-92, April 1993 DRAFT.

Deparment of Energy (1993e), Guidance for Preparation of DOE 5480.22 (TSR) and DOE 5480.23 (SAR) Implementation Plans, DOE, Washington D.C., DOE Standard DOE-STDSAFT-0019, DRAFT.

Department of Energy (1993f), Natural Phenomena Hazards Design and Evaluation Criteria for Department of Energy Facilities, DOE, Washington D.C., DOE Standard DOE-STD-102092, DRAFT.

Department of Energy (1994), Radiation Protection for Occupational Workers, DOE. Washington D.C., 10 CFR 835. 
Department of Energy, Savannah River Operations Office (1993), Draft Environumental Assessment - Treatment of M-Area Mixed Wastes at the Savannah River Site. Aiken. SC. October 1993.

Department of Labor (1993), Labor, Title 29 Code of Federal Regulations, Washington, D.C.

Elder, J.C., J.M. Graf, J.M. Dewart, T.E. Buhl, W.J. Wenzel, L.J. Walker, and A.K. Stoker (1986), A Guide to Radiological Accident Considerations for Siting and Design of DOE Nonreactor Nuclear Facilities, Los Alamos National Laboratory, Los Alamos, New Mexico, UC-41, LA-10294-MS.

Environmental Protection Agency (1993), Protection of Environment, Title 40, Code of Federal Regulations, Washington D.C.

Environmental Protection Agency, Federal Emergency Management Agency, and Department of Transportation, (1987),Technical Guidance for Hazards Analyses, Emergency Planning for External Hazardous Substances, EPA, Washington, D.C.

Frahm, A.M., F.A. Morris, and G.H. McCabe (1992), Regulatory Requirements for Deploying Integrated Demonstration Technologies, Battelle Seattle Research Center, BHARC$800 / 92 / 005$.

Gillins, R. (1993), Memorandum: From: R. Gillins, SAIC Idaho Falls; To: Distribution, Initial Alternative MWTP Flow Sheet, April 2, 1993.

Hallinan, E. (1988), "Supplement 6.06, Safety Analysis Guide," Lawrence Livermore National Laboratory, Health and Safety Manual, Livermore, CA.

Hanna, S.R., Briggs, G.A., and Hosker, R.P., (1982), Handbook of Atmospheric Diffusion, Technical Information Center, USDOE, DOE/TIC-1 1223 (DE82002045).

Homann. S. (1991), HOTSPOT Health Physics Code, Homann Associates, Inc., Fremont, CA.

Intemational Commission on Radiological Protection (1979), Limits for Intakes of Radionuclides by Workers, ICRP Publication 30, New York, NY.

Kennedy, R.P., S.A. Short, J.R. McDonald, M.W. McCann, R.C. Murray, and J.R. Hill (1990), Design and Evaluation Guidelines for Department of Energy Facilities Subjected to Natural Phenomena Hazards, Lawrence Livermore National Laboratory, Livermore, CA, UCRL15910.

Mayberry, J. (1993), Memorandum: "Waste Stream Definition," From: John Mayberry; To: Distribution, February 5, 1993.

Mayberry, J. ; Frazier, G.; Bostick, W.; Hoffman, D.; Chiang, J.; Hermes, W.; Gibson, L.; and Richmond, A. (1994), Surrogate Formulations for Thermal Treatment of Low-Level Mixed Waste, Part II: Selected Mixed Waste Treatment Project Waste Streams, DOE/MWIP-16.

Musgrave, B. (1993), SAIC Contact Report: Peter Yimbo, SAIC Pleasanton; With: Burdon Musgrave, LLNL, April 14, 1993.

National Institute for Occupational Safety and Health (1990), NIOSH Pocket Guide to Chemical Hazards, NIOSH, Department of Health and Human Services, Cincinnati, OH.

National Safety Council (1990), Accident Facts, Chicago, IL.

Nuclear Regulatory Commission (1993), Energy, Title 10, Code of Federal Regulations, Washington, D.C. 
Pacific Northwest Laboratory (1992), Preliminary Safety Evaluation Document for the Hazardous Waste Treatment Facility, Battelle, Richland, IVA, May 6, 1992, Draft.

Peters, R. (1994), "Review Comments on Preliminary Hazards Analysis for Vitrification Processes," Battelle Pacific Northwest Laboratory, memorandum dated 16 March 1994, to J. Russell, SAIC.

Richards, R.S., and Bickford. D.F.. (1990), Small High-Speed Glass Melter for Waste Vitrification, Proceedings of the American Ceramic Society meeting of April 23, 1990, Dallas, TX, paper \#3-JXIV-90.

Richards, R.S., and Bennett, G.F.. (1990), Vitrification of Municipal Solid Waste Combustor Ash. Proceedings of the First US Conference on Municipal Solid Waste Management. June 13-16, 1990.

Savannah River Laboratory (1988), Process Hazards Review 672-T Integrated DWPF Melter Facility, Technical Division. DPSTPH-672-T-2, September 1988.

Savannah River Site (1993), Draft Defense Waste Processing Facility Safety Analysis Report, Westinghouse Savannah River Company. DPSTSA-200-10, Sup. 20, Rev. 10, September 1993.

Savy, J., and R. Murray (1988), Natural Phenomena Modeling Project: Flood Hazard Models for Department of Energy Sites, Lawrence Livermore National Laboratory, Livermore, CA, UCRL-53851.

Science Applications Intemational Corporation (1992), As Evaluation of Potentially Applicable Control Technologies for Nitrogen Oxide Emissions from the Hanford Waste Vitrification Project, prepared for the Westinghouse Hanford Corporation by the SAIC Advanced Energy Technologies Division, Los Altos, CA, January 1992.

Science Applications International Corporation (1993), personal communication of J. Russell, SAIC with R. Richards, Glasstech, Inc., October 7, 1993, internal SAIC document.

Thompson, T.K. (1992), Mixed Waste Treatment Project: Functional and Operational Requirements for an Integrated Facility. 


\section{APPENDIX A}

\section{HOTSPOT CALCULATIONS}




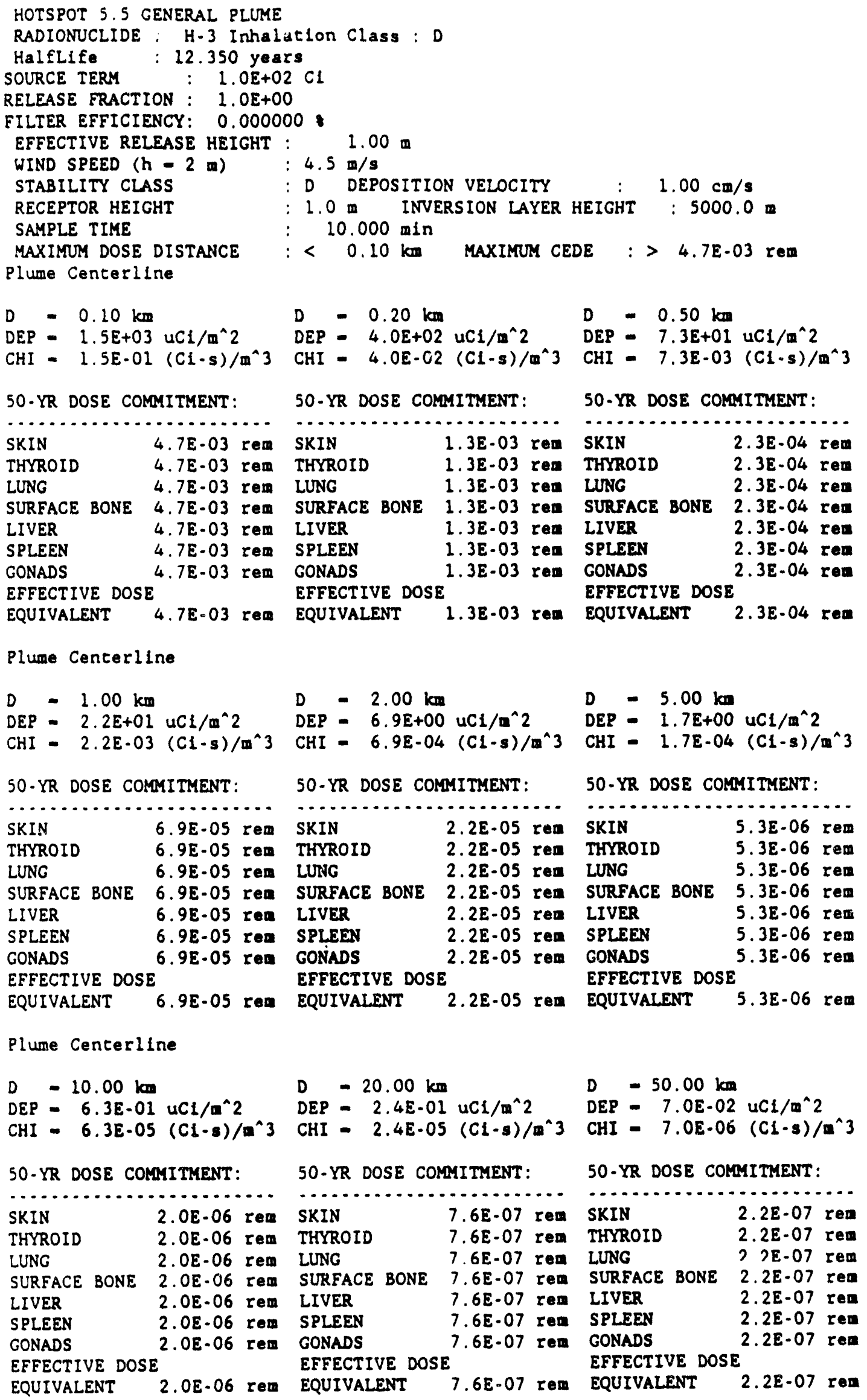




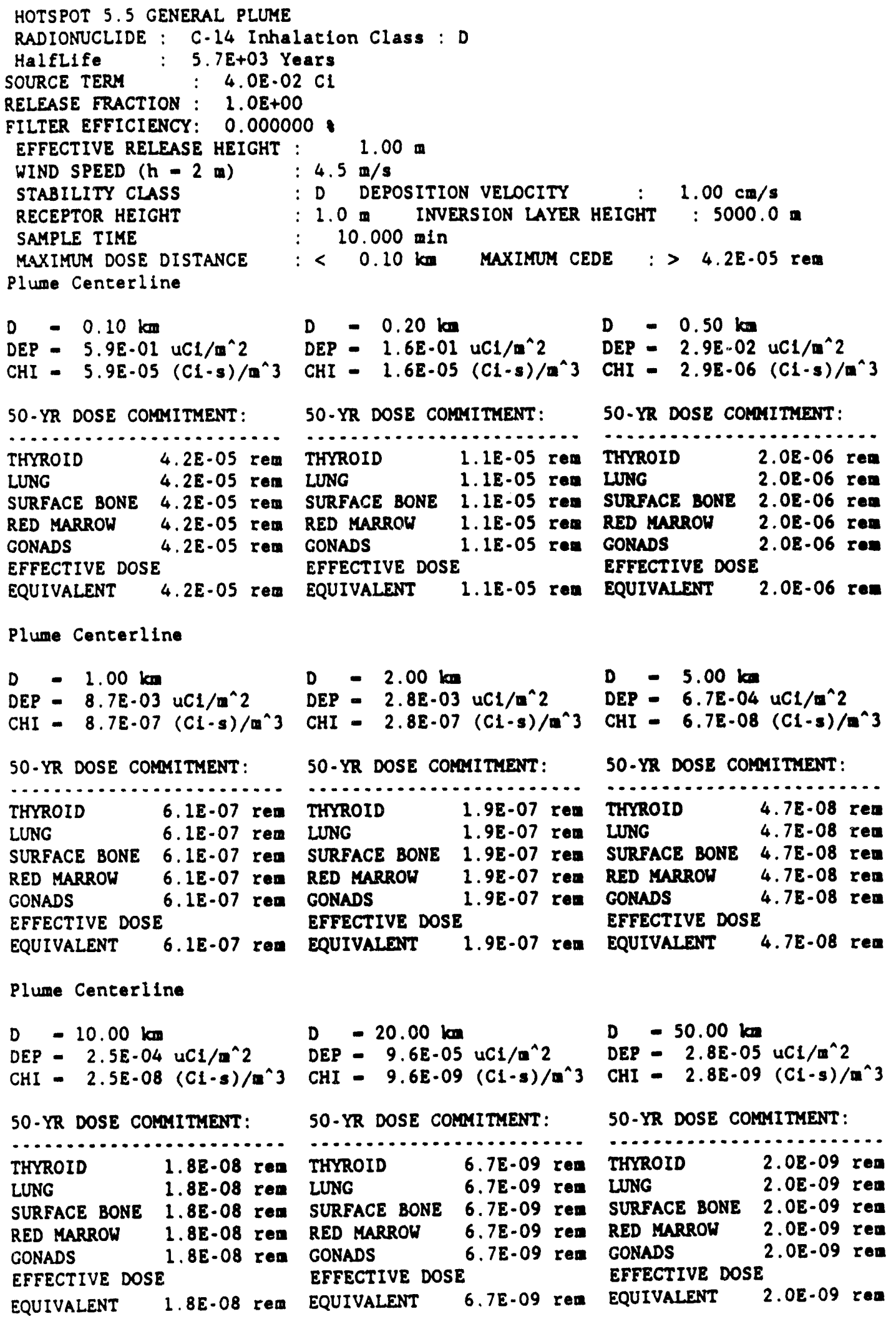




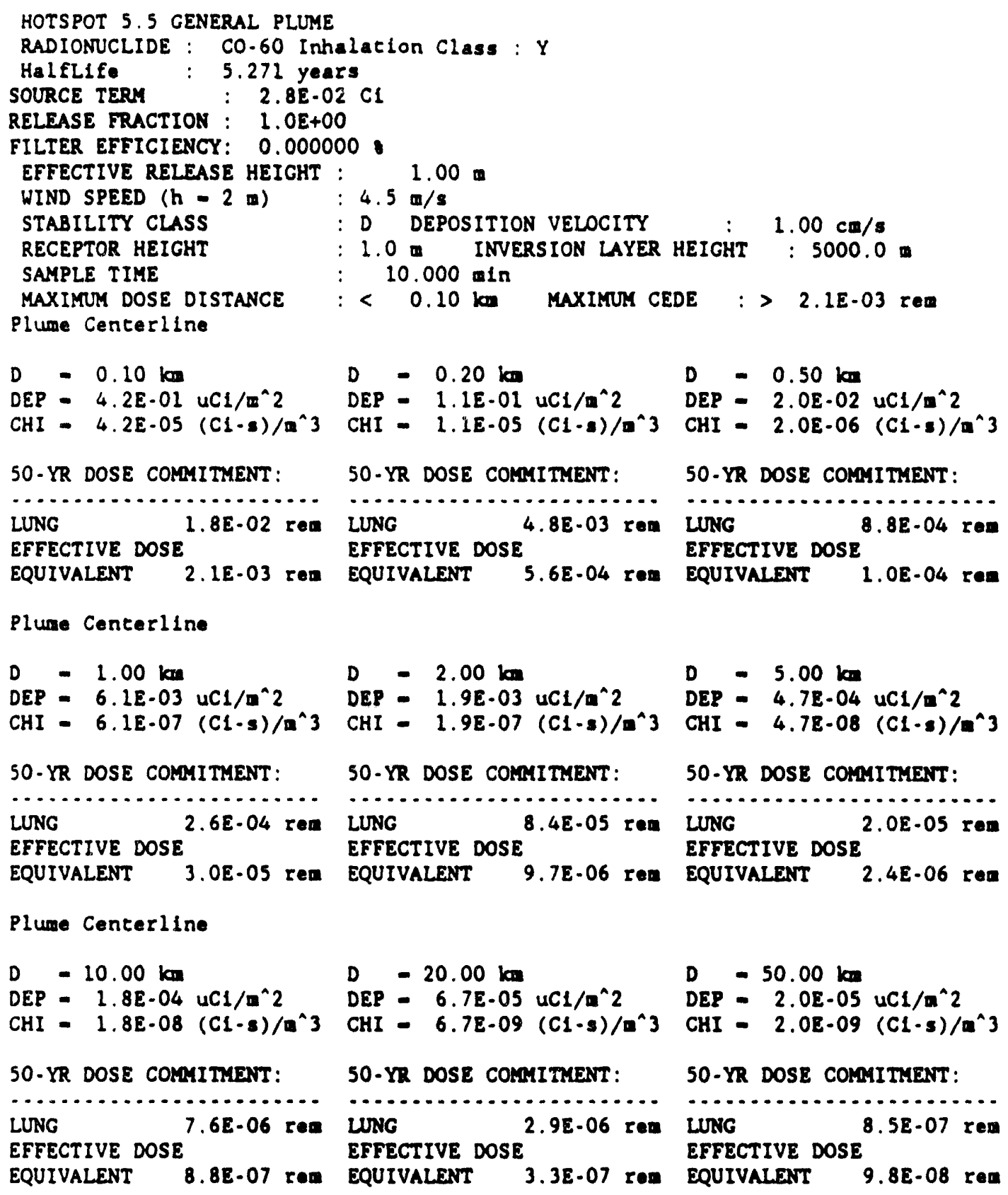




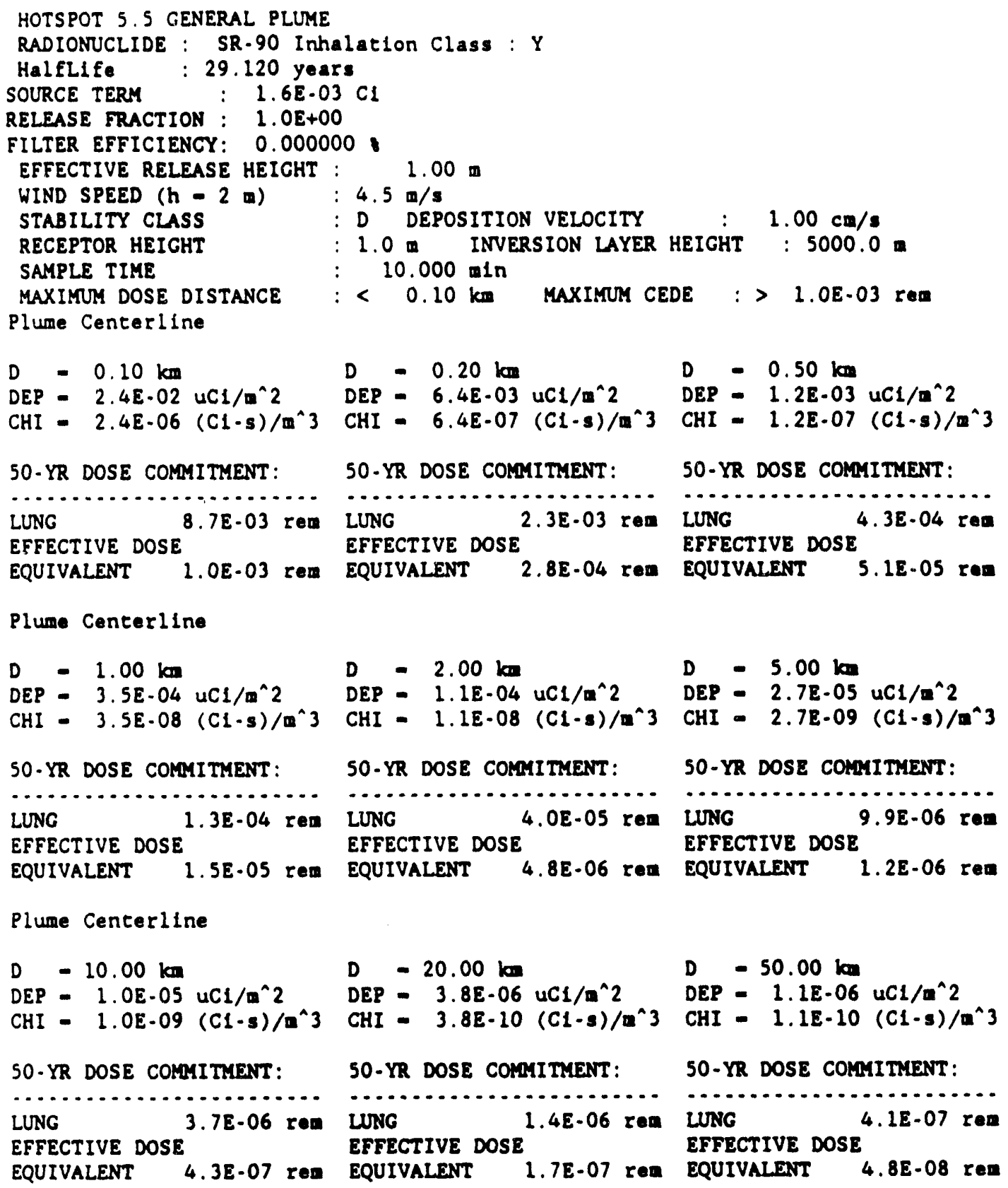




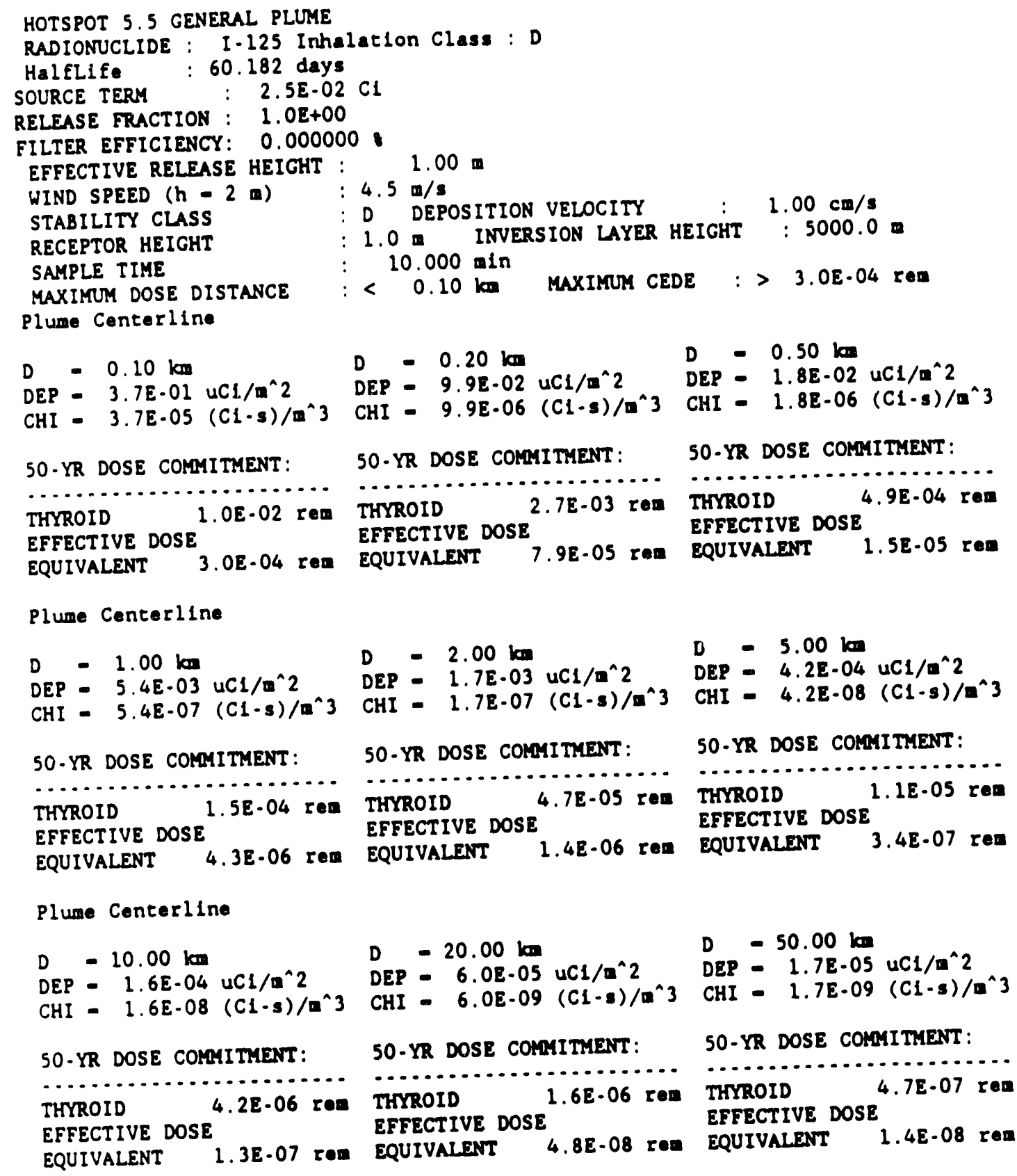




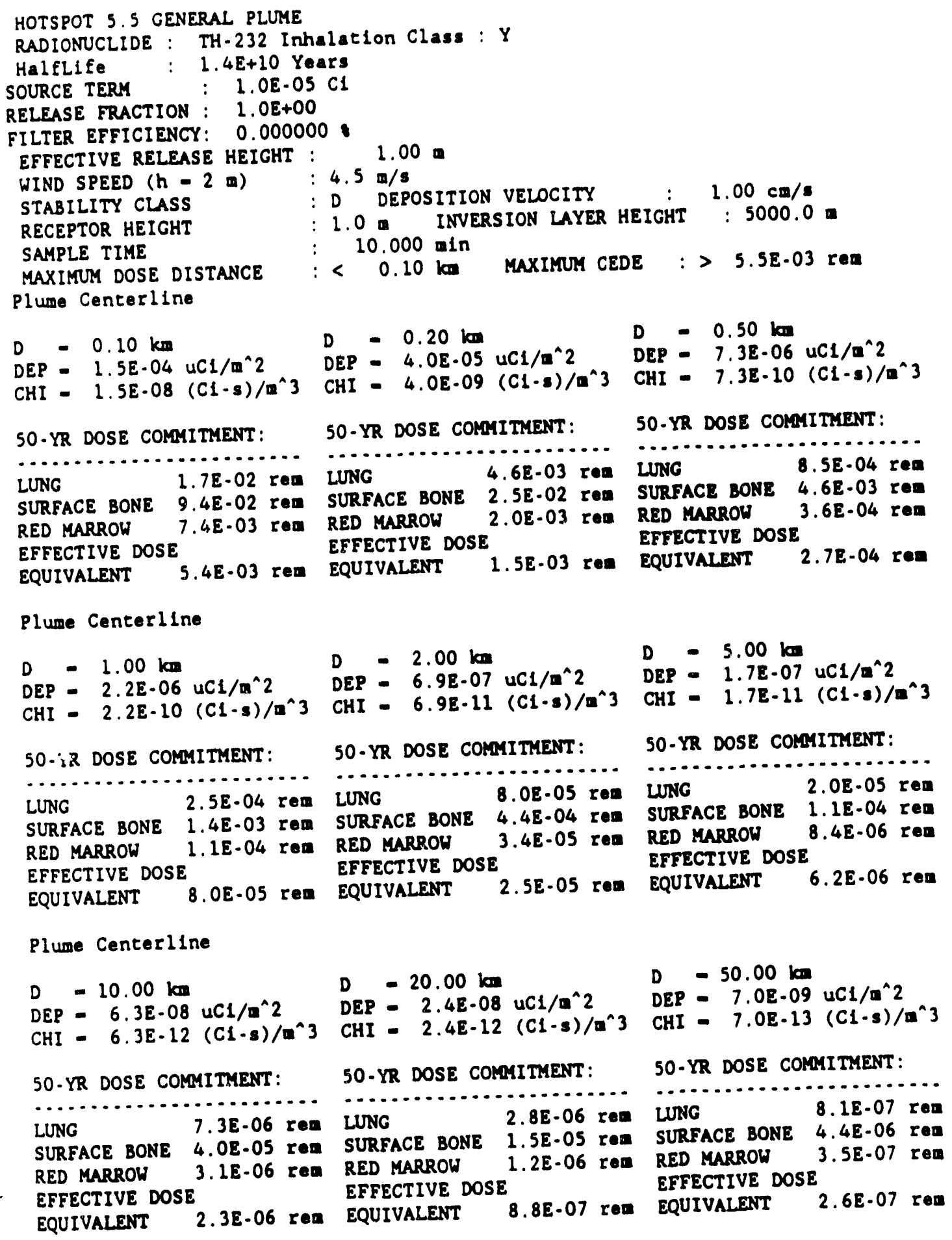




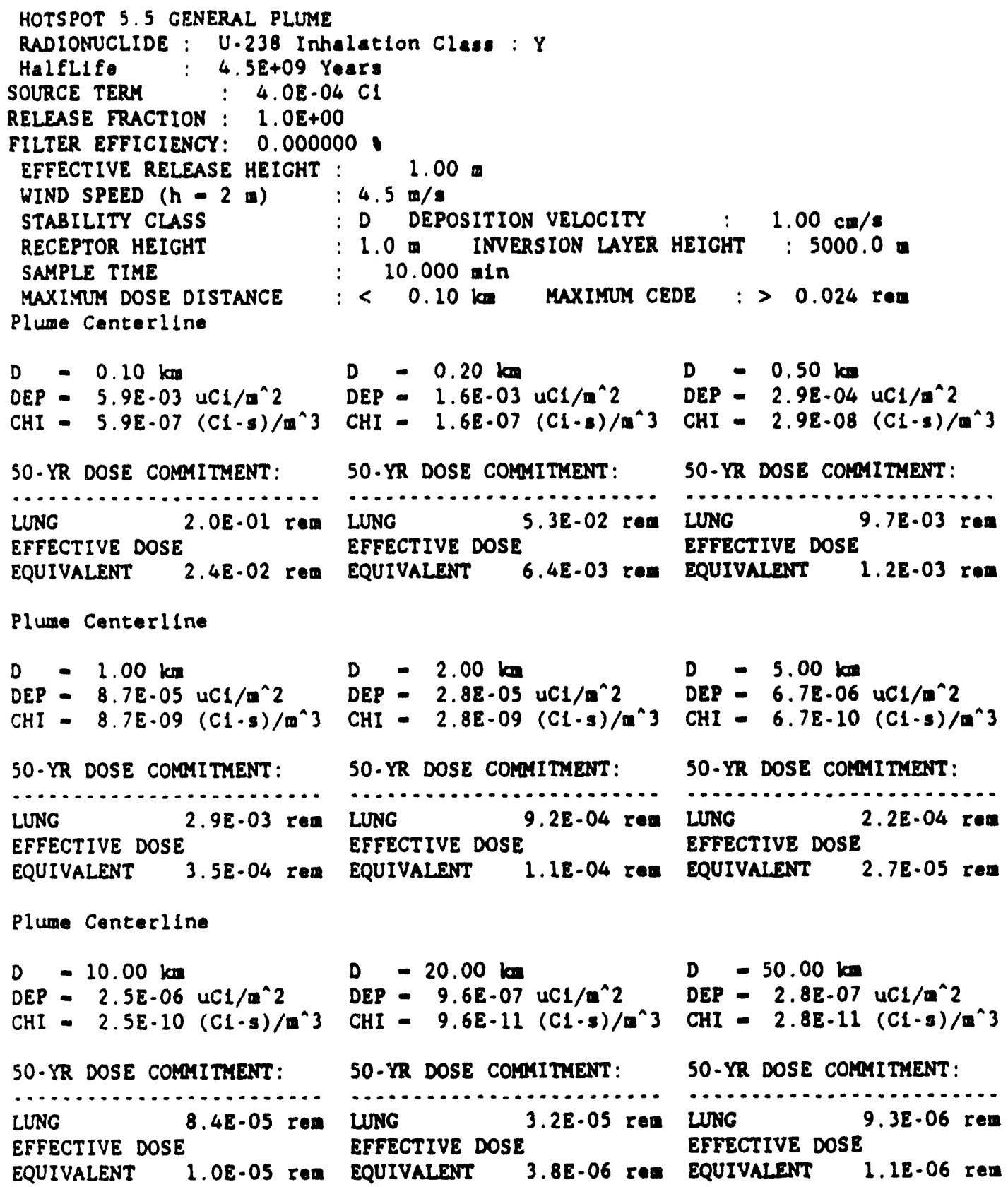




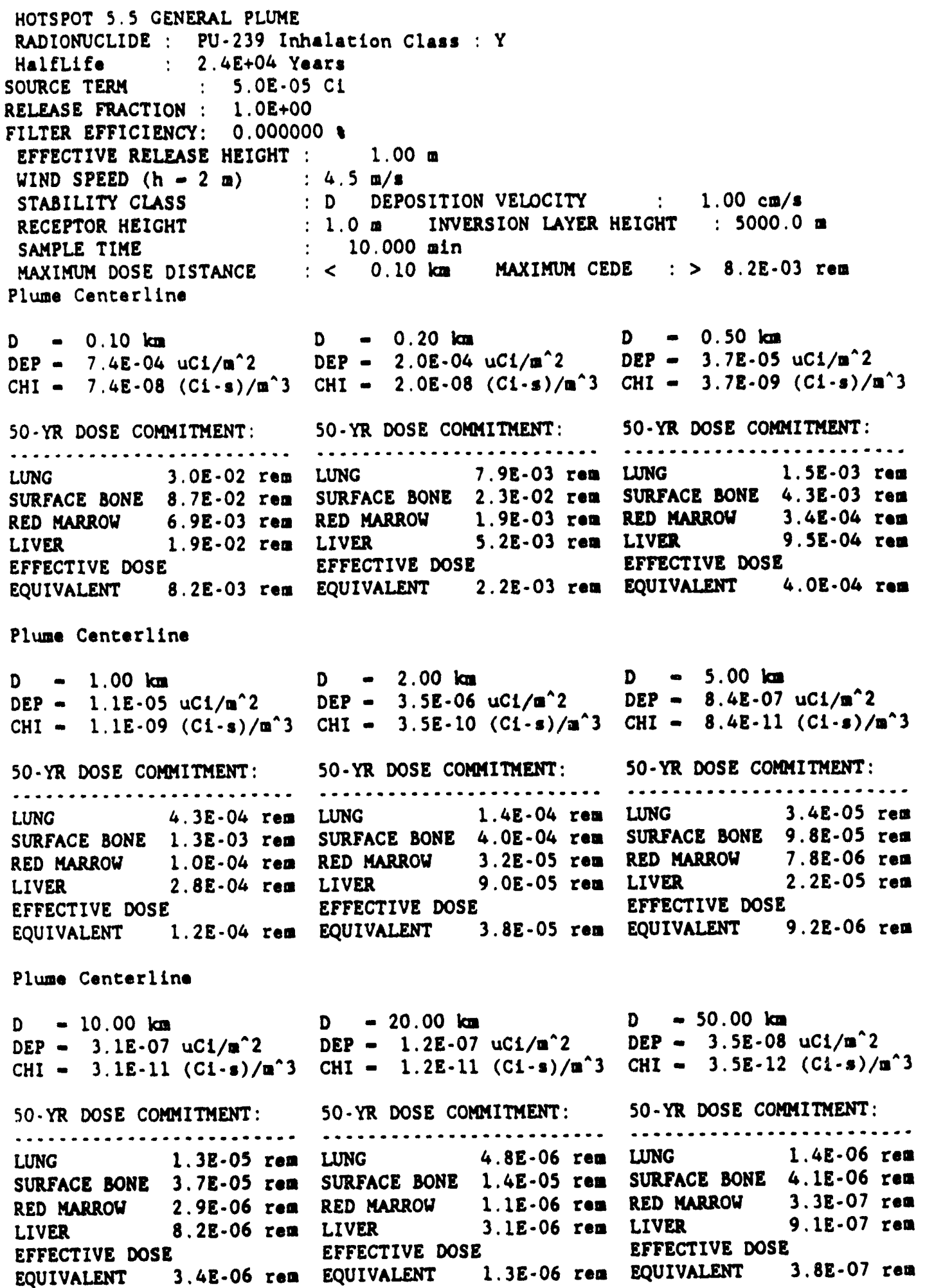


HOTSPOT 5.5 GENERAL PLUME

RADIONUCLIDE: $\mathrm{H} \cdot 3$ Inhalation Class: $\mathrm{D}$

HalfLifo: : 12.350 years

SOURCE TERY : $3.0 \mathrm{E}+04 \mathrm{CI}$

RELEASE FRACTION: $1.0 \mathrm{E}+00$

FILTER EFFICIENCY: 0.000000

EFFECTIVE RELEASE HEIGHT : $1.00 \mathrm{~m}$

WIND SPEED ( $h-2 \mathrm{a}): 4.5 \mathrm{~m} / \mathrm{s}$

STABILITY CLASS

RECEPTOR HEIGHT

SAMPLE TIME

MAXIMUM DOSE DISTANCE

D DEPOSITION VELOCITY : $1.00 \mathrm{~cm} / \mathrm{s}$

1.0 INVERSION LAYER HEIGHT : $5000.0 \mathrm{a}$ $10.000 \mathrm{~min}$

Plume Centerline

$D=0.10 \mathrm{~km}$

$D E P=4.5 E+05 \mathrm{uCl} / \mathrm{m}^{\wedge} 2$

$\mathrm{CHI}=4.5 \mathrm{E}+\mathrm{OI}(\mathrm{Cl}-\mathrm{s}) / \mathrm{a}^{\wedge} 3$

MAXIMUM CEDE : > $1.4 \mathrm{red}$

50.YR DOSE COMAITMENT:

$\begin{array}{lll}\text { SKIN } & 1.4 \mathrm{E}+00 \text { rea } \\ \text { THYROID } & 1.4 \mathrm{E}+00 \text { rea } \\ \text { LUNG } & 1.4 \mathrm{E}+00 \text { rea } \\ \text { SURFACE BONE } & 1.4 \mathrm{E}+00 \text { ren } \\ \text { LIVER } & 1.4 \mathrm{E}+00 \text { rea } \\ \text { SPLEEN } & 1.4 \mathrm{E}+00 \text { red } \\ \text { GONADS } & 1.4 \mathrm{E}+00 \text { ren } \\ \text { EFFECTIVE DOSE } & \\ \text { ERUIVALENT } & 1.4 \mathrm{E}+00 \text { red }\end{array}$

$D E P=1.2 \mathrm{E}+05 \mathrm{uCl} / \mathrm{a}^{\wedge} 2 \quad \mathrm{DEP}=2.2 \mathrm{E}+04 \mathrm{uCl} / \mathrm{a}^{\wedge} 2$

$\mathrm{CHI}=1.2 \mathrm{E}+0 \mathrm{O}(\mathrm{Cl}-\mathrm{s}) / \mathrm{\varpi}^{\wedge} 3 \mathrm{CHI}-2.2 \mathrm{E}+00(\mathrm{Cl} \cdot \mathrm{s}) / \mathrm{a}^{\wedge} 3$

SO-YR DOSE COMAIMENT:

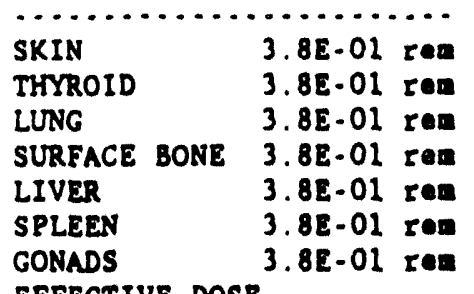

EFEECTIVE DOSE

EQUIVALENT
$3.8 E-01$ rea
50-YR DOSE COMAITMENT:

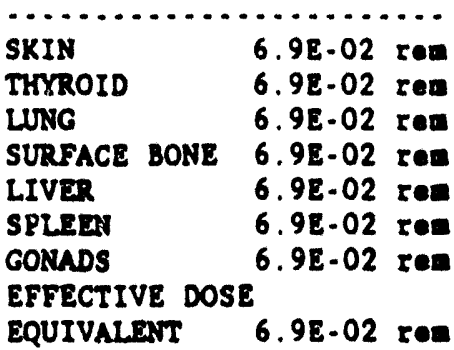

Plume Cencerline

$D=1.00 \mathrm{~km}$
$D E P=6.5 E+03 \mathrm{uCl} / \mathrm{m}^{\wedge} 2$
$C H I=6.5 E .01(\mathrm{Cl}-\mathrm{s}) / \mathrm{m}^{\wedge} 3$

50.YR DOSE COMMITMENT:

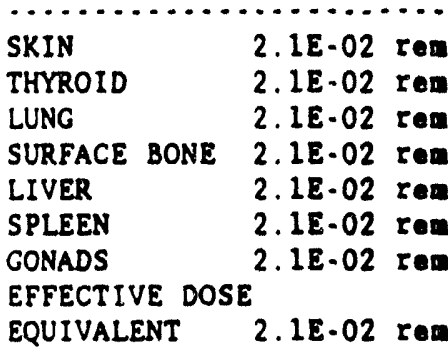

Plume Centerline

$D \quad-10.00 \mathrm{~km}$

DEP $=1.9 E+02 \mathrm{UCL} / \mathrm{m}^{\wedge} 2$

$\mathrm{CHI}=1.9 \mathrm{E} .02(\mathrm{Cl}-\mathrm{s}) / \mathrm{m}^{\wedge} 3$

SO-YR DOSE COMAI TMENT:

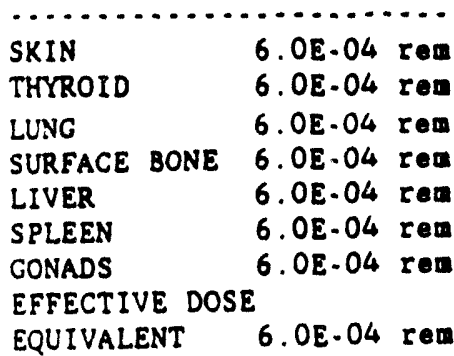

$D \quad-2.00 \mathrm{~km}$

CHI - $2.1 E-01(\mathrm{Cl}-3) / \mathrm{m}^{\wedge} 3$

50-YR DOSE COMAITIENT:

EFFECTIVE DOSE

EQUIVALENT
$D E P=2.1 E+03 \mathrm{uCl} / \mathrm{a}^{\wedge} 2$

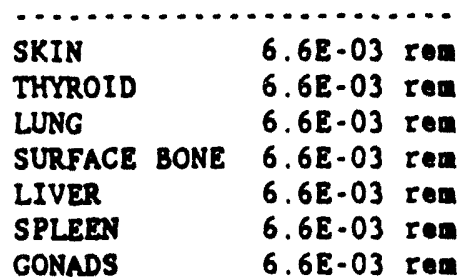

D $\quad-5.00 \mathrm{~km}$

DEP $=5.0 E+02 \mathrm{uC} 1 / \mathrm{m}^{\wedge} 2$

$\mathrm{CHI}=5.0 \mathrm{E} .02(\mathrm{Cl}-\mathrm{s}) / \mathrm{m}^{\wedge} 3$

50-YR DOSE COMAITMENT:

- . . . . . . . . . . . . . . . . .

SKIN $1.6 \mathrm{E}-03 \mathrm{red}$

THYROID $\quad 1.6 \mathrm{E}-03 \mathrm{rem}$

LUNG $1.6 \mathrm{E}-03 \mathrm{rea}$

SURFACE BONE 1.6E-03 reD

LIVER $1.6 \mathrm{E}-03 \mathrm{rem}$

SPLEEN $\quad 1.6 \mathrm{E} .03 \mathrm{rem}$

CONADS $1.6 \mathrm{E} .03$ rea

EFFECTIVE DOSE

EQUIVALENT 1.6E.03 ran

D $\quad-20.00 \mathrm{~km}$

DEP $=7.2 E+01 \mathrm{uCl} / \mathrm{m}^{\wedge} 2$

D $\quad-50.00 \mathrm{~km}$

DEP - $2.1 E+01 \mathrm{uCl} / \mathrm{m}^{\wedge} 2$

CHI - $2.1 E-03(\mathrm{Cl}-\mathrm{s}) / \mathrm{w}^{\wedge} 3$

50-YR DOSE COMAITMENT:

50-YR DOSE COMAITMENT:

\begin{tabular}{|c|c|c|c|c|c|}
\hline SKIN & 2. $3 \mathbf{E} \cdot 04$ & rod & SKIN & $6.6 E-05$ & ren \\
\hline IKYROID & $2.3 \mathrm{E} .04$ & rea & THYROID & & rea \\
\hline & $2.3 E-04$ & $r e a$ & LUNG & & rea \\
\hline $\begin{array}{l}\text { SURFACE BONE } \\
\text { LIVER }\end{array}$ & $\begin{array}{l}2.3 E \cdot 04 \\
2.3 E-04\end{array}$ & rea & $\begin{array}{l}\text { SURFACE BONE } \\
\text { LIVER } \\
\text { SPI FN }\end{array}$ & $\begin{array}{l}6.6 \mathrm{E}-05 \\
6.6 \mathrm{E}-05 \\
6.6 \mathrm{E}-05\end{array}$ & $\begin{array}{ll}r e d \\
r e d\end{array}$ \\
\hline DLEEN & $2.3 \mathrm{E} .04$ & rea & SPLEEN & $\begin{array}{l}6.6 \mathrm{E}-05 \\
6.6 \mathrm{E} .05\end{array}$ & $\begin{array}{l}\text { rea } \\
\text { rem }\end{array}$ \\
\hline $\begin{array}{l}\text { NADS } \\
\text { FECTIVE }\end{array}$ & $2.3 E-04$ & & EFFECTIVE DOS & & \\
\hline IVALENT & $2.3 E \cdot 04$ & & EQUIVALENT & $6.6 \mathrm{E}-05$ & \\
\hline
\end{tabular}




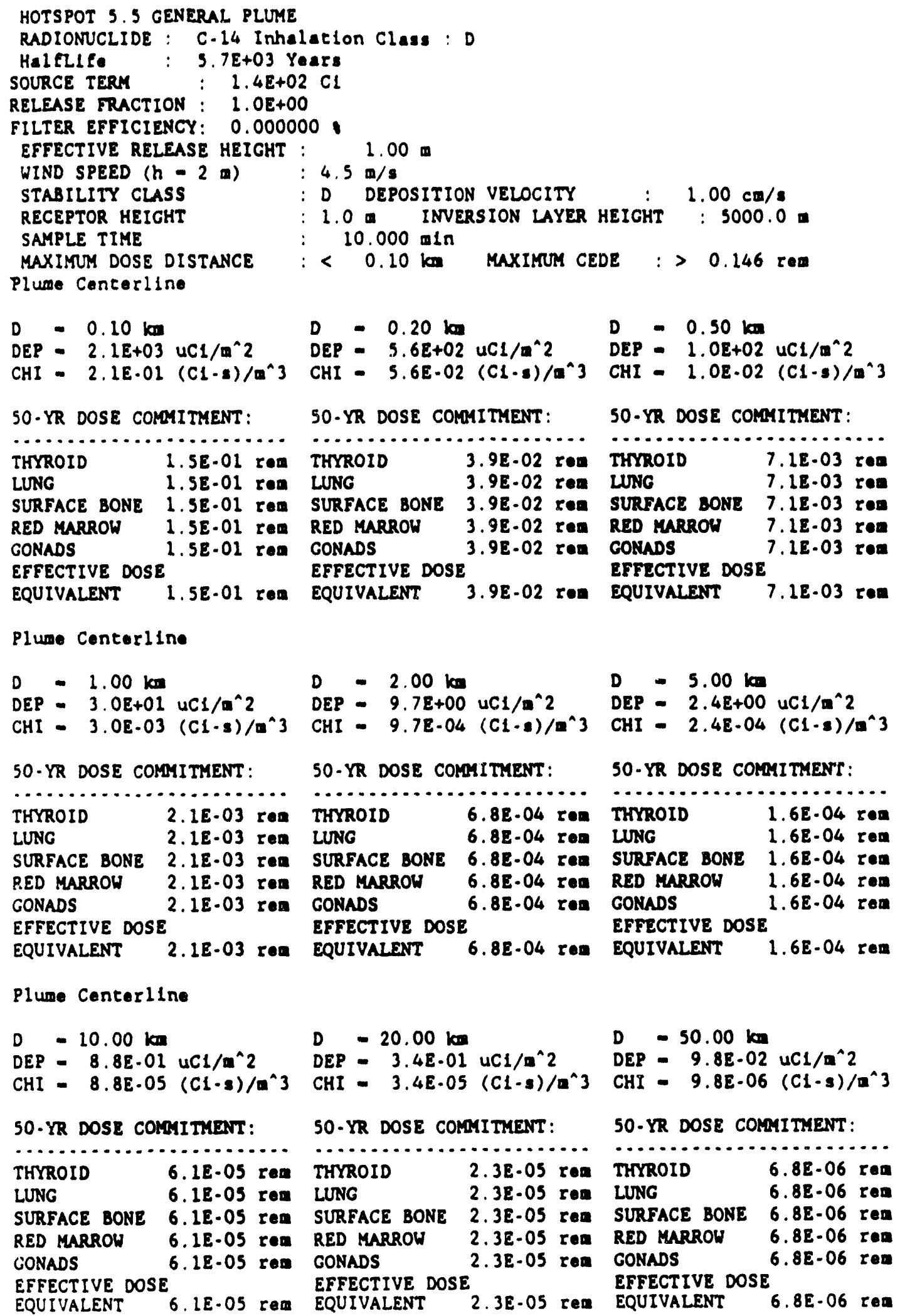




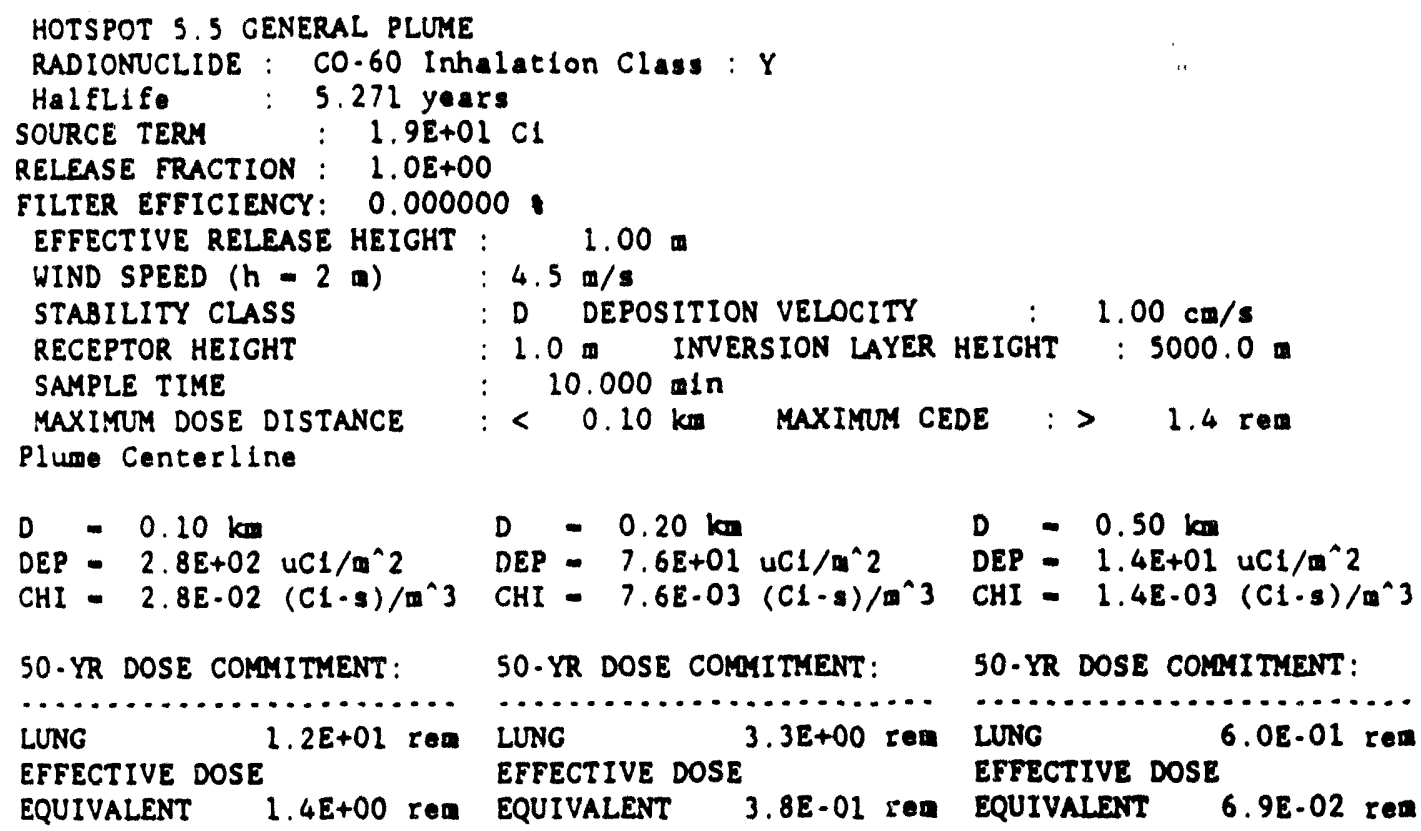

Plume Centerline

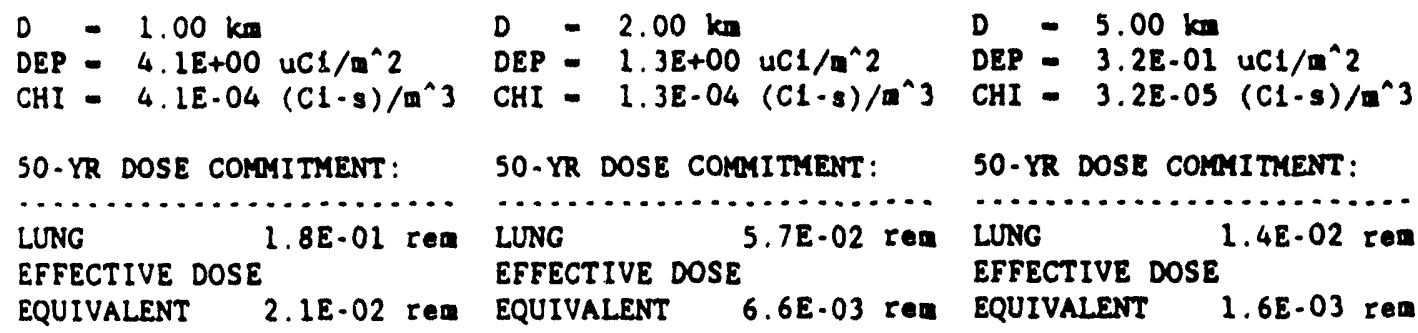

Plume Centerline

\begin{tabular}{|c|c|c|}
\hline $\begin{array}{l}D=10.00 \mathrm{~km} \\
D E P=1.2 E .01 \mathrm{UCl} / \mathrm{w}^{\wedge} 2 \\
C H I=1.2 E .05(\mathrm{Cl}-\mathrm{s}) / \mathrm{a}^{\wedge} 3\end{array}$ & $\begin{array}{l}D=20.00 \mathrm{~km} \\
D E P=4.6 \mathrm{E}-02 \mathrm{uCl} / \mathrm{m}^{\wedge} 2 \\
C H I=4.6 \mathrm{E} .06(\mathrm{Cl}-\mathrm{s}) / \mathrm{a}^{\wedge} 3\end{array}$ & $\begin{array}{l}D=50.00 \mathrm{~km} \\
D E P=1.3 \mathrm{E}-02 \mathrm{uCl} / \mathrm{m}^{\wedge} 2 \\
C H I=1.3 \mathrm{E}-06(\mathrm{Cl}-\mathrm{s}) / \mathrm{m}^{\wedge} 3\end{array}$ \\
\hline -YR DOSE COMMITMENT: & 50.YR DOSE COMAITMENT: & 50.YR DOSE COMAITMENT: \\
\hline $5.2 \mathrm{E}-03 \mathrm{rea}$ & $2.08 .03 \mathrm{rov}$ & $5.7 E .04$ red \\
\hline $\begin{array}{l}\text { FECTIVE DOSE } \\
\text { UIVALENT } 6.0 \text {-04 ren }\end{array}$ & $\begin{array}{l}\text { EFFECTIVE DOSE } \\
\text { EQUIVALENT } 2.3 \mathrm{E} .04 \text { ren }\end{array}$ & $\begin{array}{l}\text { EFFECTIVE DOSE } \\
\text { EQUIVALENT } 6.68-05 \text { red }\end{array}$ \\
\hline
\end{tabular}




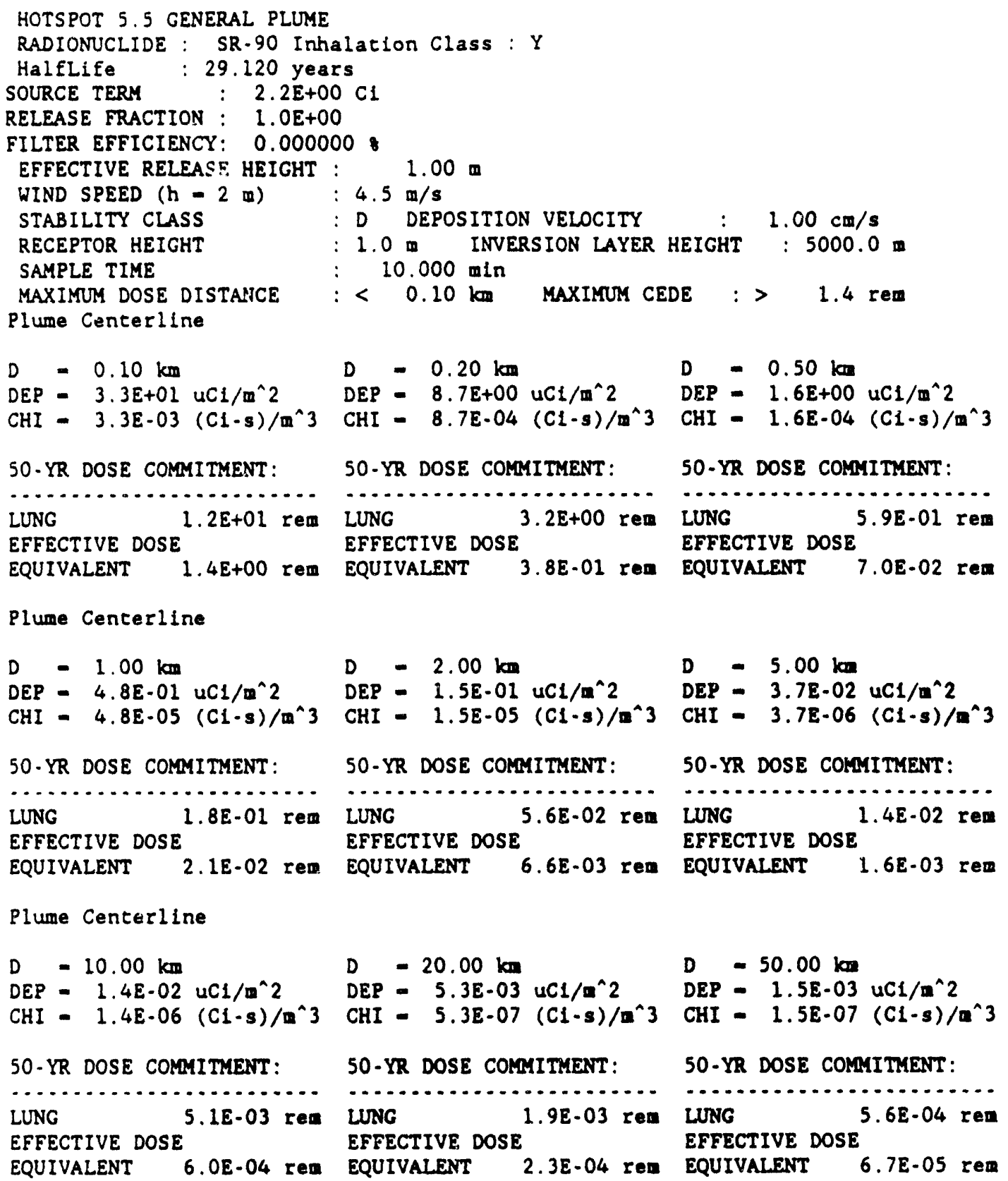




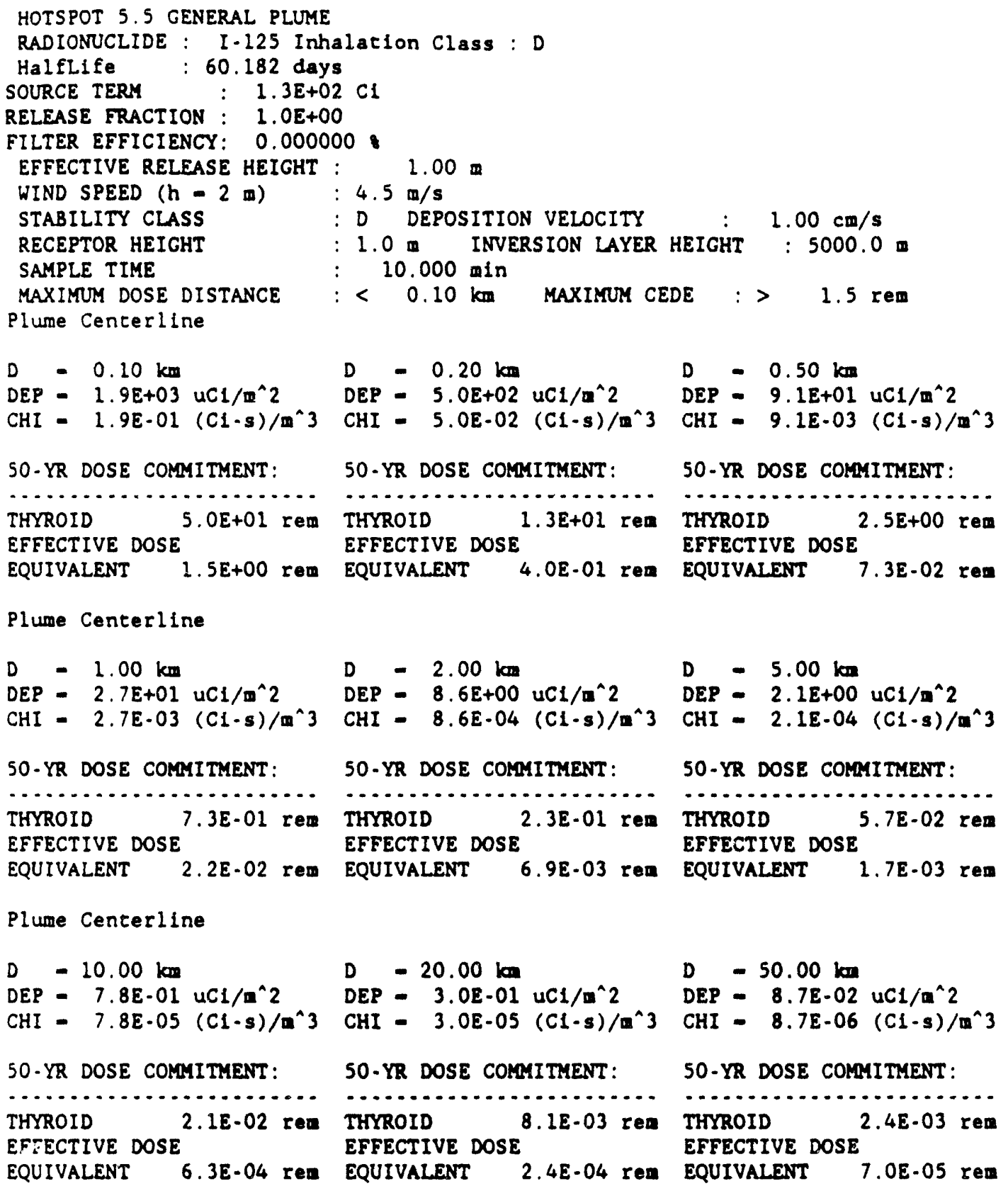


HOTSPOT 5.5 GENERAL FLUME

RADIONUCLIDE : TH-232 Inhalation Class: $Y$

Halflife : $1.4 \mathrm{E}+10$ Years

SOURCE TERM : $1.8 \mathrm{E}-03 \mathrm{Cl}$

RELEASE FRACTION: $1.0 E+00$

FILTER EFFICIENCY: 0.000000

EFFECTIVE RELEASE HEIGHT :

WIND SPEED (h -2 m)

$4.5 \mathrm{~m} / \mathrm{s}$

STABILITY CLASS

RECEPTOR HEICHT

SAMPLE TIME

MAXIMUM DOSE DISTANCE

D DEPOST

: $1.00 \mathrm{~cm} / \mathrm{s}$

Plume Centerlíne

DEP - $2.7 E-02 \mathrm{uCl} / \mathrm{m}^{\wedge} 2$

$1.0 \mathrm{~m}$ INVERSION LAYER HEIGHT : $5000.0 \mathrm{~m}$

10.000 min

$<0.10 \mathrm{~km}$ MAXIMUM CEDE : > $0.981 \mathrm{ren}$

$\mathrm{CHI}=2.7 \mathrm{E}-06(\mathrm{CL}-\mathrm{s}) / \mathrm{m}^{\wedge} 3$

D $\quad-0.20 \mathrm{~km} \quad D=0.50 \mathrm{~km}$

DEP - 7.2E-03 uCl/m² DEP - 1.3E-03 uCl/a^2

50-YR DOSE COMMITMENT:

LUNG

SURFACE BONE 1.7E+01 ren

RED MARROW 1.3E+00 reD

EFFECTIVE DOSE

EQUIVALENT 9.8E-01 ren

$\mathrm{CHI}=7.2 \mathrm{E}-07(\mathrm{Cl}-\mathrm{s}) / \mathrm{m}^{\wedge} 3$

CHI - $1.3 \mathrm{E} .07(\mathrm{CI}-\mathrm{s}) / \mathrm{m}^{\wedge}$

5O-YR DOSE COMAITMENT:

50-YR DOSE COMAITMENT:

\begin{tabular}{|c|c|c|c|c|}
\hline $\begin{array}{l}\text { LUNG } \\
\text { SURFACE BONE } \\
\text { RED MARROW }\end{array}$ & $\begin{array}{l}8.3 \mathrm{E}-01 \\
4.5 \mathrm{E}+0 \mathrm{C} \\
3.6 \mathrm{E}-01\end{array}$ & $\begin{array}{l}\text { ren } \\
\text { ren } \\
\text { ren }\end{array}$ & $\begin{array}{l}\text { LUNG } \\
\text { SURFACE BONE } \\
\text { RED MARROW }\end{array}$ & $\begin{array}{l}1.5 \mathrm{E}-01 \\
8.3 \mathrm{E}-01 \\
6.6 \mathrm{E}-02\end{array}$ \\
\hline IVALENT & $2.6 E-01$ & ren & EQUIVALENT & $4.8 \mathrm{E}-02$ \\
\hline
\end{tabular}

Plume Centerline

$D \quad-2.00 \mathrm{~km}$

$D E P=1.2 E-04 \mathrm{uCl} / \mathrm{m}^{\wedge} 2$

D $\quad-5.00 \mathrm{~km}$

$D E P=3.9 E-04 \mathrm{uCl} / \mathrm{m}^{\wedge} 2$

DEP - 3.0E-05 uC1/ $\mathrm{E}^{\wedge} 2$

CHI - 3.9E-08 (CI-s)/ $\mathrm{m}^{\wedge} 3$

50-YR DOSE COMAIMIENT:

CHI - 3.0E-09 (C1-s)/m^3

50-YR DOSE COMAITMENT:

.......................

LUNG 4.6E.02 rem

SURFACE BONE 2.5E.01 ren

RED MARROW 2.0E-02 ren

EFFECTIVE DOSE

EQUIVALENT

1. 4 E.02 ren

…......................

50-YR DOSE COMAITMENT:

1. 45.02 red

SURFACE BONE 7.9E-02 ren

RED MARROH 6.2E.03 red

EFFECTIVE DOSE

EQUIVALENT

4. 6E-03 ren

UUNG 3.58 .03 .

SURFACE BONE 1.95.02 reA

RED MARROW 1.5E.03 reD

EFFECTIVE DOSE

EQUIVALENT 1.1E.03 ren

Plume Centerline

$D E P=1.1 E .05 \mathrm{uC1} / \mathrm{m}^{\wedge} 2$

$D \quad-20.00 \mathrm{~km}$

D $\quad-50.00 \mathrm{~km}$

$C H I=1.1 E-09(\mathrm{CI}-3) / \mathrm{E}^{\wedge}$

DEP - 4.3E.06 uCl/m^2

DEP - $1.3 E-06 u C i / \mathrm{m}^{\wedge} 2$

50-YR DOSE COMAITHENT:

50-YR DOSE COMAIMENT:

LUNG

$1.35 .03 \mathrm{ren}$

........................

LUNG 5.0E.04 ren

SURFACE BONE 7.18.03 rOD SURFACE BONE 2.7E-03 reA

RED MARROW 5.6E-04 reQ

RED MARROW 2.2E-04 ren

EFFECTIVE DOSE

EFFECTIVE DOSE

EQUIVALENT

4.1E-04 ren

EQUIVALENT

$1.6 \mathrm{E}-04 \mathrm{ren}$

$\mathrm{CHI}=1.3 \mathrm{E}-10(\mathrm{CL}-\mathrm{s}) / \mathrm{m}^{\wedge} 3$

50-YR DOSE COMAITMENT:

......................

LUNG 1.58 .04 ren

SURFACE BONE 8.0E-04 rea RED MARROW 6.3E-05 ren EFFECTIVE DOSE

EQUIVALENT 4.6E-05 ren 


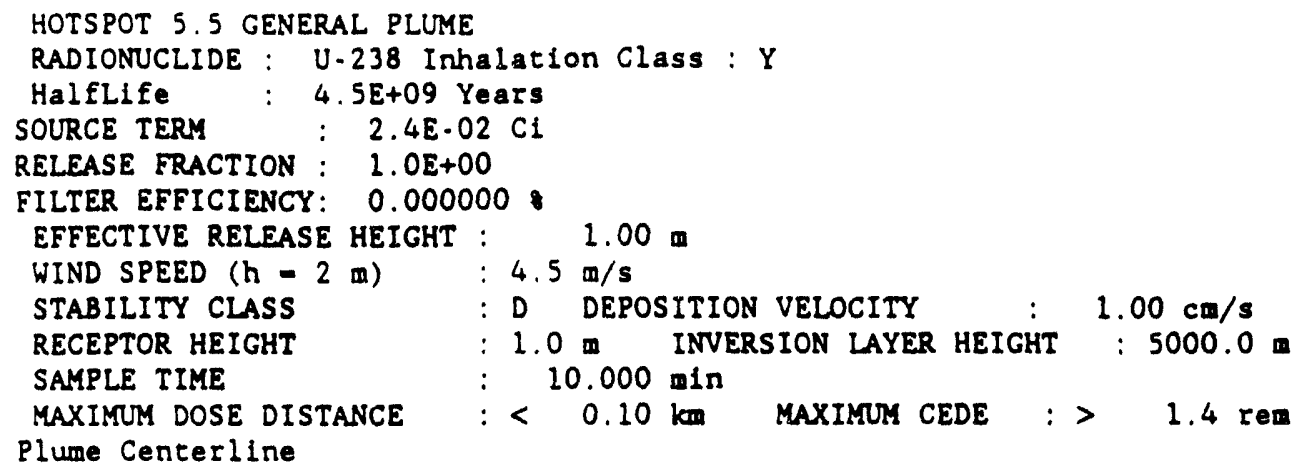

Plume Centerline

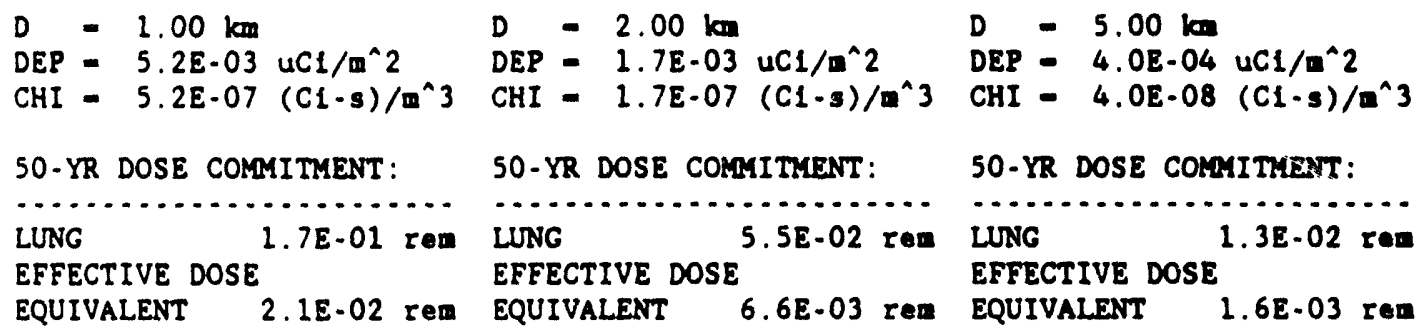

Plume Centerline

\begin{tabular}{|c|c|c|}
\hline $\begin{array}{l}D=10.00 \mathrm{~km} \\
D E P=1.5 \mathrm{E}-04 \mathrm{uCI} / \mathrm{m}^{\wedge} 2 \\
C H I=1.5 \mathrm{E}-08(\mathrm{CI}-\mathrm{s}) / \mathrm{m}^{\wedge} 3\end{array}$ & $\begin{array}{l}D=20.00 \mathrm{~km} \\
D E P=5.7 E-05 \mathrm{uCl} / \mathrm{m}^{\wedge} 2 \\
C H I=5.7 E-09(\mathrm{CI}-\mathrm{s}) / \mathrm{a}^{\wedge} 3\end{array}$ & $\begin{array}{l}D=50.00 \mathrm{~km} \\
D E P=1.7 \mathrm{E}-05 \mathrm{uCI} / \mathrm{m}^{\wedge} 2 \\
C H I=1.7 \mathrm{E}-09(\mathrm{CI}-\mathrm{s}) / \mathrm{m}^{\wedge} 3\end{array}$ \\
\hline 50-YR DOSE COMAITMENT: & 50-YR DOSE COMMITMENT: & 50-YR DOSE COMMITMENT: \\
\hline 5.0E-03 ren & $1.9 \mathrm{E}-03$ ren & $5.6 \mathrm{E}-04$ rem \\
\hline $\begin{array}{l}\text { EFFECTIVE DOSE } \\
\text { EQUIVALENT } \quad 6.0 \text { E.04 rem }\end{array}$ & 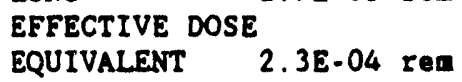 & $\begin{array}{l}\text { EFFECTIVE DOSE } \\
\text { EQUIVALENT } 6.7 \text { E.05 rem }\end{array}$ \\
\hline
\end{tabular}




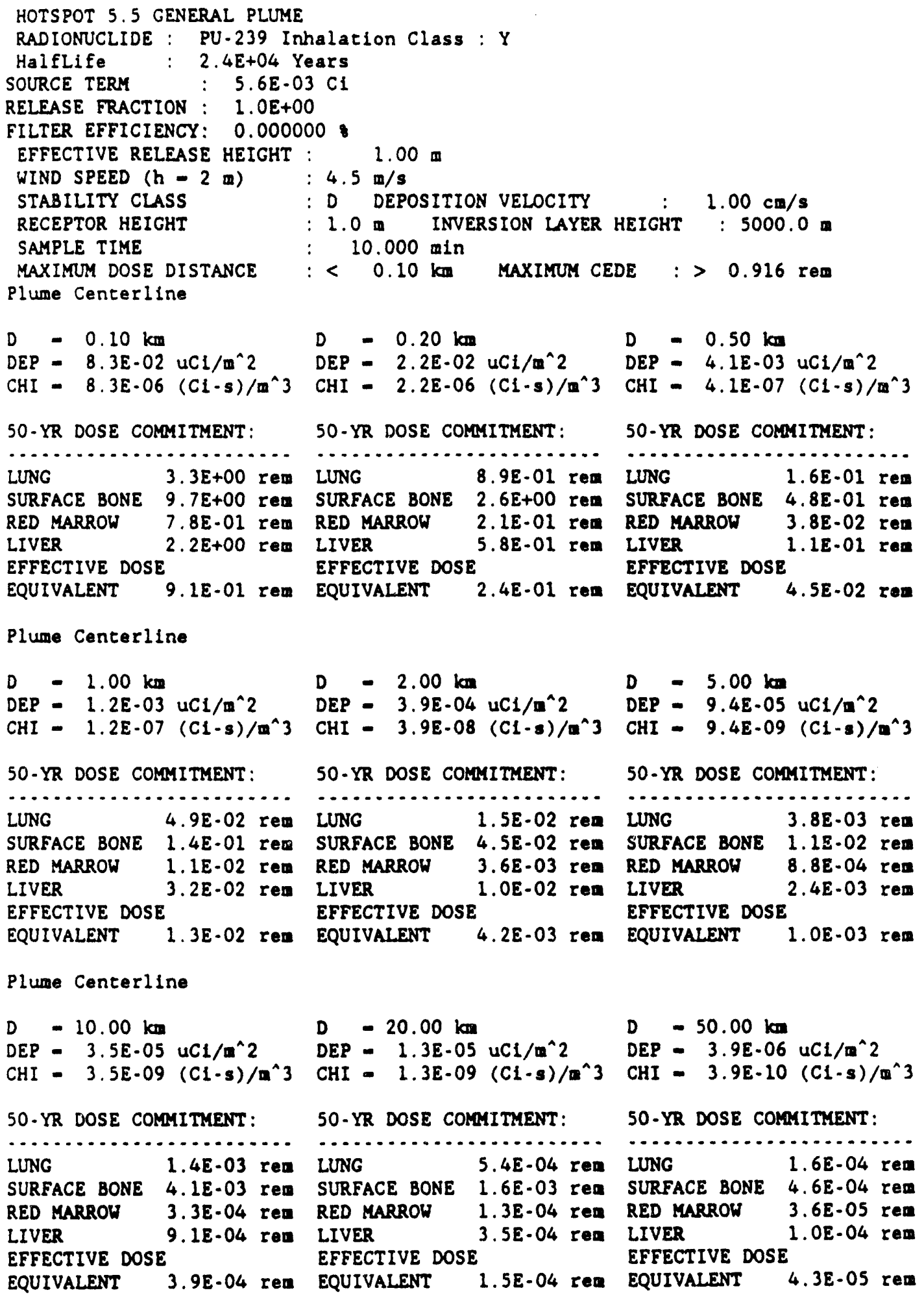




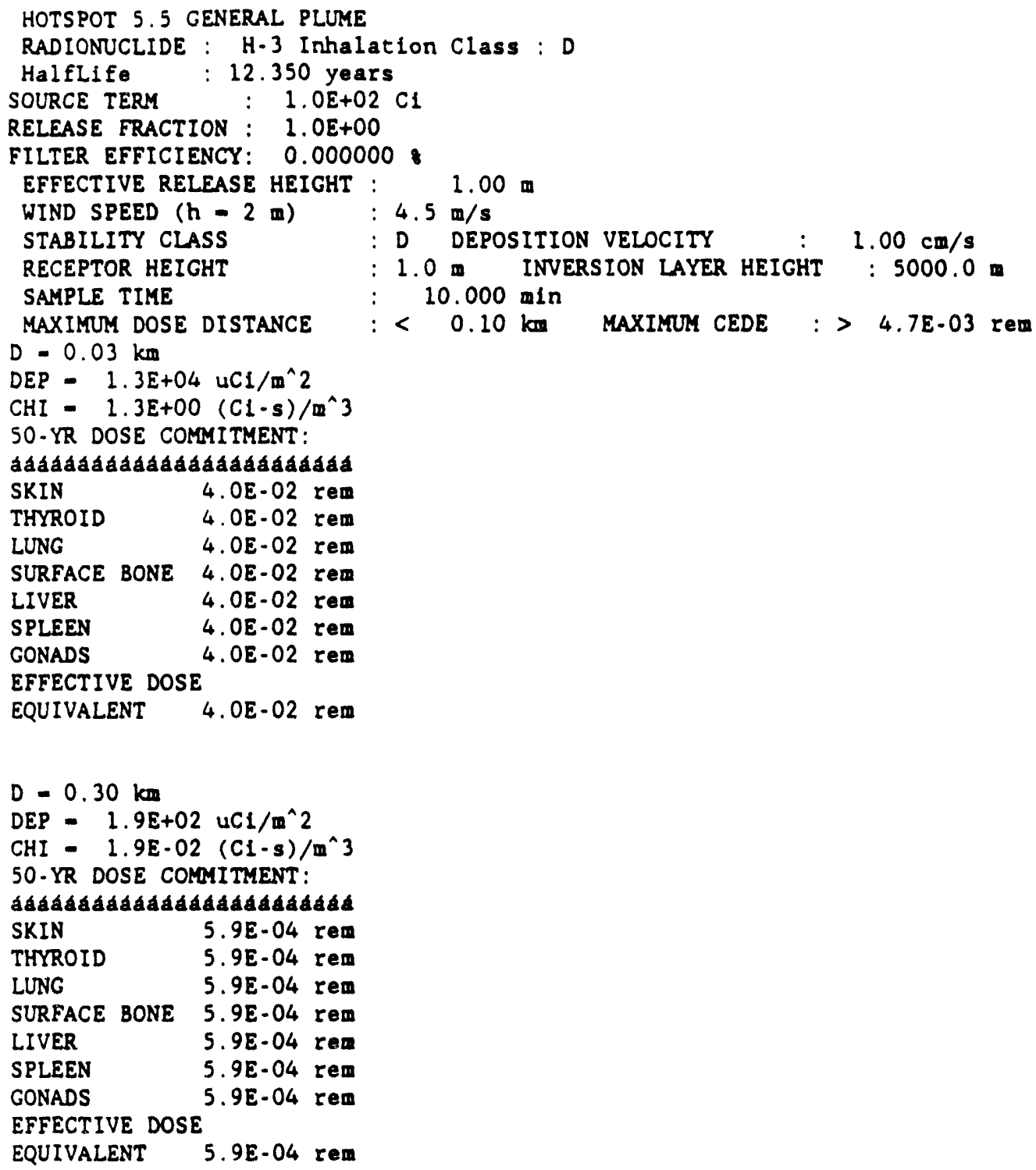

HOTSPOT 5.5 GENERAL PLUME 


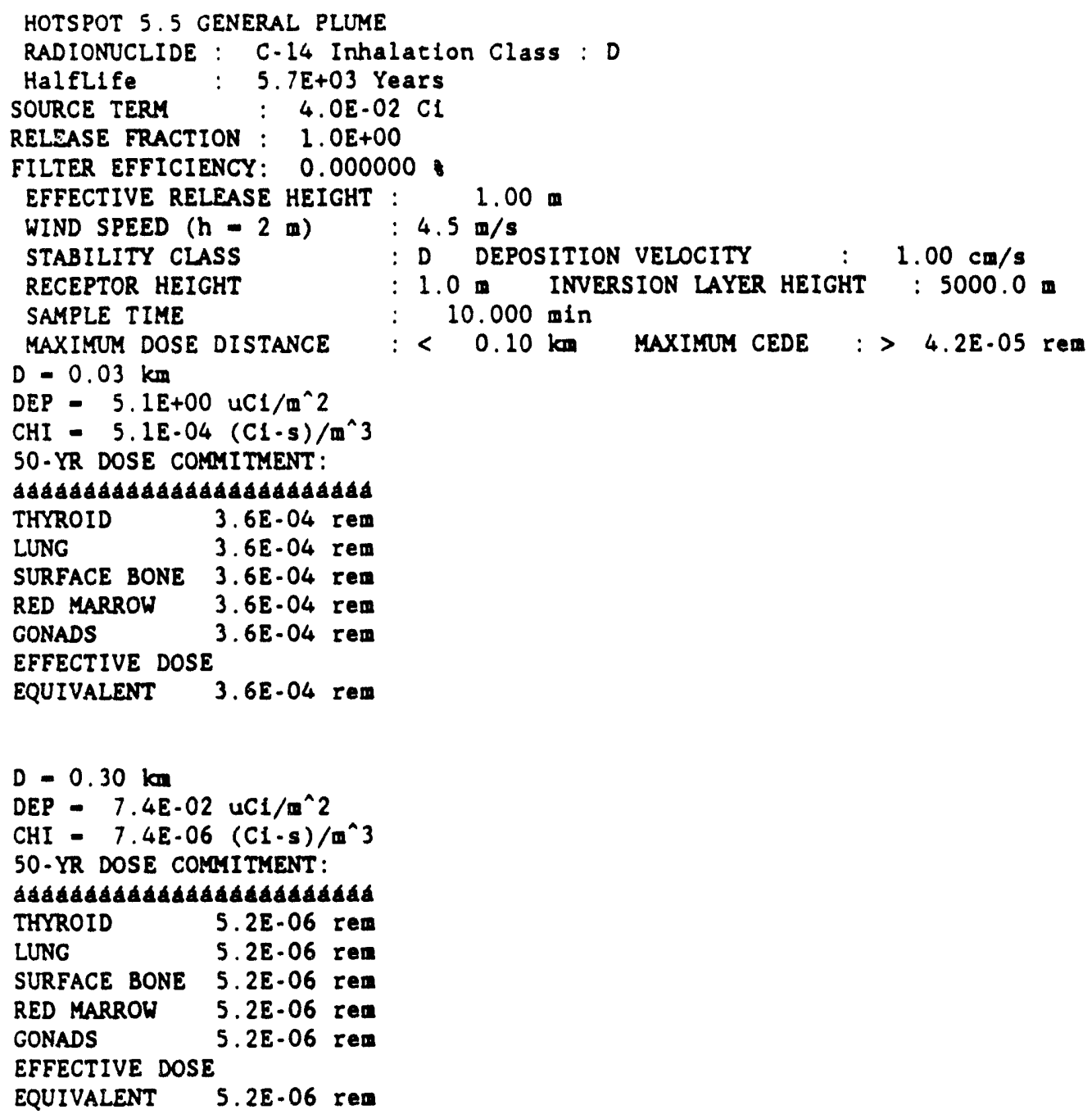

HOTSPOT 5.5 GENERAL PLUME

RADIONUCLIDE : SR-90 Inhalation Class : $Y$

Halflife : 29.120 years

SOURCE TERY : $1.6 \mathrm{E}-03 \mathrm{CI}$

RELEASE FRACTION : $1.0 \mathrm{E}+00$

FILTER EFFICIENCY: 0.000000

EFFECTIVE RELEASE HEIGHT : WIND SPEED ( $h-2$ a)

STABILITY CLASS $4.5 \mathrm{~m} / \mathrm{s}$ RECEPTOR HEIGHT SAMPLE TIME MAXIMUM DOSE DISTANCE : D DEPOSITION VELOCITY : $1.00 \mathrm{~cm} / \mathrm{s}$ $D=0.03 \mathrm{~km}$ DEP - 2.0E-01 uCl/m^2

$\mathrm{CHI}=2.0 \mathrm{E}-05(\mathrm{CL}-\mathrm{s}) / \mathrm{m}^{\wedge} 3$ 50-YR DOSE COMAITMENT:

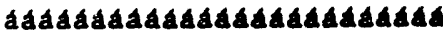
: $1.0 \mathrm{~m}$ INVERSION LAYER HEIGHT : $5000.0 \mathrm{~m}$ $10.000 \mathrm{~min}$

$:<0.10 \mathrm{~km}$ MAXIMUM CEDE : 1.0E-03 rea LUNG 7.5E.02 rem EFFECTIVE DOSE
EQUIVALENT
8.9E-03 rem 


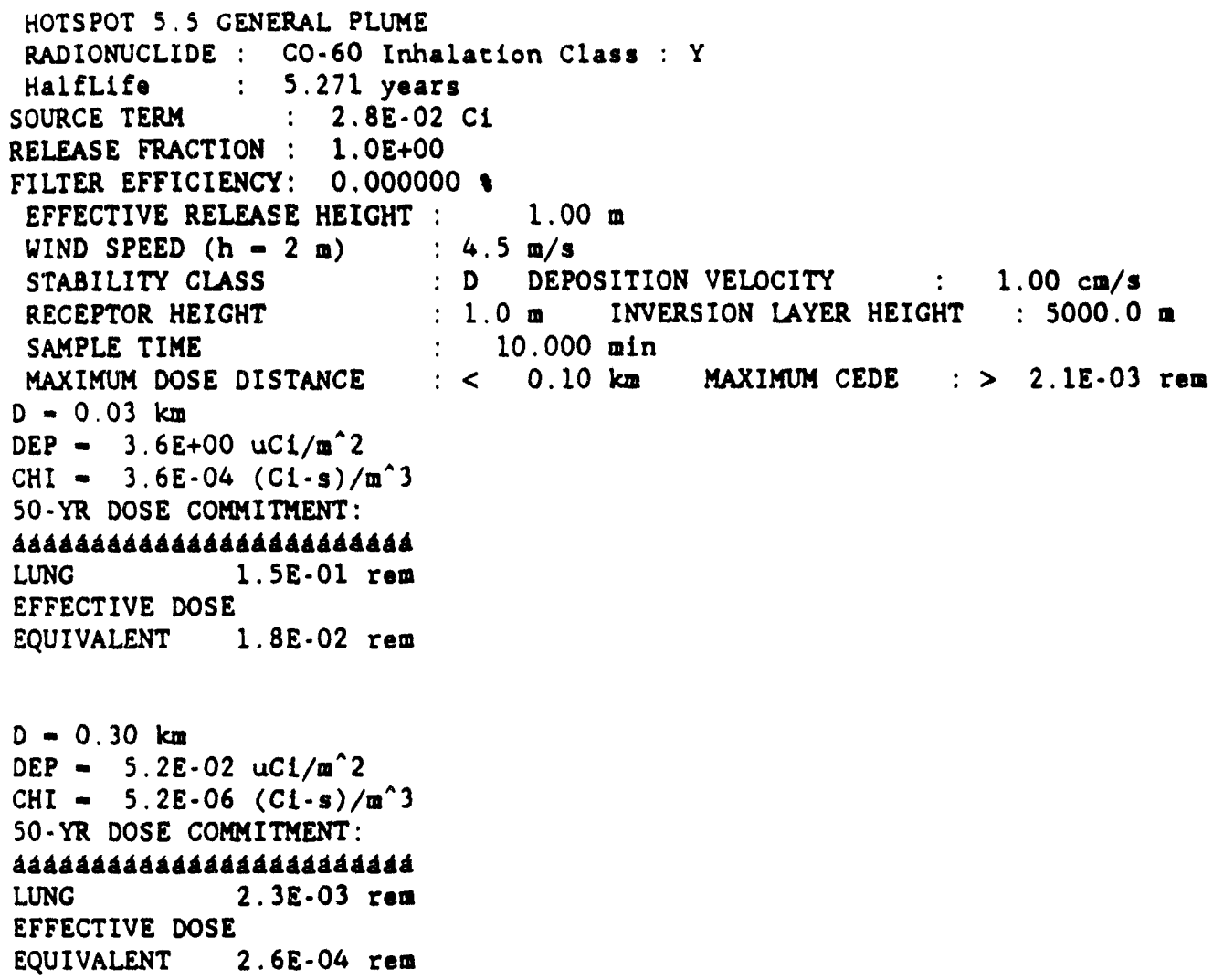




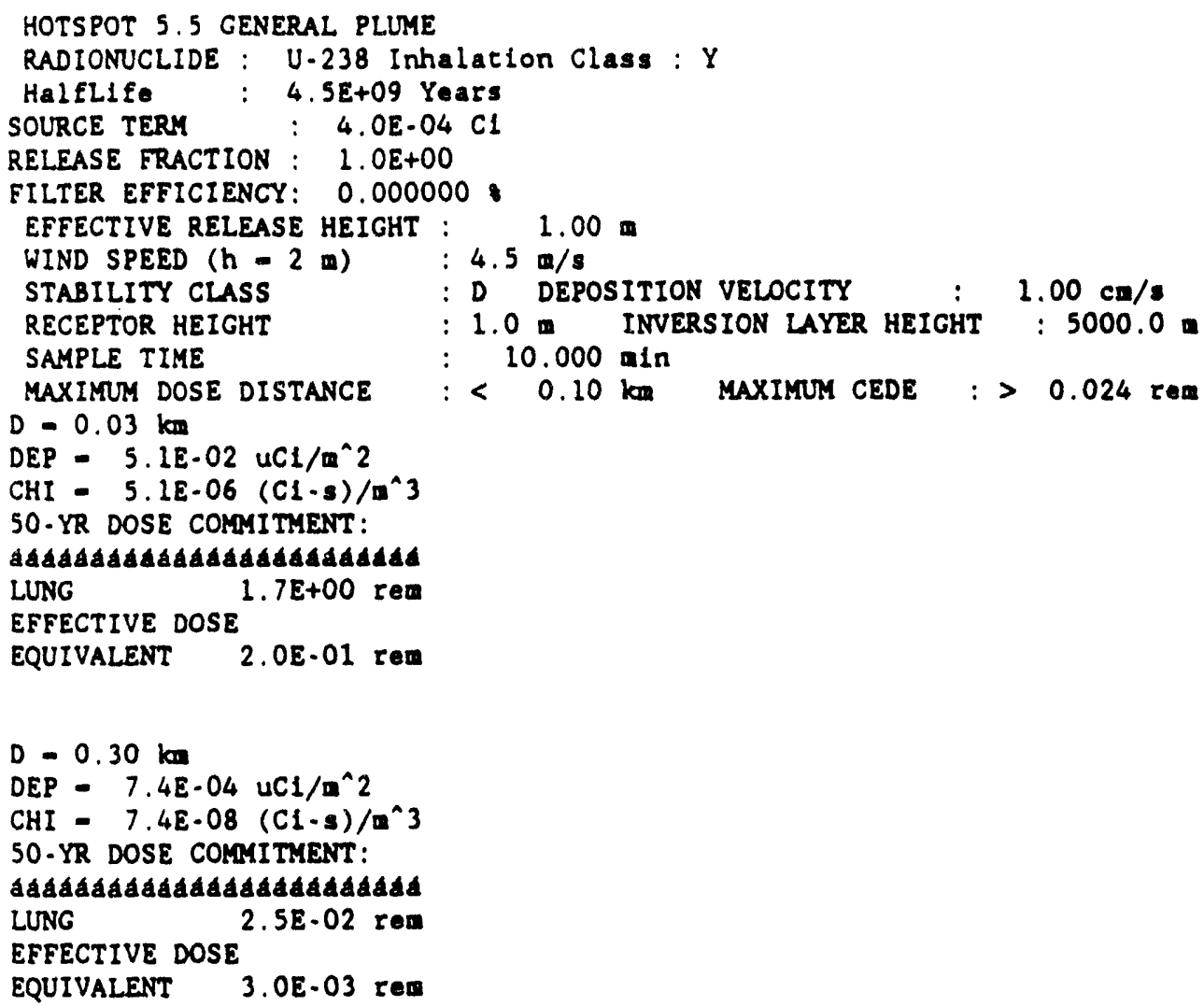




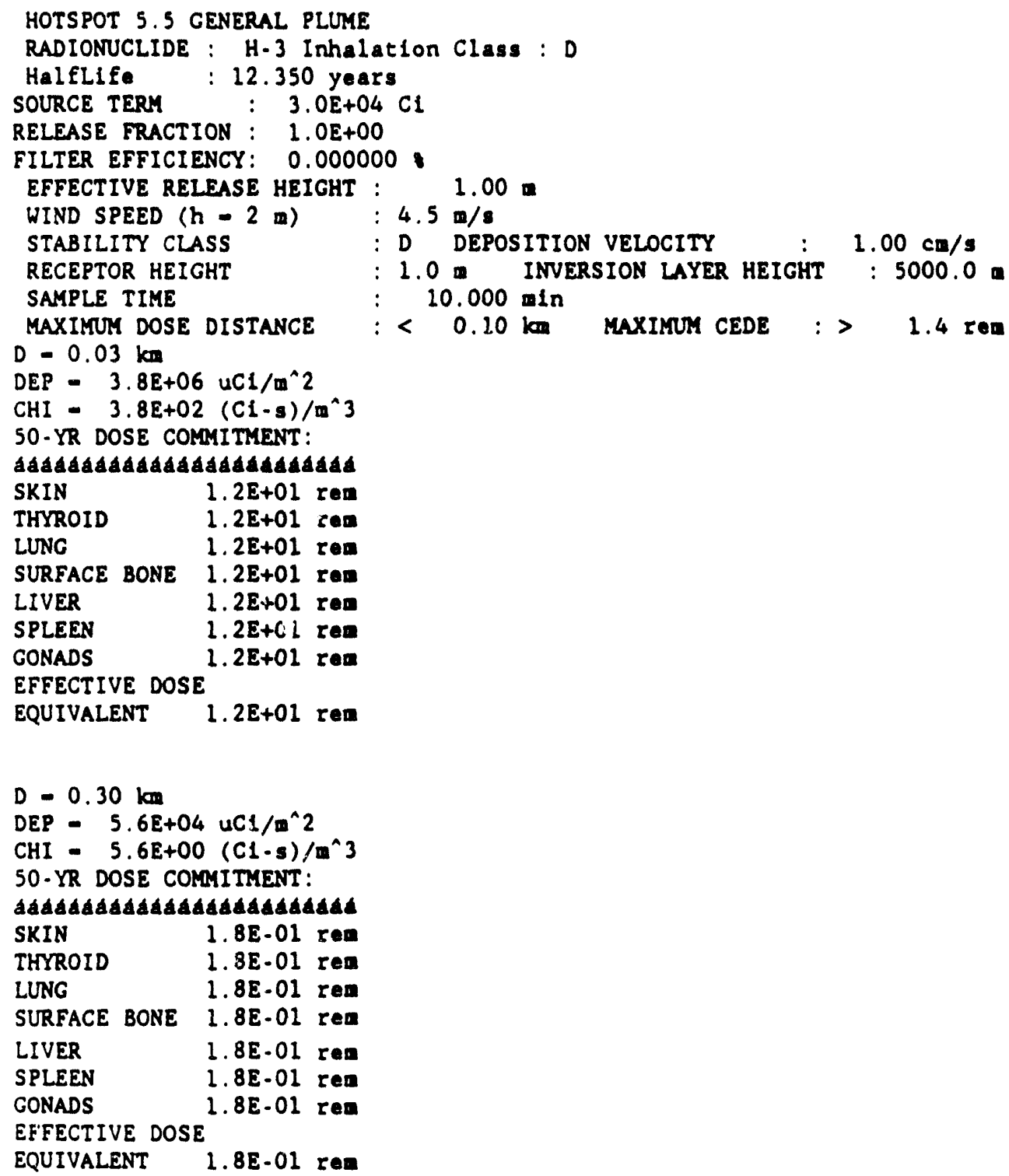




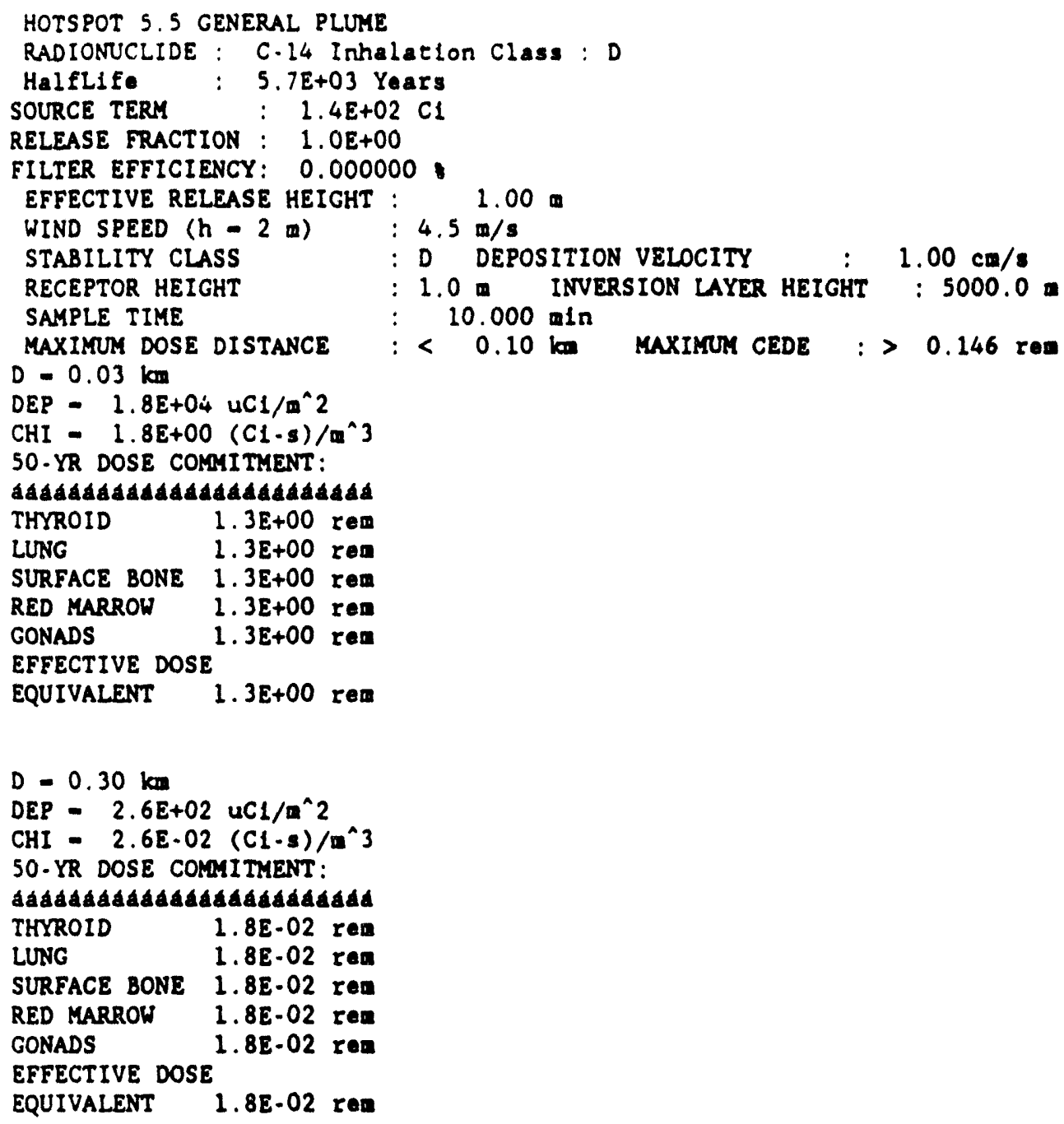

HOTSPOT 5.5 GENERAL PLUME 


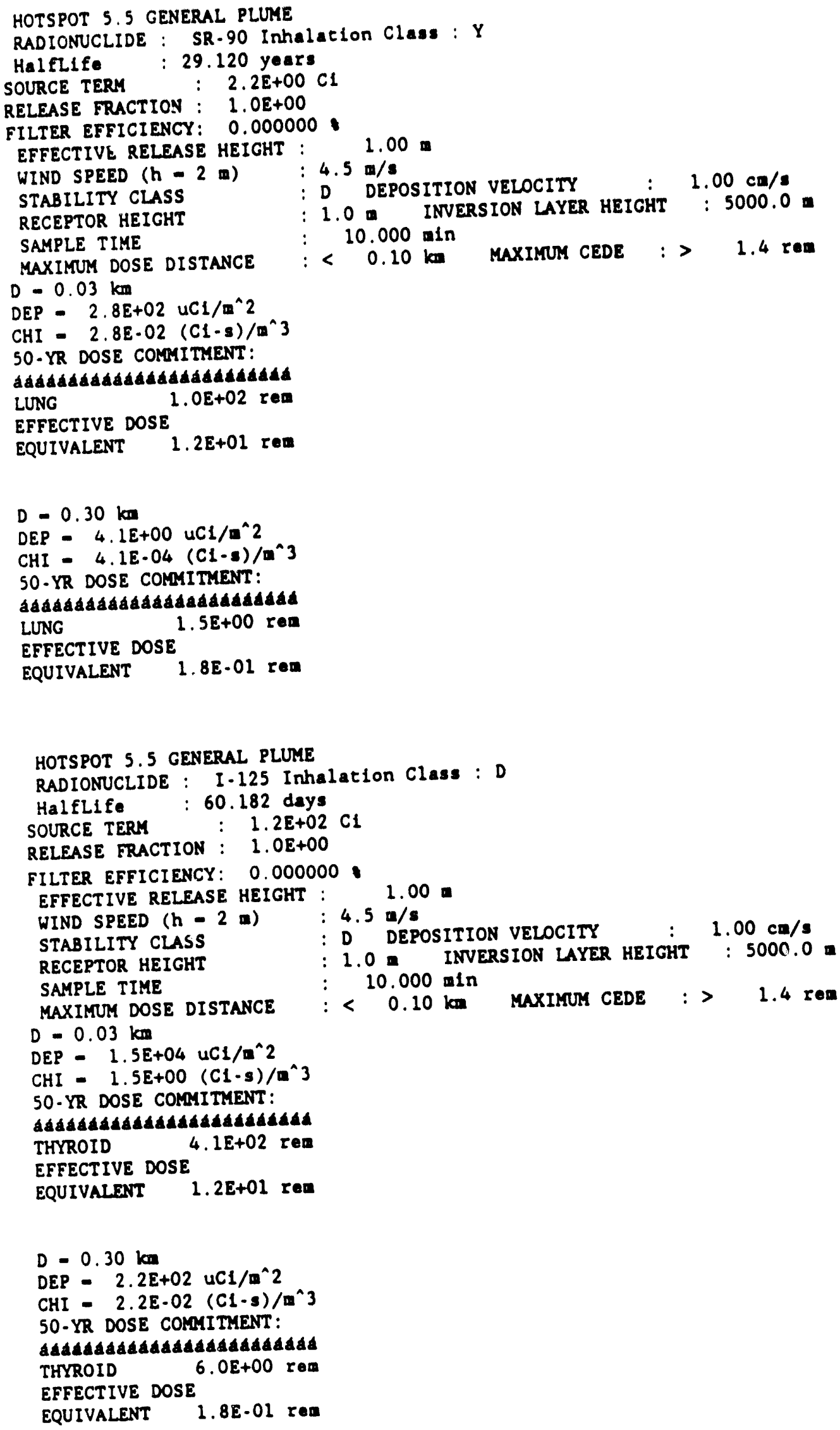




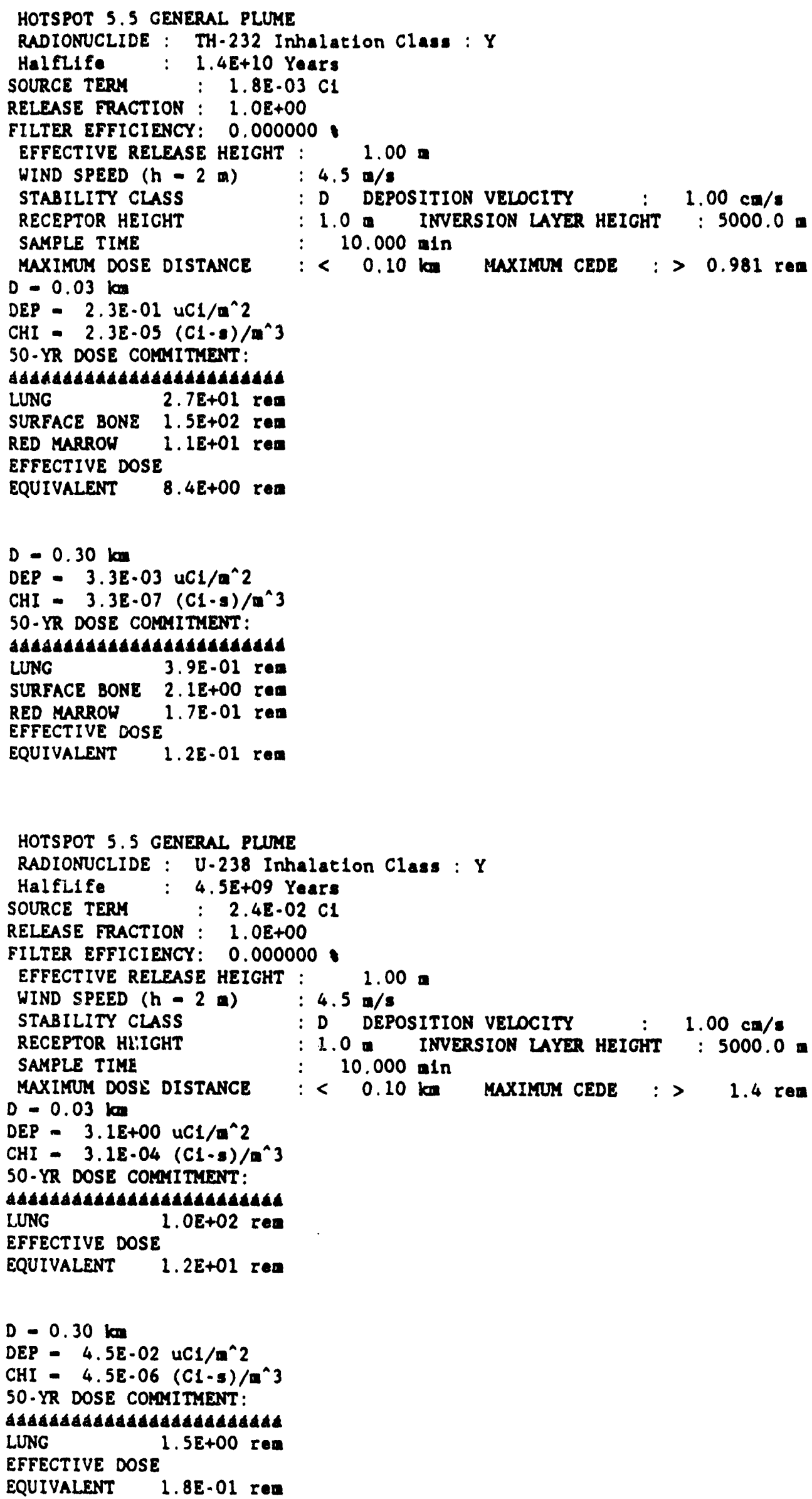



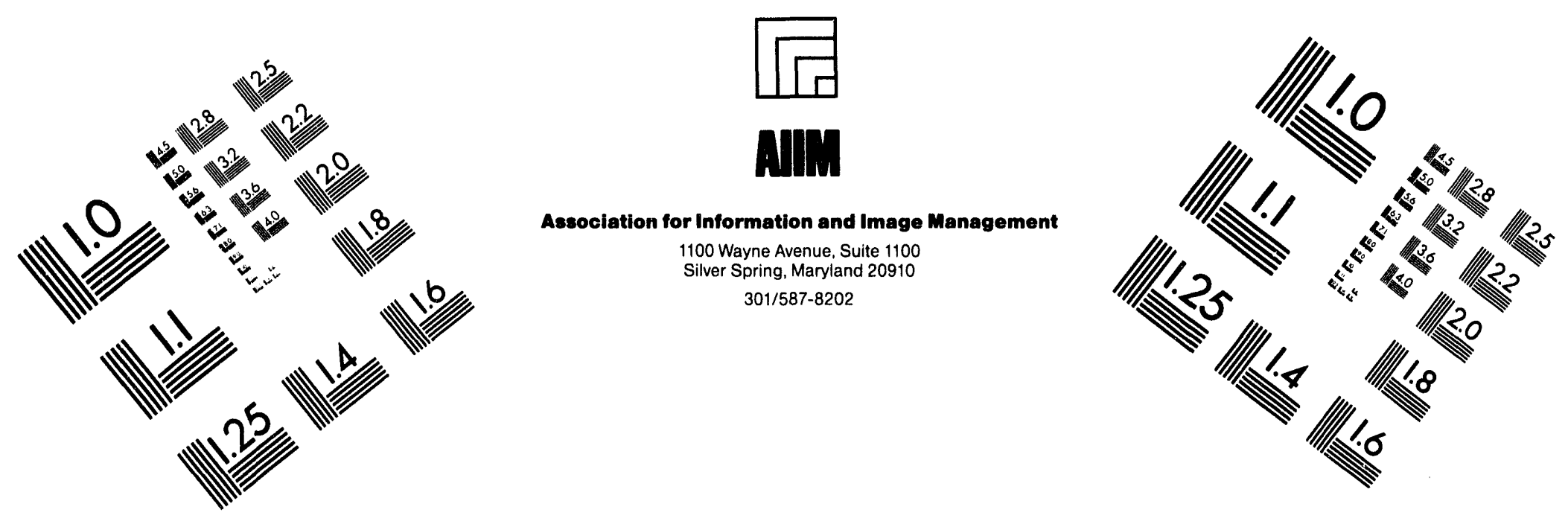

\section{Centimeter}

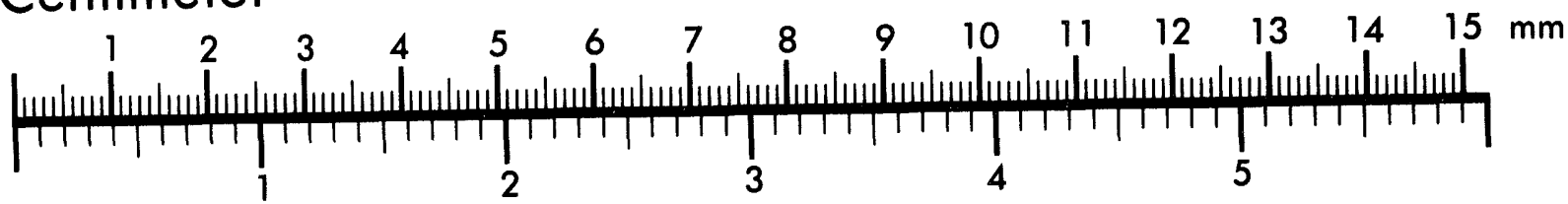
Inches
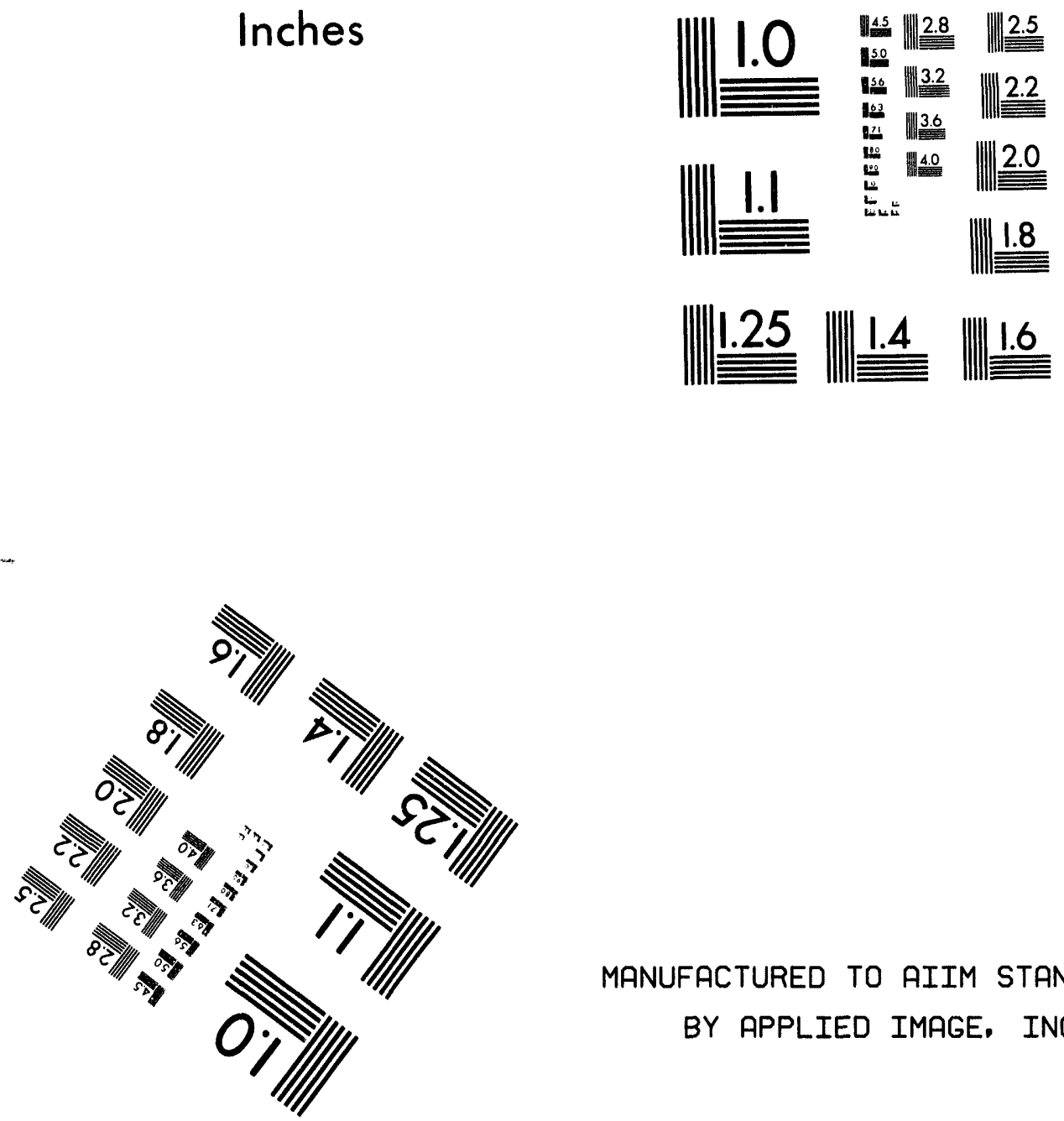

MANUFACTURED TO AIIM STANDARDS BY APPLIED IMAGE. INC.

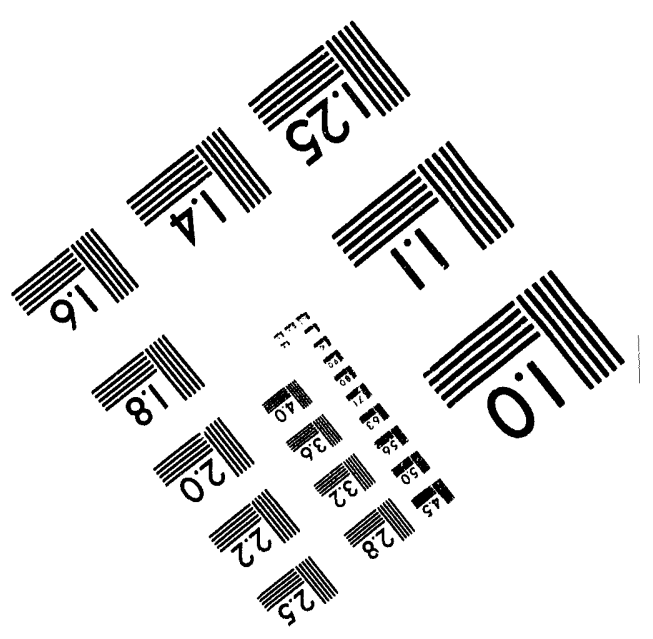



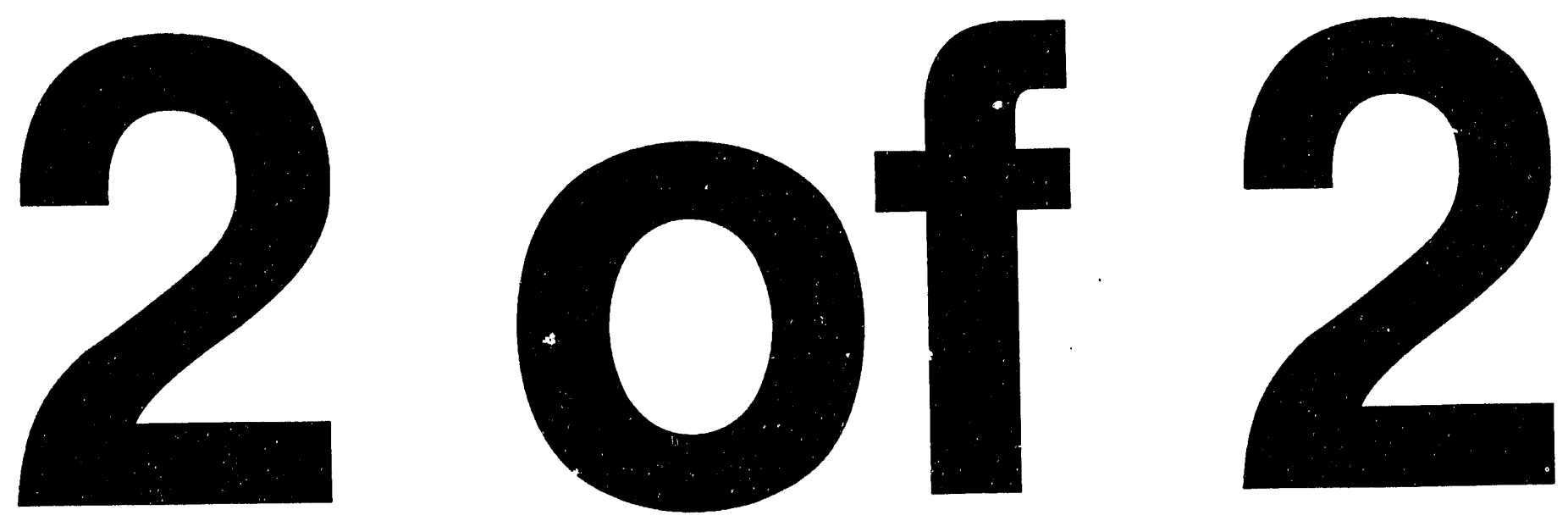


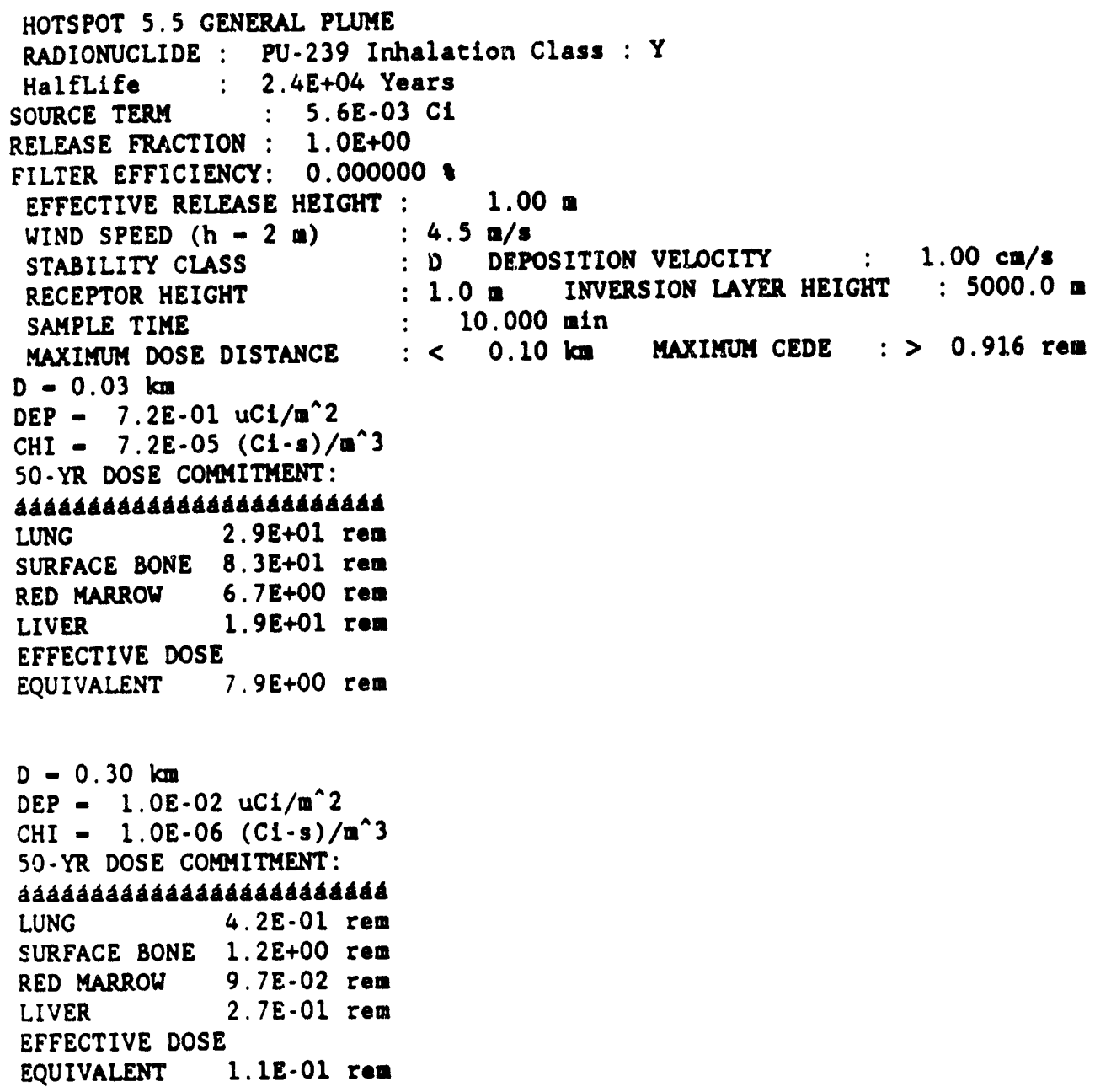


APPENDIX B

CHEMICAL DATA 
CHEMICAL DATA

\begin{tabular}{|c|c|c|c|c|c|c|c|}
\hline Chemical & Physical & Release & TLV & ERPG-3 & LOC & STEL & IDLH \\
\hline & State & Factor & $(\mathrm{mg} / \mathrm{m} 3)$ & $(\mathrm{mg} / \mathrm{m} 3)$ & (mg/m3) & $(\mathrm{mg} / \mathrm{m} 3)$ & $(\mathrm{mg} / \mathrm{m} 3)$ \\
\hline Acetaldehyde: & Liquid & 0.001 & 180 & & & 270 & 18300 \\
\hline Acetone & Liquid & 0.5 & & & & 2380 & 48000 \\
\hline Acetone cyanohydrin"* & Liquid & 0.001 & & & 12 & & \\
\hline Acetone thiosemicarbazide"* & Solid & 0.001 & & & 1000 & & \\
\hline Acetonitrile"* & Liquid & 0.001 & 67 & & & 101 & 6840 \\
\hline Acrolein & Liquid & 0.001 & & 7 & 1.1 & 0.69 & 11.7 \\
\hline Acrylamide** & Solid & 0.001 & 0.03 & & 110 & & \\
\hline Acrylonitrile** & Liquid & 0.001 & 4.3 & & 110 & & 1105 \\
\hline Acrylyl chloride** & Liquid & 0.5 & & & 0.9 & & \\
\hline Adiponitrile** & Liquid & 0.001 & & & 17 & & \\
\hline Aldicarb"* & Solid & 0.001 & & & 0.3 & & \\
\hline Aldrin"* & Solid & 0.001 & 0.25 & & 10 & & 100 \\
\hline Allyl alcohol"* & Liquid & 0.001 & 4.8 & & 36 & 9.5 & 363 \\
\hline Allyl chloride* & Liquid & 0.001 & 3 & & & 6 & 954 \\
\hline Allylamine* & Liquid & 0.5 & & & 3.2 & & \\
\hline Alkylaluminums* & Liquid & 0.001 & 2 & & & & \\
\hline Aluminun phosphide"* & Solid & 0.001 & & & 20 & & \\
\hline Aminopterin"* & Solid & 0.001 & & & 25 & & \\
\hline Amiton** & Liquid & 0.001 & & & 3.3 & & \\
\hline Amiton Oxalate"* & Solid & 0.001 & & & 3 & & \\
\hline Ammonia, anhydrous* & Gas & 1 & & 710 & 35 & 24 & 355 \\
\hline Ammonia solutions $(>44 \% \mathrm{Wt})^{*}$ & Liquid & 0.5 & 17 & & 35 & 24 & 355 \\
\hline Ammonium perchlorate* & Solid & 0.001 & & & & & \\
\hline Ammonium permanganate* & Solid & 0.001 & & & & 5 & \\
\hline Amphetamine** & Liquid & 0.001 & & & 20 & & \\
\hline Aniline** & Liquid & 0.001 & 7.6 & & 38 & & 387 \\
\hline Aniline, 2,4,6-trimethyl** & Liquid & 0.001 & & & 2.9 & & \\
\hline Antimony & Solid & 0.001 & 0.5 & & & & 80 \\
\hline Antimony pentafluoride** & Liquid & 0.001 & 0.5 & & 2.7 & & 80 \\
\hline Antimycin $A^{* *}$ & Liquid & 0.001 & & & 1.8 & & \\
\hline ANTU"* & Solid & 0.001 & 0.3 & & 10 & & 100 \\
\hline Aroclor 1254 (PCB) & Liquid & 0.001 & 0.5 & & & & 5 \\
\hline Arsenic & Solid & 0.001 & 0.01 & & 0.002 & & 100 \\
\hline Arsenic pentoxide"* & Solid & 0.001 & & & 8 & & \\
\hline Arsenous oxide** & Solid & 0.001 & & & 1.4 & & \\
\hline Arsenous trichloride** & Solid & 0.001 & & & 10 & & \\
\hline Arsin $\theta^{*}$ & Gas & 1 & & & 1.9 & & 19.4 \\
\hline Azinphos-ethyl** & Solid & 0.001 & & & 3.9 & & \\
\hline Azinphos-methy|** & Solid & 0.001 & 2 & & 0.7 & 5 & \\
\hline Barium & Solid & $0.00 !$ & 0.5 & & & & 1100 \\
\hline Benzene & Liquid & 0.001 & 32 & & 28 & & 9750 \\
\hline Benzenamine, 3-(trifluoromethyl) $)^{* *}$ & Liquid & 0.001 & & & 4.4 & & \\
\hline Benzene, 1-(chloromethyl)-4-nitro"* & Solid & 0.001 & & & 28 & & \\
\hline Benzenearsonic acid"* & Solid & 0.001 & & & 0.27 & & \\
\hline
\end{tabular}


CHEMICAL DATA

\begin{tabular}{|c|c|c|c|c|c|c|c|}
\hline Chemival & Physical & Release & TLV & ERPG-3 & LOC & STEL & IDLH \\
\hline & State & Factor & $(\mathrm{mg} / \mathrm{m} 3)$ & $(\mathrm{mg} / \mathrm{m} 3)$ & $(\mathrm{mg} / \mathrm{m} 3)$ & $(\mathrm{mg} / \mathrm{m} 3)$ & $(\mathrm{mg} / \mathrm{m} 3)$ \\
\hline Benzimidazole, 4,5-dichloro-2-(trfluoromethyl)"* & Solid & 0.001 & & & 13 & & \\
\hline Benzotrichloride"* & Liquid & 0.001 & & & 0.7 & & \\
\hline Benzyl chloride": & Liquid & 0.001 & 5.2 & & 5.2 & & 52.6 \\
\hline Benzyl cyanide*" & Liquid & 0.001 & & & 4.3 & & \\
\hline Beryllium & Solid & 0.001 & 0.002 & & & & 10 \\
\hline Bis (chloromethyl) ether BCME* & Liquid & 0.001 & 0.0047 & & 0.25 & & \\
\hline Bis (chloromethyl) ketone"* & Solid & 0.001 & 0.66 & & 0.27 & & \\
\hline Bitoscanate** & Solid & 0.001 & & & 20 & & \\
\hline Boron trichloride* & Gas & 1 & & & 10 & & \\
\hline Boron trifluöride* & Gas & 1 & & & 28 & & 282 \\
\hline Bromine* & Liquid & 0.5 & 0.66 & & 6.5 & 2 & 66.4 \\
\hline \multicolumn{8}{|l|}{ Bromine chloride* } \\
\hline Bromine pentafluoride" & Liquid & 0.5 & 0.72 & & & & \\
\hline Eromine trifluoride* & Liquid & 0.5 & & & & & 24.9 \\
\hline Bromadiolone * & Solid & 0.001 & & & & & \\
\hline Bromoform & Liquid & 0.001 & 5.2 & & & & \\
\hline \multicolumn{8}{|l|}{ Butyl hydroperoxide* } \\
\hline \multicolumn{8}{|l|}{ Butyl perbenzoate" } \\
\hline Cadmium & Solid & 0.001 & 0.005 & & & & 50 \\
\hline Cadmium oxide"* & Solid & 0.001 & 0.005 & & 4 & & 50 \\
\hline Cadmium chloride & Solid & 0.001 & 0.002 & & 0.01 & & \\
\hline Cadmium stearate"* & Solid & 0.001 & & & 1.3 & & \\
\hline Calcium arsenate"* & Solid & 0.001 & & & 10 & & \\
\hline Camphechlor"* & Solid & 0.001 & & & 20 & & \\
\hline Cantharidin"* & Solid & 0.001 & & & 4.3 & & \\
\hline Carbachol chloride"* & Solid & 0.001 & & & 15 & & \\
\hline Carbofuran"* & Solid & 0.001 & 0.1 & & 0.43 & & \\
\hline Carbon disulfide** & Liquid & 0.001 & 31 & & 160 & & 1580 \\
\hline Carbon tetrachloride & Liquid & 0.001 & 12.6 & & & & 2817 \\
\hline Carbophenothion"* & Liquid & 0.001 & & & 6.8 & & \\
\hline Chlordane*" & Liquid & 0.001 & 0.5 & & 50 & & 500 \\
\hline Chlorfenvinfos"* & Liquid & 0.001 & & & 10 & & \\
\hline Chlorine* & Gas & 1 & & 59 & 7.3 & 2.9 & 88.5 \\
\hline Chlorine dioxide* & Gas & 1 & 0.28 & & & 0.83 & 28 \\
\hline Chlorine pentrafluoride* & Gas & 1 & 2.5 & & & & \\
\hline Chlorine trifluoride* & Gas & 1 & 0.38 & & & & 77 \\
\hline Chloroacetaldehyde & Liquid & 0.001 & & & 69 & & 326 \\
\hline Chlormephos"* & Liquid & 0.001 & & & 7 & & \\
\hline Chlormequat chloride"* & Solid & 0.001 & & & 7 & & \\
\hline Chloroacetic acid** & Solid & 0.001 & & & 1.8 & & \\
\hline Chlorobenzene & Liquid & 0.001 & 46 & & & & 11232 \\
\hline Chlorodiethylaluminum ${ }^{*}$ & Liquid & 0.001 & 2 & & & & \\
\hline 1-Chloro-2,4-dinitrobenzene* & Solid & 0.001 & & & & & \\
\hline Chloroethanol** & Liquid & 0.001 & & & 3.3 & & \\
\hline
\end{tabular}




\begin{tabular}{|c|c|c|c|c|c|c|c|}
\hline Chemical & Physical & Release & TLV & ERPG-3 & LOC & STEL & IDLH \\
\hline & State & Factor & $(\mathrm{mg} / \mathrm{m} 3)$ & $(\mathrm{mg} / \mathrm{m} 3)$ & $(\mathrm{mg} / \mathrm{m} 3)$ & $(\mathrm{mg} / \mathrm{m} 3)$ & $(\mathrm{mg} / \mathrm{m} 3)$ \\
\hline Chloroethyl chloroformate"* & Liquid & 0.001 & & & 20 & & \\
\hline Chloroform"* & Liquid & 0.001 & 9.78 & & & & 4960 \\
\hline Chloromethane & Gas & 1 & 1030 & & & & \\
\hline Chloromethyl ether"* & Liquid & 0.001 & 0.005 & & 0.25 & & \\
\hline Chloromethyl methyl ether* & Liquid & 0.001 & & & 1.8 & 3.35 & \\
\hline Chlorophacione** & Solid & 0.001 & & & 1 & & \\
\hline Chloropicrin* & Liquid & 0.001 & 0.67 & 20.5 & & & 27.3 \\
\hline Chloropicrin \& Methyl bromide" & Liquid & 0.001 & & & & & \\
\hline Chloropicrin \& Methyl chloride* & Liquid & 0.001 & & & & & \\
\hline Chloroxuron"* & Solid & 0.001 & & & 10 & & \\
\hline Chlorothiophos"* & Liquid & 0.001 & & & 7.8 & & \\
\hline Chromic chloride"* & Solid & 0.001 & & & 0.05 & & \\
\hline Chromium & Solid & 0.001 & 0.5 & & & & \\
\hline Cobalt & Solid & 0.001 & 0.05 & & 2 & & 20 \\
\hline Cobalt carbony|** & Solid & 0.001 & 0.1 & & 0.27 & & \\
\hline Colchicine** & Solid & 0.001 & & & 0.9 & & \\
\hline Copper & Solid & 0.001 & 1 & & & & \\
\hline Coumaphos"* & Solid & 0.001 & & & 3 & & \\
\hline Coumatetraly|"** & Solid & 0.001 & & & 16.5 & & \\
\hline Cresol, o.** & Solid & 0.001 & 22 & & 110 & & 1125 \\
\hline Crimidine"* & Solid & 0.001 & & & 1.2 & & \\
\hline Crotonaldehyde** & Liquid & 0.001 & & 145.5 & 40 & & 1164 \\
\hline Cumene hydroperoxide & Liquid & 0.001 & & & & & \\
\hline Cyanide & Gas & 1 & 5 & & & & 50 \\
\hline Cyanogen" & Liquid & 0.001 & 21 & & & & \\
\hline Cyanogen bromide"* & Solid & 0.001 & & & 44 & & \\
\hline Cyanogen chloride* & Gas & 1 & & & & 0.75 & \\
\hline Cyanuri-fluoride* & Liquid & 0.001 & 2.5 & & & & \\
\hline Cyanogen iodide** & Solid & 0.001 & & & 180 & & \\
\hline Cyanophos** & Liquid & 0.001 & & & 25 & & \\
\hline Cyanuric fluoride** & Liquid & c.001 & & & 0.17 & & \\
\hline Cyclohexane & Liquid & 0.001 & 100 & & & & 35000 \\
\hline Cycloheximide"* & Solid & 0.001 & & & 2 & & \\
\hline Cyclohexylamine"* & Liquid & 0.01 & 41 & & 160 & & \\
\hline Cyclopentane & Liquid & 0.5 & 1720 & & 110 & & \\
\hline Decaborane*" & Solid & 0.001 & 0.25 & & 10 & 0.75 & 100 \\
\hline Demeton** & Liquid & 0.001 & 0.11 & & 2 & & 20 \\
\hline Demeton-S-methyl"* & Liquid & 0.001 & & & 5 & & \\
\hline Diacetyl peroxide" & Liquid & 0.001 & & & & & \\
\hline Dialifor** & Solid & 0.001 & & & 5 & & \\
\hline Diazomethane* & Gas & 1 & 0.34 & & & & 35 \\
\hline Dibenzoyl peroxide" & Solid & 0.001 & 5 & & & & \\
\hline Diborane* & Gas & 1 & & & 5 & & 46 \\
\hline Dibutyl peroxide" & & & & & & & \\
\hline
\end{tabular}




\begin{tabular}{|c|c|c|c|c|c|c|c|}
\hline Chemical & Physical & Release & TLV & ERPG-3 & LOC & STEL & IDLH \\
\hline & State & \begin{tabular}{|l|} 
Factor \\
\end{tabular} & $(\mathrm{mg} / \mathrm{m} 3)$ & $(\mathrm{mg} / \mathrm{m} 3)$ & $(\mathrm{mg} / \mathrm{m} 3)$ & $(\mathrm{mg} / \mathrm{m} 3)$ & $(\mathrm{mg} / \mathrm{m} 3)$ \\
\hline Dichloro Acetylene* & Liquid & 0.001 & & & & 0.39 & \\
\hline 1,2-Dichlorobenzene & Liquid & 0.001 & 301 & & & 675 & 6110 \\
\hline 1,1-Dichloroethane & Liquid & 0.001 & 400 & & & 1010 & 16,480 \\
\hline 1,2-Dichloroethane & Liquid & 0.001 & 4 & & & 8 & 4110 \\
\hline 1,1-Dichloroethylene & Liquid & 0.001 & 20 & & & 79 & \\
\hline 1,2-Dichloroethylene & Liquid & 0.001 & 790 & & & & 16120 \\
\hline 1,2-Dichloropropane & Liquid & 0.001 & 347 & & & 508 & 9400 \\
\hline Cis 1,3-Dichloropropene & Liquid & 0.001 & 4.5 & & & & \\
\hline Trans 1,3-Dichloropropene & Liquid & 0.001 & 4.5 & & & & \\
\hline Dichloroethyl ether & Liquid & 0.001 & 29 & & 150 & 58 & 1485 \\
\hline Dichloromethylphenylsilane** & Liquid & 0.001 & & & 20 & & \\
\hline \multicolumn{8}{|l|}{ Dichlorosilane $\theta^{*}$} \\
\hline Dichlorvos & Liquid & 0.001 & 0.9 & & 20 & & 200 \\
\hline Dicrotophos & Liquid & 0.001 & 0.25 & & 0.9 & & \\
\hline Diepoxybutane"* & Liquid & 0.001 & & & 3.5 & & \\
\hline Diethyl chlorophosphate"* & Liquid & 0.001 & & & 8 & & \\
\hline Diethylcarbamazine citrate" & Solid & 0.001 & & & 3 & & \\
\hline Diethylzinc* & Liquid & 0.001 & & & & & \\
\hline Digitoxin"* & Solid & 0.001 & & & 0.18 & & \\
\hline Diglycidyl ether"* & Liquid & 0.001 & 0.53 & & 45 & & 135.3 \\
\hline Digoxin"* & Solid & 0.001 & & & 0.2 & & \\
\hline \multicolumn{8}{|l|}{ Diisopropyl peroxydicarbonate } \\
\hline Diketene & Liquid & 0.001 & & 175 & & & \\
\hline \multicolumn{8}{|l|}{ Dilaluroyl peroxide" } \\
\hline Dimefox** & Liquid & 0.001 & & & 1 & & \\
\hline Dimethoate"* & Solid & 0.001 & & & 30 & & \\
\hline Dimethylamine, anhydrous" & Gas & 1 & 9.2 & 920 & & 27.6 & 3740 \\
\hline Dimethyldichlorosilane* & Liquid & 0.001 & & & & & \\
\hline Dimethylhydrazine, $1,1-^{*}$ & Liquid & 0.01 & 1.2 & & 12 & & 125 \\
\hline Dimethyl phosphorochloridothioate** & Liquid & 0.001 & & & 3.2 & & \\
\hline Dimethyl sulfate** & Liquid & 0.001 & 0.52 & & 5 & & 52.4 \\
\hline Dimethyldichlorosilane** & Liquid & 0.01 & & & 3 & & \\
\hline Dimethyl-p-phenylenediamine ** & Solid & 0.001 & & & 0.13 & & \\
\hline Dimetilian"* & Solid & 0.001 & & & 25 & & \\
\hline 2,4-Dinitroaniline* & Solid & 0.001 & & & & & \\
\hline Dinitrocresol"* & Solid & 0.001 & 0.2 & & 0.5 & & 5 \\
\hline Dinoseb"* & Solid & 0.001 & & & 4.5 & & \\
\hline Dinoterb": & Solid & 0.001 & & & 25 & & \\
\hline Dioxathion": & Liquid & 0.001 & 0.2 & & 3.4 & & \\
\hline Diphacinone*" & Solid & 0.001 & & & 0.9 & & \\
\hline Disphosphoramide, octamethyl"* & Liquid & 0.001 & & & 0.8 & & \\
\hline Disulfoton"* & Liquid & 0.001 & 0.1 & & 2 & & \\
\hline Dithiazanine iodide*" & Solid & 0.001 & & & 20 & & \\
\hline Dithiobiuret** & Solid & 0.001 & & & 5 & & \\
\hline
\end{tabular}




\begin{tabular}{|c|c|c|c|c|c|c|c|}
\hline Chemical & Physical & Release & TLV & ERPG-3 & LOC & STEL & IDLH \\
\hline & State & Factor & $(\mathrm{mg} / \mathrm{m} 3)$ & $(\mathrm{mg} / \mathrm{m} 3)$ & $(\mathrm{mg} / \mathrm{m3})$ & $(\mathrm{mg} / \mathrm{m} 3)$ & $(\mathrm{mg} / \mathrm{m} 3)$ \\
\hline Emetine, dihydrochloride"- & Solid & 0.001 & & & 0.01 & & \\
\hline Endosulfan"* & Solid & 0.001 & 0.1 & & 0.8 & & \\
\hline Endothion"* & Solid & 0.001 & & & 17 & & \\
\hline Endrin"* & Solid & 0.001 & 0.1 & & 20 & & 2000 \\
\hline Epichlorohydrin"* & Liquid & 0.001 & 7.6 & & 38 & & 962 \\
\hline EPN"* & Solid & 0.001 & 0.5 & & 5 & & 50 \\
\hline Ergocalciferol** & Solid & 0.001 & & & 40 & & \\
\hline Ergotamine tartrate"* & Solid & 0.001 & & & 10 & & \\
\hline Ethanesulfonyl chloride, 2-chloro"* & Liquid & 0.001 & & & 25 & & \\
\hline Ethanol, 1,2-dichloro-, acetate"* & Liquid & 0.001 & & & 11 & & \\
\hline Ethion"* & Liquid & 0.001 & 0.4 & & 13 & & \\
\hline Ethoprophos": & Liquid & 0.001 & & & 26 & & \\
\hline Ethylbenzene & Liquid & 0.001 & 434 & & & 543 & 8820 \\
\hline Ethylbis (2-chloroethyl) amine** & Liquid & 0.001 & & & 7.5 & & \\
\hline Ethyl other & Liquid & 0.001 & 1210 & & & 1520 & \\
\hline Ethylene fluorohydrin"* & Liquid & 0.001 & & & 0.07 & & \\
\hline Ethyl nitrate & Liquid & 0.001 & & & & & \\
\hline Ethylamine $\theta^{*}$ & Gas & 1 & 18 & & & & 7840 \\
\hline Ethylene dichloride & Liquid & 0.001 & 40 & & 8 & & 4110 \\
\hline Ethylene fluorohydrin & Liquid & 0.001 & & & & & \\
\hline Ethylene oxide" & Gas & 0.01 & 1.8 & & 140 & & 1464 \\
\hline Ethylenediamine** & Liquid & 0.001 & 25 & & 490 & & 5000 \\
\hline Ethyleneimine" & Liquid & 0.001 & 0.88 & & 4 & & 179 \\
\hline Ethylthiocyanate"* & Liquid & 0.001 & & & 0.2 & & \\
\hline Fenamiphos"* & Solid & 0.001 & 0.1 & & 0.9 & & \\
\hline Fenitrothion"* & Liquid & 0.001 & & & 3.8 & & \\
\hline Fensulfothion"* & Liquid & 0.001 & 0.1 & & 2 & & \\
\hline Fluenetil"* & Solid & 0.001 & & & 6 & & \\
\hline Fluorine* & Gas & 1 & & & 39 & 3.1 & 142.8 \\
\hline Fluoroacetamide": & Solid & 0.001 & & & 5.8 & & \\
\hline Fluoroacetic acid"* & Solid & 0.001 & & & 0.47 & & \\
\hline Fluoroacetyl chloride"* & Liquid & 0.001 & & & 10 & & \\
\hline Fluorouracil"* & Solid & 0.001 & & & 19 & & \\
\hline Fonotos"* & Liquid & 0.001 & 0.1 & & 1.3 & & \\
\hline Formaldehyde* & Gas & 1 & 0.3 & 30.67 & 12 & & 36.7 \\
\hline Formaldehyde* & Liquid & 0.001 & 0.3 & & 12 & 2.5 & 36.7 \\
\hline Formaldehyde cyanohydrin"* & Liquid & 0.001 & & & 6 & & \\
\hline Formetanate hydrochloride"* & Solid & 0.001 & & & 18 & & \\
\hline Formic acid & Liquid & 0.001 & 9.4 & & 19 & & 57.3 \\
\hline Formothion"* & Liquid & 0.001 & & & 0.27 & & \\
\hline Formparanate "* & Solid & 0.001 & & & 7.2 & & \\
\hline Fosthietan"* & Liquid & 0.001 & & & 4.7 & & \\
\hline Freon 113 & Liquid & 0.001 & 7600 & & & 9500 & 35055 \\
\hline Fuberidazole"* & Solid & 0.001 & & & 3.3 & & \\
\hline
\end{tabular}




\begin{tabular}{|c|c|c|c|c|c|c|c|}
\hline Chemical & Physical & Release & TLV & ERPG-3 & LOC & STEL & IDLH \\
\hline & State & Factor & $(\mathrm{mg} / \mathrm{m} 3)$ & $(\mathrm{mg} / \mathrm{m} 3)$ & $(\mathrm{mg} / \mathrm{m} 3)$ & $(\mathrm{mg} / \mathrm{m} 3)$ & $(\mathrm{mg} / \mathrm{m} 3)$ \\
\hline Furan* & Liquid & 0.001 & & & 1.2 & & \\
\hline Gallium trichloride** & Solid & 0.001 & & & 32 & & \\
\hline Hexachlorobutadiene & Liquid & 0.001 & 0.21 & 315 & & & \\
\hline Hexachlorocyclopentadiene** & Liquid & 0.001 & 0.11 & & 0.2 & & \\
\hline Hexamethylenediamin $\theta, N_{1} N^{\prime}$-dibutyl|* & Liquid & 0.001 & & & 2.2 & & \\
\hline Hexachloronapthalene & Solid & 0.001 & 0.2 & & 0.2 & & 2 \\
\hline Hexafluoracetone* & Gas & 1 & 0.68 & & & & \\
\hline Hydrochloric acid, Anhydrous" & Liquid & 0.001 & & & & 7.5 & 152 \\
\hline Hydrofluoric acid, Anhydrous* & Liquid & 0.001 & 2.5 & & & 5 & 25 \\
\hline Hydrazine"* & Liquid & 0.001 & 0.13 & & 10 & & 106.4 \\
\hline Hydrocyanic acid"* & Gas & 1 & & & 5.5 & & \\
\hline Hydrogen bromide & Gas & 1 & & & & 10 & 168 \\
\hline Hydrogen chloride* & Gas & 1 & & 150 & 15 & & 152 \\
\hline Hydrogen cyanide, Anhydrous" & Liquid & 0.5 & & & & 5 & 56 \\
\hline Hydrogen fluoride* & Gas & 1 & & 43.3 & 1.6 & & 24.9 \\
\hline Hydrogen peroxide (Conc $>52 \%)^{*}$ & Liquid & 0.001 & 1.4 & & 10 & & 105.8 \\
\hline Hydrogen selenide" & Gas & 1 & 0.16 & & 0.66 & & 6.7 \\
\hline Hydrogen sulfide" & Gas & 1 & 14 & & 42 & 21 & 426 \\
\hline Hydroquinone"* & Solid & 0.001 & 2 & & 20 & & \\
\hline Hydroxylamine* & Solid & 0.001 & & & & & \\
\hline Iron pentacarbonyl" & Liquid & 0.001 & 0.23 & & 0.8 & 0.45 & \\
\hline Isobenzan"* & Solid & 0.001 & & & 1 & & \\
\hline Isobutyl nitrile** & Liquid & 0.001 & & & 25 & & \\
\hline Isocyanic acid, 3,4-dichlorphenyl ester" & Solid & 0.001 & & & 14 & & \\
\hline Isodrin"* & Solid & 0.001 & & & 7 & & \\
\hline Isofluorphate"* & Liquid & 0.001 & & & 3.6 & & \\
\hline Isophorone diisocyanate"* & Solid & 0.001 & 0.045 & & 1.23 & & \\
\hline Isopropyl chloroformate"* & Liquid & 0.001 & & & 100 & & \\
\hline Isoproplymethylpyrazolyl dimethylcarbamate"* & Liquid & 0.001 & & & 5.6 & & \\
\hline Isopropylamine* & Liquid & 0.001 & 12 & & & 24 & 9840 \\
\hline Ketene & Gas & 1 & 0.86 & & & 2.6 & \\
\hline Lactonitrile"* & Liquid & 0.001 & & & 18 & & \\
\hline Lead & Solid & 0.001 & 0.05 & & & & \\
\hline Leptophos** & Solid & 0.001 & & & 30 & & \\
\hline Lewisite"* & Liquid & 0.001 & & & 4.7 & & \\
\hline Lindane** & Solid & 0.001 & 0.5 & & 100 & & 1000 \\
\hline Lithium hydride"* & Solid & 0.001 & 0.025 & & 5 & & 55 \\
\hline Malonitrile"* & Solid & 0.001 & & & 19 & & \\
\hline Manganese & Solid & 0.001 & 1 & & & 3 & \\
\hline Manganese, tricarbonyl methycyclopentadieny| ${ }^{* *}$ & Liquid & 0.001 & 1 & & 0.6 & 3 & \\
\hline Mechlorethamine** & Liquid & 0.001 & & & 29 & & \\
\hline Mephosfolan"* & Liquid & 0.001 & & & 9 & & \\
\hline Mercuric acetate"* & Solid & 0.001 & 0.01 & & 24 & & \\
\hline Mercuric chloride*" & Solid & 0.001 & & & 30 & & \\
\hline
\end{tabular}




\begin{tabular}{|c|c|c|c|c|c|c|c|}
\hline Chemical & Physical & Release & TLV & ERPG-3 & LOC & STEL & IDLH \\
\hline & State & Factor & $(\mathrm{mg} / \mathrm{m} 3)$ & $(\mathrm{mg} / \mathrm{m} 3)$ & $(\mathrm{mg} / \mathrm{m} 3)$ & $(\mathrm{mg} / \mathrm{m} 3)$ & $(\mathrm{mg} / \mathrm{m} 3)$ \\
\hline Mercuric oxide"* & Solid & 0.001 & & & 16 & & \\
\hline Mercurous nitrate & Solid & 0.001 & 0.05 & & 0.1 & & \\
\hline Mercury alkyl compounds & Solid & 0.001 & 0.01 & & 30 & 0.03 & \\
\hline Mercury oxycyanide & Solid & 0.001 & 0.01 & & & & \\
\hline Mercury vapor & Liquid & 0.01 & & & & & 28 \\
\hline Methacrolein diacetate"* & Liquid & 0.001 & & & 44 & & \\
\hline Methacrylic anhydride": & Liquid & 0.001 & & & 4.5 & & \\
\hline Methacrylaldehyde* & Liquid & 0.001 & & & & & 358 \\
\hline Methacrylonitrile"* & Liquid & 0.001 & & & 3 & & \\
\hline Methacryloyl chloride" & Liquid & 0.001 & & & 0.6 & & \\
\hline Methacryloyloxyethyl isocyanate* & Liquid & 0.001 & & & 0.27 & & \\
\hline Mathamidophos"* & Solid & 0.001 & & & 7.5 & & \\
\hline Methanesulfonyl fluoride"* & Liquid & 0.001 & & & 14 & & \\
\hline Methyl acrylonitrile* & Liquid & 0.001 & 2.7 & & & & \\
\hline Methanol & Liquid & 0.001 & 262 & & & 328 & 33250 \\
\hline Methidathion ** & Solid & 0.001 & & & 20 & & \\
\hline Methiocarb"* & Solid & 0.001 & & & 15 & & \\
\hline Methomy|** & Solid & 0.001 & 2.5 & & 10 & & \\
\hline Methoxyethyimercuric acetate"* & Solid & 0.001 & & & 25 & & \\
\hline Methyl 2-chloroacrylate"* & Liquid & 0.001 & & & 5 & & \\
\hline Methylamine, anhydrous" & Gas & 1 & 6.4 & & & 19 & 129 \\
\hline Methyl bromide" & Gas & 1 & 19 & & 780 & & 7900 \\
\hline Methyl chloride* & Gas & 1 & 103 & & & 207 & 21000 \\
\hline Methyl chloroformate* & Liquid & 0.001 & & & 1.8 & & \\
\hline Methyl disulfide & Liquid & 0.001 & & & 0.1 & & \\
\hline Methyl isothiocyanate"* & Solid & 0.001 & & & & & \\
\hline Methyl ethyl ketone & Liquid & 0.001 & 590 & & & 885 & 9000 \\
\hline Methyl ethyl ketone peroxide & Liquid & 0.001 & & & & 1.5 & \\
\hline Methyl fluoracetate* & Liquid & 0.001 & & & & & \\
\hline \multicolumn{8}{|l|}{ Methyl fluorosulfate" } \\
\hline Methyl hydrazine* & Liquid & 0.001 & 0.38 & & 0.94 & & 96 \\
\hline Methyl iodide* & Liquid & 0.001 & 10 & & & & \\
\hline Methyl isocyanate* & Liquid & 0.5 & 0.047 & & 4.7 & & 47.4 \\
\hline Methyl mercaptan" & Gas & 1 & 0.98 & 196 & 79 & & 800 \\
\hline Methyl phenkapton"* & Liquid & 0.001 & & & 11 & & \\
\hline Methyl phosphonic dichloride"* & Solid & 0.001 & & & 1.4 & & \\
\hline Methyl thiocyanate"* & Liquid & 0.001 & & & 85 & & \\
\hline Methyl vinyl ketone" & Liquid & 0.01 & & & 0.07 & & \\
\hline Methylene chloride & Liquid & 0.5 & 174 & & 3530 & & 17650 \\
\hline Methylitrichlorosilane" & Liquid & 0.001 & & & 1.8 & & \\
\hline Methyimercuric dicyanamide"* & Solid & 0.001 & & & 20 & & \\
\hline Methytrichlorosilane"* & Liquid & 0.001 & & & 1.8 & & \\
\hline Metolcarb"* & Solid & 0.001 & & & 4.8 & & \\
\hline Movinphos"* & Liquid & 0.001 & & & 4 & & \\
\hline
\end{tabular}




\begin{tabular}{|c|c|c|c|c|c|c|c|}
\hline Chemical & Physical & Release & $T L V$ & ERPG-3 & LOC & STEL & IDLH \\
\hline & State & Factor & $(\mathrm{mg} / \mathrm{m} 3)$ & $(\mathrm{mg} / \mathrm{m} 3)$ & $(\mathrm{mg} / \mathrm{m} 3)$ & $(\mathrm{mg} / \mathrm{m} 3)$ & $(\mathrm{mg} / \mathrm{m} 3)$ \\
\hline Mexacarbate"* & Solid & 0.001 & & & 14 & & \\
\hline Mitomycin C"* & Solid & 0.001 & & & 23 & & \\
\hline Molybdenum & Solid & 0.001 & 10 & & & & \\
\hline Monocrotophos": & Solid & 0.001 & 0.25 & & 0.63 & & \\
\hline Muscimol"* & Solid & 0.001 & & & 17 & & \\
\hline Mustard Gas": & Liquid & 0.001 & & & 1 & & \\
\hline Naphthalene & Solid & 0.001 & 50 & & & 75 & 2500 \\
\hline Nickel & Solid & 0.001 & & & 50 & & \\
\hline Nickel carbonyl* & Liquid & 0.5 & 0.12 & & 0.35 & & 49.7 \\
\hline Nicotine"* & Liquid & 0.001 & 0.5 & & 3.5 & & 35 \\
\hline Nicotine sulfate"* & Solid & 0.001 & & & 9 & & \\
\hline Nitric acid* & Liquid & 0.001 & 5.2 & & 26 & 10 & 262 \\
\hline Nitric oxide" & Gas & 1 & & & 30 & & 125 \\
\hline Nitroaniline* & Solid & 0.001 & 3 & & & & 300 \\
\hline Nitrobenzene** & Liquid & 0.001 & 5 & & 100 & & 1024 \\
\hline Nitrocyclohexan $\theta^{* *}$ & Liquid & 0.001 & & & 1.5 & & \\
\hline Nitromethane" & Liquid & 0.001 & 250 & & & & 2540 \\
\hline Nitrogen dioxide & Liq/Gas & 1 & 5.6 & & 9.4 & 9.4 & 95.5 \\
\hline Nitrogen oxides (NO, N2O4, N2O3)" & Gas & 1 & 30 & & & & 125 \\
\hline Nitrogen trifluoride ${ }^{*}$ & Gas & 1 & 29 & & 29 & & 5900 \\
\hline Nitropropane-2 & Liquid & 0.001 & 36 & & & & 8510 \\
\hline Nitrosodimethylamine*" & Liquid & 0.001 & & & 19 & & \\
\hline Norbormide"* & Solid & 0.001 & & & 3.8 & & \\
\hline Oloum* & Liquid & 0.001 & 1 & & 8 & 3 & 80 \\
\hline Osmium tetroxide $\theta^{*}$ & Solid & 0.001 & 1.6 & & 0.1 & 0.0047 & 1 \\
\hline Ouabain"* & Solid & 0.001 & & & 8.3 & & \\
\hline Oxamyl & Solid & 0.001 & & & 1.7 & & \\
\hline Oxetane, 3,3-bis (chloromethyl)"* & Liquid & 0.001 & & & 2 & & \\
\hline Oxydisulfoton ${ }^{* *}$ & Liquid & 0.001 & & & 3.5 & & \\
\hline Oxygen difluoride* & Gas & 1 & 0.11 & & & & 1.12 \\
\hline Ozone* & Gas & 1 & 0.22 & & 2 & 0.6 & 20 \\
\hline P-dichlorobenzene & Solid & 0.001 & 451 & & & 661 & 6000 \\
\hline Paraquat"* & Solid & 0.001 & 0.1 & & 0.15 & & 1.5 \\
\hline Paraquat methosulfate*" & Solid & 0.001 & & & 0.5 & & \\
\hline Parathion"* & Liquid & 0.001 & 0.1 & & 2 & & 20 \\
\hline Parathion methyl"* & Solid & 0.001 & & & 0.34 & & \\
\hline Paris Green"* & Solid & 0.001 & & & 22 & & \\
\hline Pentaborane & Liquid & 0.01 & 0.013 & & 0.8 & 0.039 & 7.9 \\
\hline Pentadecylamine"* & Solid & 0.001 & & & 2 & & \\
\hline Peracetic acid" & Liquid & 0.001 & & & 4.5 & & \\
\hline Perchloric acid" & Liquid & 0.001 & & & & & \\
\hline Perchloromethyl mercaptan ${ }^{\circ}$ & Liquid & 0.001 & 0.76 & & 7.6 & & 77.3 \\
\hline Perchloryl fluoride" & Gas & 1 & 13 & & & 25 & 1582 \\
\hline Perfluoroisobutylene & Gas & 1 & & 2.46 & & & \\
\hline
\end{tabular}




\begin{tabular}{|c|c|c|c|c|c|c|c|}
\hline Chemical & Physical & Release & TLV & ERPG-3 & LOC & STEL & IDLH \\
\hline & State & Factor & $(\mathrm{mg} / \mathrm{m} 3)$ & $(\mathrm{mg} / \mathrm{m} 3)$ & $(\mathrm{mg} / \mathrm{m} 3)$ & $(\mathrm{mg} / \mathrm{m3})$ & $(\mathrm{mg} / \mathrm{m} 3)$ \\
\hline Peroxyacetic acid* & Liquid & 0.001 & & & 4.5 & & \\
\hline Phenol** & Solid & 0.001 & 19 & & 39 & & 960 \\
\hline Phenol, 2,2'-thiobis (4-chloro-6-methyl)"* & Solid & 0.001 & & & 1.3 & & \\
\hline Phenol, 3- (1-methylethyl)-, methylcarbarnate"* & Solid & 0.001 & & & 16 & & \\
\hline Phenoxarsine, $10,10^{\prime}$-oxydi** & Solid & 0.001 & & & 14 & & \\
\hline Phenyl dichloroarsine"* & Liquid & 0.001 & & & 4 & & \\
\hline Phenylhydrazine hydrochloride"* & Solid & 0.001 & & & 250 & & \\
\hline Phenylmercury acetate"* & Solid & 0.001 & & & 22 & & \\
\hline Phenylsilitrane"* & Solid & 0.001 & & & 1 & & \\
\hline Phenylthiourma** & Solid & 0.001 & & & 3 & & \\
\hline Phorate"* & Liquid & 0.001 & 0.05 & & 0.1 & 0.2 & \\
\hline Phosacetim"* & Solid & 0.001 & & & 3.7 & & \\
\hline Phosfolan"* & Solid & 0.001 & & & 9 & & \\
\hline Phosgent" & Gas & 1 & 0.4 & 4 & 0.8 & & 8.2 \\
\hline Phosmet"* & Solid & 0.001 & & & 0.54 & & \\
\hline Phosphamidon "* & Liquid & 0.001 & & & 0.3 & & \\
\hline Phosphine" & Gas & 1 & & & 28 & 1.4 & 282 \\
\hline Phosphoric acid & Liquid & 0.001 & 1 & & & 3 & 10000 \\
\hline Phosphorus"* & Solid & 0.5 & 0.1 & & 3 & & \\
\hline Phosphorus oxychloride" & Liquid & 0.001 & 0.63 & & 3 & & \\
\hline Phosphorus pentachloride & Solid & 0.001 & 0.85 & & 20 & & 200 \\
\hline Phosphorus pentoxide"* & Solid & 0.001 & & 100 & 0.6 & & \\
\hline Phosphorus trichloride* & Liquid & 0.01 & 1.1 & & 28 & 2.8 & 285.5 \\
\hline Phosphoryl chloride* & Liquid & 0.001 & 0.6 & & & & \\
\hline Physostigmine** & Solid & 0.001 & & & 4.5 & & \\
\hline Physostigmine, salicylate $(1: 1)^{* *}$ & Solid & 0.001 & & & 2.5 & & \\
\hline Picrotoxin** & Solid & 0.001 & & & 15 & & \\
\hline Piperidine*" & Liquid & 0.001 & & & 22 & & \\
\hline Platinum (sol. cpds.) & Solid & 0.001 & & & & & \\
\hline Platinum metal & Solid & 0.001 & & & & & \\
\hline Potassium arsenite"* & Solid & 0.001 & & & 14 & & \\
\hline Potassium cyanide** & Solid & 0.001 & & & 5 & & \\
\hline Potassium silver cyanide"* & Solid & 0.001 & & & 20 & & \\
\hline Promecarb"* & Solid & 0.001 & & & 16 & & \\
\hline Propargyl bromide* & Liquid & 0.001 & & & 0.03 & & \\
\hline Propiolactone-beta"* & Liquid & 0.001 & 1.5 & & 1.5 & & \\
\hline Propionitrile"* & Liquid & 0.001 & & & 3.7 & & \\
\hline Propionitrile, 3-chloro"* & Liquid & 0.001 & & & 9 & & \\
\hline Propiophenone, 4-amino"* & Solid & 0.001 & & & 5.6 & & \\
\hline Propyl chloroformate"* & Liquid & 0.001 & & & 10 & & \\
\hline Propyl nitrate* & Liquid & 0.001 & 107 & & & 172 & 8740 \\
\hline Propyleneimine"* & Liquid & 0.001 & 4.7 & & 120 & & 1185 \\
\hline Propylene oxide*" & Liquid & 0.5 & 48 & & 480 & & 4840 \\
\hline Prothoate"* & Solid & 0.001 & & & 1.7 & & \\
\hline
\end{tabular}




\begin{tabular}{|c|c|c|c|c|c|c|c|}
\hline Chemical & Physical & Release & TLV & ERPG-3 & LOC & STEL & IOLH \\
\hline & State & Factor & $(\mathrm{mg} / \mathrm{m} 3)$ & $(\mathrm{mg} / \mathrm{m} 3)$ & $(\mathrm{mg} / \mathrm{m} 3)$ & $(\mathrm{mg} / \mathrm{m} 3)$ & $(\mathrm{mg} / \mathrm{m} 3)$ \\
\hline Pyrene"* & Solid & 0.001 & & & 1.7 & & \\
\hline Pyridine, 2-methyl-5-vinyl"* & Liquid & 0.001 & & & 1.9 & & \\
\hline Pyridine, 4-amino"* & Solid & 0.001 & & & 20 & & \\
\hline Pyridine, 4-nitro, 1-oxide"* & Solid & 0.001 & & & 80 & & \\
\hline Pyriminil** & Solid & 0.001 & & & 6.2 & & \\
\hline Salcomine"* & Solid & 0.001 & & & 39 & & \\
\hline Sarin" & Liquid & 0.001 & & & 0.05 & & \\
\hline Selenious acid"* & Solid & 0.001 & & & 250 & & \\
\hline Selenium hexafluoride & Gas & 1 & 0.16 & & & & 40 \\
\hline Selenium oxychloride"* & Liquid & 0.001 & & & 10 & & \\
\hline Semicarbazide hydrochlorids"* & Solid & 0.001 & & & 100 & & \\
\hline Silane, (4-aminobutyl) diethoxymethy $\left.\right|^{* *}$ & Liquid & 0.001 & & & 45 & & \\
\hline Silver, metal & Solid & 0.001 & 0.1 & & & & \\
\hline Silver, soluble compounds & Solid & 0.001 & 0.01 & & & & \\
\hline Sodium arsenate"* & Solid & 0.001 & & & 130 & & \\
\hline Sodium : rssenite"* & Solid & 0.001 & & & 10 & & \\
\hline Sodium azide"* & Solid & 0.001 & & & 20 & 0.29 & \\
\hline Sodium cacodylates": & Solid & 0.001 & & & 4 & & \\
\hline Sodium cyanide"* & Solid & 0.001 & & & 5 & & \\
\hline Sodium fluoroactate *" & Solid & 0.001 & 0.05 & & 0.5 & 0.15 & 5 \\
\hline Sodium hydroxide & Liquid & 0.001 & 2 & & & & 250 \\
\hline Sodium selenate*" & Solid & 0.001 & & & 1.6 & & \\
\hline Sodium selenite** & Solid & 0.001 & & & 2.3 & & \\
\hline Sodium tellurite"* & Solid & 0.001 & & & 20 & & \\
\hline Stannane, acetoxytriphenyl|* & Solid & 0.001 & & & 20 & & \\
\hline Stibine* & Gas & 1 & 0.51 & & & & 207 \\
\hline Styrene & Liquid & 0.001 & 215 & & & 425 & 21650 \\
\hline Strychnine** & Solid & 0.001 & 0.15 & & 0.3 & & 3 \\
\hline Strychnine sulfate". & Solid & 0.001 & & & 5 & & \\
\hline Sulfotep"* & Liquid & 0.001 & 0.2 & & 3.5 & & \\
\hline Sulfoxide, 3-chloropropyl octyl** & Liquid & 0.001 & & & 8 & & \\
\hline Sulfur dioxide* & Gas & 1 & & 39 & 26 & 13 & 266 \\
\hline Sulfur pentafluoride" & Gas & 1 & & & & 0.1 & 10.6 \\
\hline Sulfur tetrafluoride" & Gas & 1 & & & 9.2 & 0.44 & \\
\hline Sulfur trioxide* & Solid & 0.5 & & & 3 & & \\
\hline Sulfuric acid"* & Liquid & 0.001 & 1 & 30 & 8 & 3 & 80 \\
\hline Sulfuric anhydride" & Solid & 0.001 & & & & & \\
\hline Tabun"* & Liquid & 0.001 & & & 0.15 & & \\
\hline Tollurium"* & Solid & 0.001 & 0.1 & & 20 & & \\
\hline Tellurium hexafluoride" & Gas & 1 & 0.2 & & 1 & & 10 \\
\hline 1,1,2,2-Tetrachloroethane & Liquid & 0.001 & 7 & & & & 1050 \\
\hline Tetrachloroethylene (Perchloroethylene) & Liquid & 0.001 & 170 & & & 1357 & 3445 \\
\hline TEPP (tetraethyl dithiopyrophosphate)"* & Liquid & 0.001 & 0.047 & & 1 & & 10 \\
\hline Terbufos"* & Liquid & 0.001 & & & 1 & & \\
\hline
\end{tabular}


CHEMICAL DAIA

\begin{tabular}{|c|c|c|c|c|c|c|c|}
\hline Chemical & Physical & Release & TLV & ERPG-3 & LOC & STEL & IDLH \\
\hline & \begin{tabular}{|l|} 
State \\
\end{tabular} & Factor & $(\mathrm{mg} / \mathrm{m} 3)$ & $(\mathrm{mg} / \mathrm{m} 3)$ & $(\mathrm{mg} / \mathrm{m} 3)$ & $(\mathrm{mg} / \mathrm{m} 3)$ & $(\mathrm{mg} / \mathrm{m} 3)$ \\
\hline Tetraethyl lead"* & Liquid & 0.001 & 0.1 & & 4 & & 40 \\
\hline Tetraethyl tin "* & Liquid & 0.001 & & & 7 & & \\
\hline Tetrafluorethylene" & Gas & 1 & & & & & \\
\hline Tetrafluorohydrazine* & Gas & 1 & 29 & & & 45 & \\
\hline Tetramethyl lead" & Liquid & 0.001 & 0.15 & & 4 & & 40 \\
\hline Tetranitromethane"* & Liquid & 0.001 & & & 8 & & \\
\hline Thallium (sol. cpds.) & Solid & 0.001 & & & & & 20 \\
\hline Thallic oxide & Solid & 0.001 & 0.1 & & 2 & & \\
\hline Thallous carbonate*" & Solid & 0.001 & 0.1 & & 2 & & \\
\hline Thallous chloride"* & Solid & 0.001 & 0.1 & & 2 & & \\
\hline Thallous Malonate"* & Solid & 0.001 & & & 2 & & \\
\hline Thallous sulfate ${ }^{* *}$ & Solid & 0.001 & 0.1 & & 2 & & \\
\hline Thallium sulfate** & Solid & 0.001 & 0.1 & & 2 & & \\
\hline Thiocarbazide"* & Solid & 0.001 & & & 100 & & \\
\hline Thiofanox ${ }^{* *}$ & Solid & 0.001 & & & 8.5 & & \\
\hline Thionazin"* & Liquid & 0.001 & & & 3.5 & & \\
\hline Thionyl chloride* & Liquid & 0.001 & & & & 4.9 & \\
\hline Thiophenol"* & Liquid & 0.001 & & & 1.4 & & \\
\hline Thiosemicarbazide** & Solid & 0.001 & & & 9.2 & & \\
\hline Thiourea, (2-chlorophenyl)"* & Solid & 0.001 & & & 4.6 & & \\
\hline Thiourea, (2-methylphenyl)** & Solid & 0.001 & & & 50 & & \\
\hline Titanium tetrachloride*" & Liquid & 0.001 & 0.05 & & 1 & & \\
\hline Toluene & Liquid & 0.001 & 377 & & & 565 & 7660 \\
\hline Toluene 2, 4-diisocyanate & Liquid & 0.001 & 0.036 & & 7 & 0.14 & 72.4 \\
\hline Toluene 2,6-diisocyanate"* & Liquid & 0.001 & & & 0.9 & & \\
\hline Trans-1,4-dichlorobutane** & Liquid & 0.001 & & & 4.4 & & \\
\hline Triamiphos"* & Solid & 0.001 & & & 10 & & \\
\hline Triazofos"* & Liquid & 0.001 & & & 2.8 & & \\
\hline Trichloroacetyl chloride"* & Liquid & 0.001 & & & 4.5 & & \\
\hline Trichloro (chloromethyl) silane ${ }^{*}$ & Liquid & 0.001 & & & 0.3 & & \\
\hline Trichloro (dichlorophenyl) silane" & Liquid & 0.001 & & & 8 & & \\
\hline Trichloroethylsilane*" & Liquid & 0.001 & & & 3 & & \\
\hline 1,1,1-Trichloroethane (Methyl chloroform) & Liquid & 0.001 & 1900 & & & 2450 & 5550 \\
\hline 1,1,2-Trichloroethane & Liquid & 0.001 & 55 & & & & 2775 \\
\hline Trichloroethylene (TCE) & Liquid & 0.001 & 269 & & & 1080 & 5460 \\
\hline Trichlorofluoromethane & Liquid & 0.001 & 5620 & & & & 57100 \\
\hline Trichlorosilane* & Liquid & 0.001 & & & & & \\
\hline Trifluorochloroethylene" & Gas & 1 & 5 & & & & \\
\hline Trichloronate"* & Liquid & 0.001 & & & 10 & & \\
\hline Trichlorophenylsilane"* & Liquid & 0.001 & & & 3.3 & & \\
\hline Triethoxysilane** & Liquid & 0.001 & & & 5 & & \\
\hline Trimethylehlorosilane"* & Liquid & 0.001 & & & 50 & & \\
\hline Trimethylolpropane phosphite** & Solid & 0.001 & & & 2.5 & & \\
\hline Trimethyhin chloride"* & Solid & 0.001 & & & 20 & & \\
\hline
\end{tabular}

" = Contained in Appendix A to 29 CFR 1910.119, " = Contained in Appendix A to 40 CFR 355

Page 11 
CHEMICAL DATA

\begin{tabular}{|c|c|c|c|c|c|c|c|}
\hline Chemical & Physical & Release & TLV & ERPG-3 & LOC & STEL & IDLH \\
\hline & State & Factor & $(\mathrm{mg} / \mathrm{m} 3)$ & $(\mathrm{mg} / \mathrm{m} 3)$ & $(\mathrm{mg} / \mathrm{m} 3)$ & $(\mathrm{mg} / \mathrm{m} 3)$ & $(\mathrm{mg} / \mathrm{m} 3)$ \\
\hline Triphenyltin chloride"* & Solid & 0.001 & & & 20 & & \\
\hline Trimethoxysilane" & Liquid & 0.001 & & & & & 625 \\
\hline Tris (2-chloroethyl) amine"* & Liquid & 0.001 & & & 0.8 & & \\
\hline Valinomycin"* & Solid & 0.001 & & & 2.5 & & \\
\hline Vanadium, as V2O5, pentoxide"* & Solid & 0.001 & 0.05 & & 7 & & 70 \\
\hline Vinyl acetate monomer"* & Liquid & 0.01 & 35 & & 54 & & \\
\hline Vinyl chloride & Gas & 1 & 2.6 & & & 13 & \\
\hline Wartarin"* & Solid & 0.001 & 0.1 & & 20 & & 350 \\
\hline Warfarin sodium"* & Solid & 0.001 & & & 9 & & \\
\hline Xylene & Liquid & 0.001 & 435 & & & 655 & 4410 \\
\hline Xylene dichloride"* & Solid & 0.001 & & & 2 & & \\
\hline Zinc, ZnO & Solid & 0.001 & 5 & & & 10 & \\
\hline Zine phosphide"* & Solid & 0.001 & & & 12 & & \\
\hline
\end{tabular}




\section{APPENDIX C}

DEFINITIONS FROM AIHA, OSHA, ACGIH, EPA AND NIOSH 


\section{AIHA EMERGENCY RESPONSE PLANNING GUIDELINES (ERPGs) FOR ON-SITE AND OFF-SITE EXPOSLRES TO ACUTELY HAZARDOUS MATERIALS}

The American Industrial Hygiene Association (AIHA) has established ERPGs for 12 compounds. ERPGs are emergency exposure limits based on insignificant, reversible, and irreversible health effects. Three levels of ERPGs have been established by AIHA:

1. ERPG-1 is the maximum airborne concentration below which it is believed that nearly all individuals could be exposed for up to 1 hour without experiencing other than $m$ ild transient adverse health effects or without perceiving a clearly defined objectionable odor.

Comment: These exposures are considered to have insignificant health consequences. Offsite airborne concentrations at or below ERPG-1 correspond to low consequence.

2. ERPG-2 is the maximum airborne concentration below which it is believed that nearly all individuals could be exposed for up to 1 hour without experiencing or developing irreversible or other serious health effects or symptoms which could impair an individual's ability to take protective action.

Comment: On-site airborne (worker) concentrations at 100 or above ERPG-2 correspond to moderate consequences.

3. ERPG-3 is the maximum airborne concentration below which it is believed that nearly all individuals could be exposed for up to 1 hour without experiencing or developing life-threatening health effects.

Comment: Exposures at or above the ERPG-3 level off-site correspond to a high consequence level. 


\section{DEFINITIONS FOR AMERICAN CONFERENCE OF GOVERNMENTAL INDUSTRIAL HYGIENISTS (ACGIH)}

\section{ACGIH}

ILV

Threshold limit values refer to airborne concentrations of substances and represent conditions under which it is believed that nearly all workers may be repeatedly exposed day after day without adverse effect. Because of wide variation in individual susceptibility, however, a small percentage may be affected more seriously by aggravation of a pre-existing condition or by development of an occupational illness.

Threshold umits are based on the best available information from industrial experience, from experimental human and animal studies, and, wher: possible, from a combination of the three. The basis on which the values are established may differ from substance to substance; protection against impairment of health may be a guiding factor for some, whereas reasonable freedom from irritation, narcosis, nuisance, or other forms of stress may form the basis for others.

For some substances, e.g., irritant gases, only one category, the ILV. Ceiling, may be relevant. For other substances, either two or three categories may be relevant, depending upon their physiological action. It is important to ohserve that if any one of these three TLVs is exceeded, a potential hazard from that substance is presumed to exist.

IIV TWA

The Threshold Limit Value-Time Weighed Average is the TWA concentration for a normal 8-hour workday and a 40-hour workweek to which nearly all workers maybe repeatedly exposed, day after day, without adverse effect.

STEL

A STEL is defined as a 15-minute TWA exposure which should not be exceeded at any time during a work day, even if the eight-hour-TWA is within the TLV. Exposures at the STEL should not be longer than 15 minutes and should not be repeated more than four times per day. There should be at least 60 minutes between successive exposures at the STEL. An averaging period other than 15 minutes may be recommended when this is warranted by observed biological effects. 


\section{DEFINITION FROM NATIONAL INSTITUTE OF \\ OCCUPATIONAL SAFETY AND HEALTH}

\section{NIOSH}

IDLH

The Immediately Dangerous to Life or Health level represents a maximum concentration from which one could escape within 30 minutes without any escapeimpairing symptoms or any irreversible health effects.

\section{DEFINITION FROM THE ENVIRONMENTAL PROTECTION AGENCY \\ EPA/FEMA/DOT}

LOC

Level of Concern concentrations are set by EPA/FEMA/DOT in their Technical Guidance for Hazards Analysis (EPA 1987) and are defined as those concentrations of an extremely hazardous substance in the air above which there may be serious irreversible health effects or death as a result of a single exposure for a relatively short period of time. Although this definition is comparable to that for the NIOSH IDLH, with the exception that the EPA indicates the possibility of irreversible health effects above these levels whereas the NIOSH indicates no irreversible health effects below IDLH levels, EPA typically sets LOC concentrations at one-tenth of the IDLH level. Therefore, in some instances, the LOC values may be considered overly conservative. 


\section{OSHA DEFINITIONS (29 CFR 1910.1000) FROM AIR CONTAMINANT STANDARDS}

Permissible Exposure Limit (PEL): An employee's exposure in any 8-hour work shift of a 40-hour work week, shall not exceed the 8-hour time weighted average given for that material in the Z-1 Table unless otherwise noted; a (C) designation denotes a ceiling limit.

Acceptable Ceiline Concentration: An employee's exposure to a material listed in Table Z-2 shall not exceed at any time during an 8-hour sift the acceptable ceiling concentration limit given for the material, except for a time period, and up to a concentration not exceeding the maximum duration and concentration allowed in the column under "acceptable maximum peak above the acceptable ceiling concentration for an 8-hour shift."

Time Weighted Average (TWA) is the employee's average airborne exposure in any 8-hour work shift of a 40-hour work week which shall not be exceeded.

Short-term Exposure Limit (STEL) is the employee's 15-minute time weighted average exposure which shall not be exceeded any time during a work day unless another time limit is specified in parenthetical notation below the limit. If another time period is specified, the time weighted average exposure over that time limit shall not be exceeded at any time during the working day.

Ceiling/" $C$ ". An employee's exposure to chemicals preceded by a " $C$ " shall at no time exceed the ceiling value given for that material. A ceiling value is the employee's exposure which shall not be exceeded during any part of the work day. If instantaneous monitoring is not feasible, the ceiling shall be assessed as a 15-minute time-weighedaverage exposure which shall not be exceeded at any time over a working day. 

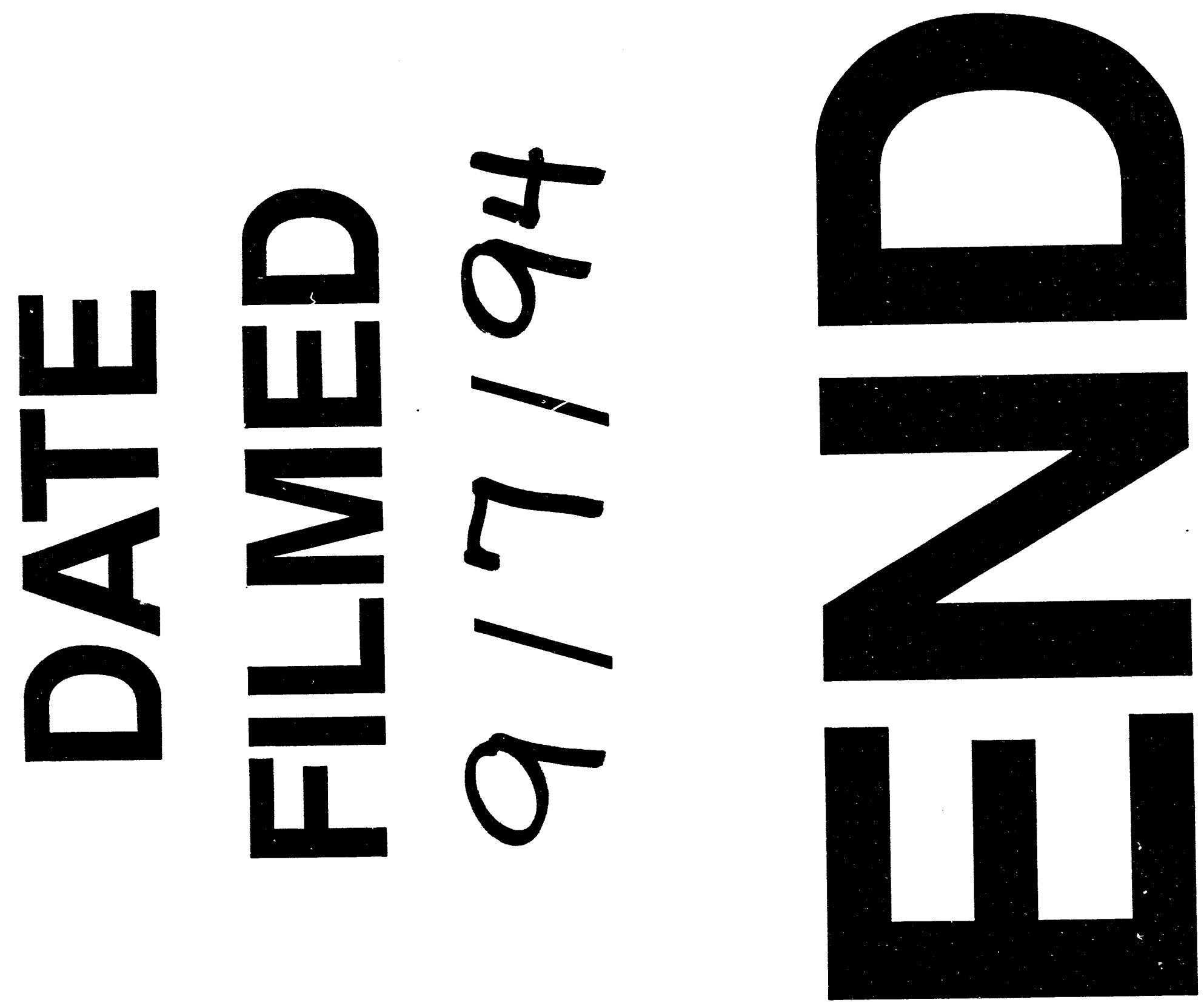
